\title{
Apoptosis and Necrosis in the Liver
}

\author{
Maria Eugenia Guicciardi ${ }^{1}$, Harmeet Malhi ${ }^{1}$, Justin L. Mott ${ }^{2}$, and Gregory J. Gores ${ }^{*}, 1$ \\ ${ }^{1}$ Division of Gastroenterology and Hepatology, College of Medicine, Mayo Clinic, Rochester, \\ Minnesota \\ ${ }^{2}$ Department of Biochemistry and Molecular Biology and Eppley Cancer Center, University of \\ Nebraska Medical Center, Omaha, Nebraska
}

\section{Abstract}

Because of its unique function and anatomical location, the liver is exposed to a multitude of toxins and xenobiotics, including medications and alcohol, as well as to infection by hepatotropic viruses, and therefore, is highly susceptible to tissue injury. Cell death in the liver occurs mainly by apoptosis or necrosis, with apoptosis also being the physiologic route to eliminate damaged or infected cells and to maintain tissue homeostasis. Liver cells, especially hepatocytes and cholangiocytes, are particularly susceptible to death receptor-mediated apoptosis, given the ubiquitous expression of the death receptors in the organ. In a quite unique way, death receptorinduced apoptosis in these cells is mediated by both mitochondrial and lysosomal permeabilization. Signaling between the endoplasmic reticulum and the mitochondria promotes hepatocyte apoptosis in response to excessive free fatty acid generation during the metabolic syndrome. These cell death pathways are partially regulated by microRNAs. Necrosis in the liver is generally associated with acute injury (i.e., ischemia/reperfusion injury) and has been long considered an unregulated process. Recently, a new form of "programmed" necrosis (named necroptosis) has been described: the role of necroptosis in the liver has yet to be explored. However, the minimal expression of a key player in this process in the liver suggests this form of cell death may be uncommon in liver diseases. Because apoptosis is a key feature of so many diseases of the liver, therapeutic modulation of liver cell death holds promise. An updated overview of these concepts is given in this article.

\section{Introduction}

A diverse set of metabolic, toxic, and inflammatory insults result in liver injury and disease. A common feature of these insults is activation of apoptotic and/or necrotic cell death. This review will focus on cell death of multiple liver cell types as it relates to liver pathology. Because of the surfeit of experimental data concerning apoptosis and necrosis in liver disease, this review will focus on these predominant modes of cell death. The subsequent sections of this work will discuss the experimental evidence for cytotoxic pathway activation and will review the molecular mechanisms whereby insult is translated into damage, and ultimately hepatobiliary disease.

The liver is somewhat unique in that even in the face of significant hepatic injury, there is frequently preservation of hepatic function-namely synthetic, metabolic, and secretory functions. Due to this partial separation of function and injury, a number of liver diseases are not initially discovered because of decreased liver function, but rather through evidence of increased liver injury. As a brief example, consider the patient with nonalcoholic fatty liver

(C) 2013 American Physiological Society.

*Correspondence to gores.gregory@ mayo.edu. 
disease, a growing health problem. Patients generally have maintained liver function with normal serum albumin, hemostasis, heme catabolism, and bile secretion. However, signs of liver disease are readily apparent by detection of released hepatocellular transaminases [serum alanine aminotransferase (ALT) and aspartate aminotransferase (AST)] into the serum, or by histologic examination of biopsied liver tissue which demonstrates a range of histologic changes including steatosis, inflammation, ballooned hepatocytes, Mallory-Denk bodies, apoptotic hepatocytes, and fibrosis or cirrhosis.

In Section "The Vulnerable Hepatocyte and Cholangiocyte," the structure and cell types of the liver are discussed with a focus on how liver structure and biological functions predispose cells to injury. This includes the delivery of ingested substances first to the liver via the portal circulation, as well as bile acid (BA) synthesis and toxicity, and the particular role of the innate immune system in liver damage.

Section "Models of Cell Death" covers in detail the signaling programs that communicate cell death to various cells of the liver. Activation of apoptosis can proceed by way of the extrinsic or death-receptor-associated pathways, as well as through the intrinsic or organellemediated pathways. The steps in cellular demise can be carried out in a caspase-dependent or caspase-independent manner. Next, unregulated and regulated hepatocyte necrosis is discussed, and the section is concluded with a discussion on the difficulty in distinguishing necrosis from apoptosis followed by secondary necrosis in vivo, and offers insights into how apoptosis can be an inflammation-inducing event in the liver.

Emerging pathways that regulate hepatobiliary cell death are introduced and detailed in Section "Unique Regulatory Platforms and Pathways." This section includes a review of the formation and function of the inflammasome, a signaling platform likely activated as part of the innate immune system, which can promote inflammation and injury. Regulation of liver cell death by microRNAs is then covered, including microRNA biogenesis and functions as well as the consequences of liver-specific loss of microRNAs. These regulatory pathways are conceptually integrated into liver damage.

A severe consequence of altered cell death, liver cancer, is discussed in Section "Apoptosis and Hepatobiliary Cancer." While liver functions can be preserved after years of ongoing liver injury, the remarkable ability of the liver to regenerate in response to chronic injury has a dark side, namely, the role of compensatory proliferation in the development of primary liver cancers. This section is devoted to the role of apoptosis in the initiation and progression of hepatobiliary cancer. The results may not be what you would expect.

Therapeutic Targets is a section devoted to the potential application of the knowledge gained studying cell death mechanisms. While specific treatment of the hepatotoxic agent is preferred, treatment strategies directed at preserving cell survival likely have a role in cases where the inciting agent is poorly targeted or is unknown. The molecular focus of this section is based on pathway mechanisms specified in this text, and we hope will serve to elevate the profile of these potential targets leading to innovative strategies to modulate well-recognized apoptosis regulators.

Research on liver injury continues to be a productive and heavily investigated endeavor, with over 7000 manuscripts indexed on Pubmed in 2011 alone. In this review, we discuss the molecular features of cell death, from activation to regulation to execution, and relate these to the biology of the liver. The unique anatomic, physiologic, and biochemical traits of the liver set the stage for a significant role for apoptosis in hepatobiliary pathology. 


\section{The Vulnerable Hepatocyte and Cholangiocyte}

The liver macroanatomy and microanatomy have evolved to serve a complex array of specialized functions. The functional repertoire of the liver encompasses vascular, metabolic, secretory, and immune functions. The liver has a dual blood supply, receiving through the portal vein venous return from the stomach, small intestine and large intestine, and receiving through the hepatic artery oxygenated blood from the aorta. The parenchymal cell population in the liver is comprised of hepatocytes. In addition, there are several nonparenchymal cells in the liver including cholangiocytes, liver sinusoidal endothelial cells (LSECs), hepatic stellate cells (HSCs), liver-resident macrophages known as Kupffer cells, natural killer (NK) cells and natural killer T (NKT) cells (332). Hepatocytes are organized into plates, forming bile canaliculi by their apical membranes. Hepatocyte plates are juxtaposed with hepatic sinusoids. This organization permits a large surface area of contact between hepatocytes and the blood flowing through the hepatic sinusoids. Hepatic sinusoids are lined by LSEC, a fenestrated endothelial cell (82). Kupffer cells are located within hepatic sinusoids (36). HSC are pericytes, thus surround LSEC, and upon activation transform into myofibroblasts. In the activated myofibroblast state they acquire a contractile function and also a fibrogenic function. Cholangiocytes are epithelial cells that line bile ducts. The cellular architecture and organization of these multitudinous cell types permits smooth execution of all of the livers' functions. It also imparts unique susceptibilities to injurious stimuli as well as several unique injury responses. In a broad and simplistic sense, the cell types that commonly sustain damage are LSEC, hepatocytes, and cholangiocytes, though examples can be found for injury to other cell types. Furthermore, cells of the innate and adaptive immune system are intimately involved in ongoing inflammation and injury in the liver.

Hepatocytes are the most numerous cell type in the liver and comprise most of the liver mass (278). Their myriad functions include the synthesis and secretion of plasma proteins, including albumin, the most abundant plasma protein, coagulation factors, and acute phase proteins. Hepatocytes function as nutritional rheostats, metabolizing and storing gut-derived nutrients, and generating glucose under conditions of starvation. Lipoproteins are synthesized and secreted by hepatocytes and they are also central to the regulation of lipid metabolism. Hepatocytes are the only cell type in the body that can synthesize bile acids (BAs) by de novo synthesis from cholesterol. They can also take up circulating BAs. BAs and other constituents of bile are vectorially secreted by hepatocytes leading to the formation of bile. Most xenobiotics are detoxified by hepatocytes, and along with detoxified endobiotics secreted into bile. Each of these functional specializations also imparts risk to the hepatocyte. Hepatocytes can be damaged from the synthesis and accumulation of mutant proteins, for example, alpha-1 antitrypsin. Due to a central role in metabolism, hepatocytes are targeted in disorders of nutritional excess, for example, nonalcoholic steatohepatitis. BAs that accumulate in cholestasis are injurious to hepatocytes. Hepatocytes can be chronically infected by hepatotropic viruses which can cause chronic liver injury. Alcohol and drugs such as acetaminophen (APAP) are metabolized and detoxified in the liver, and in excess can damage the liver. Hepatocytes are targeted in ischemia-reperfusion injury (IRI). Death of damaged hepatocytes is a feature of all of these disease states. The cytotoxic signaling pathways that mediate hepatocyte injury are conserved downstream of the inciting stimulus; however, there are unique stimulus-specific features. These signaling pathways are discussed in detail in other sections of this review. Death receptor-ligand signaling systems known to mediate hepatocyte death are Fas-FasL, death receptor 5 (DR5)-Tumor necrosis factor-related apoptosis-inducing ligand (TRAIL), and Tumor necrosis factor (TNF)-R1TNF-a (vide infra), though TNF-a primarily mediates inflammation. 
Cholangiocytes are biliary epithelial cells which line the intrahepatic and extrahepatic bile ducts. They are targeted by a host of diseases grouped altogether into cholangiopathies. Cholangiocarcinoma (CCA), a chronic inflammation-associated malignancy also arises in cholangiocytes. Cholestasis occurs when bile flow is impaired. It is characterized by accumulation of toxic bile salts within the liver. Biliary proliferation, termed ductular reaction occurs in cholestasis and other cholangiopathies (217). Biliary epithelial apoptosis is also enhanced in cholestasis, and it increases further as cholestasis resolves.

Cholangiocytes are damaged by IRI (268). Though they are resistant to anoxia, during the reperfusion phase of injury, they are more susceptible than hepatocytes to cell death. Primary biliary cirrhosis (PBC) is characterized by immune-mediated intrahepatic bile duct destruction. Cholangiocyte apoptosis is increased several fold in liver biopsy samples from patients with PBC (145). This increase in apoptosis is associated with an accumulation of FasL expressing mononuclear cells around the bile ducts and enhanced Fas expression in bile ducts (3). The biliary pathogen Cryptosporidium parvum induced Fas-dependent apoptosis in a cholangiocyte cell line (69). Besides Fas, CD40, a death receptor belonging to the TNF family, and its ligand CD154 mediate cholangiocyte apoptosis in vitro (6). CD40 expression is also increased in bile ducts in PBC (3). TRAIL receptor 2/DR5 is expressed by murine cholangiocytes (333). Activation of DR5 by an agonistic antibody leads to cholangiocyte apoptosis, which leads to the development of cholangitis (333). DR5 expression is also enhanced in biliary epithelia in cholestatic liver diseases such as PBC and primary sclerosing cholangitis (PSC). Thus, apoptosis of the epithelial cells of the liver, both hepatocytes and cholangiocytes, is an important feature of the diseases that target these cell types.

\section{Portal blood flow and toxic xenobiotics}

The portal vein brings to the liver venous return from the splenic, superior mesenteric vein, inferior mesenteric, gastric, and cystic veins. Portal blood flow comprises $75 \%$ to $85 \%$ of hepatic blood supply, and is large in volume with the liver receiving $25 \%$ to $30 \%$ of resting cardiac output. Thus the liver receives all digested and absorbed nutrients, reabsorbed bile salts, absorbed microbial products, ingested drugs, and other xenobiotics in high concentrations. This forms the basis of first pass metabolism leading to lower levels of xenobiotics in the systemic circulation than in the portal circulation. Many endobiotics are synthesized and metabolized in the liver. Most xenobiotics are detoxified by hepatocytes, and along with detoxified endobiotics secreted into bile. Phase I biotransformation reactions, including those catalyzed by the cytochrome $\mathrm{P} 450$ superfamily of monooxygenases, convert xenobiotics to polar compounds (114). Phase II reactions conjugate these polar metabolites to glucuronic acid, sulfate, glutathione, glycine, or taurine (171). In Phase III reactions, these conjugated metabolites are transported into bile by specific transporters (191). All of these enzymes have broad substrate specificity and functional redundancy allowing the liver to metabolize a wide variety of xenobiotics. These reactions mostly detoxify xenobiotics; however, in some instances can form reactive intermediates or activate xenobiotics to a toxic form (315). Ethanol and APAP are the two most well recognized xenobiotics with significant liver toxicity. Other ingested drugs can induce predictable or idiosyncratic liver injury, which may be metabolic or immune-mediated in mechanism (360).

Ethanol-induced liver disease is seen among heavy consumers of alcohol. It is the leading cause of liver disease in many societies. Though many cellular signaling pathways activated by ethanol have been elucidated, and it is known that ethanol activates the innate immune system in the liver, the specific factors that impart risk to a subset of heavy drinkers who develop progressive disease are unclear. Ethanol increases the production of reactive oxygen species (ROS) via induction of the phase I enzyme CYP2E1 (29). Though CYPE2E1 is a minor pathway for ethanol metabolism, it is induced by ethanol, generates ROS, and 
oxidative damage to cellular constituents occurs with acute and chronic ethanol ingestion. Ethanol metabolism by CYP2E1 can have complex interactions with other xenobiotics, for example, APAP, the toxicity of which is mitigated by a concurrent acute ingestion of ethanol (384). On the other hand, chronic administration of ethanol induces CYP2E1, thus increasing the metabolism of other CYP2E1 targets, which may sensitize to APAP toxicity (8). Hepatocyte cytotoxicity including apoptosis is a feature of ethanol-induced liver injury in experimental models (296). Activation of multiple cell death pathways by ethanol is highlighted in this study by the observation that even when hepatocyte apoptosis is blocked, markers of other death pathways, liver injury, and inflammatory pathways are still activated in ethanol-fed mice (296). The innate immune system, Kupffer cells in particular, are activated in models of ethanol-induced liver injury (158). TNF- $a$ and interleukin-6 are derived from activated Kupffer cells (73). The complement cascade, a soluble mediator of innate immune responses, is also activated, likely by hepatocyte death, and further activates inflammatory pathways (73).

APAP overdose induces predictable, dose-dependent liver injury, and is the leading cause of drug-induced acute liver failure (64). Therapeutic doses of APAP are metabolized primarily by conjugation with glucuronic acid or sulfate moieties. A small percentage is oxidized by the cytochrome $\mathrm{P} 450$ pathway to a toxic metabolite, $N$-acetyl- $p$-benzoquinone imine (NAPQI). Normally, NAPQI is rapidly conjugated to intracellular glutathione leading to the formation of a nontoxic conjugate. However, under conditions of APAP excess, glutathione depletion occurs and NAPQI accumulates. NAPQI covalently and indiscriminately binds to cysteine moieties on proteins, thus interfering globally with hepatocyte function.

Glutathione replacement with $N$-acetyl cysteine (NAC) prevents liver injury and failure if given in a therapeutic window soon after the ingestion. However, delayed administration of NAC is ineffective in preventing toxicity. Formation of ROS, mitochondrial dysfunction, activation of the stress kinase, c-jun N-terminal kinase (JNK), hepatocyte apoptosis, and necrosis occur in models of APAP toxicity $(135,141,197)$. Though the predominant endpoint morphology recognized in models of APAP toxicity is of necrotic cell death, several studies underscore the activation and involvement of apoptotic signaling pathways in APAP-induced cell death. The proapoptotic Bcl-2 protein Bim and death ligand TRAIL are induced by APAP, and Bim-deficient mice are partially protected from APAP-induced liver injury (12). Moreover, using an antisense oligonucleotide to Fas abrogates APAP-induced liver injury and apoptosis (401). While the metabolism of APAP is clear and the known cellular effects are multiple, the exact pathways that result in liver injury and inflammation are less well defined. Activation of the innate immune system has been a well-recognized feature of APAP toxicity $(37,168,232)$. The data suggest that inflammatory responses to APAP vary by strain of mice; moreover, dose of APAP used and even the presence of the solvent dimethyl sulfoxide (DMSO) play a role in the activation of hepatic NKT cells (168, 232, 244). Recent studies have further elucidated the mechanisms by which APAP might trigger an inflammatory response. In these rodent studies, APAP-induced cell death led to the release of endogenous damage-associated molecular patterns (DAMPs), high-mobility group box-1 (HMGB-1), and apoptotic DNA $(67,167)$. Toll-like receptor (TLR)-9 was activated by APAP-induced DAMPs leading to increased expression of the precursor forms of the proinflammatory cytokines interleukin-1 $\beta$ (IL-1 $\beta$ ) and interleukin-18 (IL-18). The Nalp3 inflammasome was also activated by APAP, leading to enhanced proteolytic cleavage of the precursors to mature IL-1 $\beta$ and IL-18 (167). In a complementary study using APAPinduced liver injury, it was demonstrated that two proteins, CD24 and Siglec-C, bind to HMGB-1, thus preventing the activation of downstream signaling events and mitigating the inflammatory response (67). Similar studies by others failed to recapitulate these findings $(379,380)$, although it should be noted that in the later studies a lower dose of APAP (300 $\mathrm{mg} / \mathrm{Kg}$ ) was injected in mice from the same genetic background. However, survival is an incontrovertible end point, and mice deficient in caspase 1 or the inflammasome 
components, Nalp3 or ASC, demonstrated a survival advantage upon APAP challenge. Therefore, additional studies are needed to elucidate the relative contribution of each cell type of the innate immune system and of the signaling pathways in the pathogenesis of APAP-induced liver injury.

\section{Bile formation and toxicity}

Bile formation is an essential function of the liver. Bile not only contains elements required for digestion and absorption of dietary lipids and fat-soluble vitamins, but also provides an efficient route for elimination of lipophilic toxins and xenobiotics, as well as endogenous substances such as bilirubin, BAs, and cholesterol. Bile is formed mainly within the hepatocytes and secreted into the bile canaliculi. It is subsequently modified during the passage in the biliary tree through reabsorption and secretion of fluid and solutes by the cholangiocytes lining the bile ducts, and eventually discharged into the duodenum. The predominant organic components of the bile, the BAs, are end products of hepatic cholesterol metabolism. Primary BA (cholic acid-CA and chenodeoxycholic acidCDCA) are synthesized by the hepatocytes, conjugated to either taurine or glycine, and secreted into the bile via the bile salt export pump (BSEP), whereas secondary BA (deoxycholic acid-DCA and lithocholic acid-LCA) are generated by transformation of the primary BA by the intestinal bacteria. The majority of the BA pool is reabsorbed in the terminal ileum and returns to the liver through the portal vein, where it is reexcreted into the bile after uptake by the sodium $\left(\mathrm{Na}^{+}\right)$-taurocholate cotransporter protein (NTCP) on the basolateral membrane of the hepatocyte (347). Given their intrinsic toxicity, intracellular BA concentration is physiologically regulated by several transcriptional factors and nuclear receptors, in particular, farnesoid X receptor (FXR), which directly binds the BA and modulates the expression of a number of genes encoding BA transporters and enzymes involved in BA metabolism (237). However, pathologic conditions associated with impaired bile formation and excretion, referred to as cholestatic diseases, result in increased BA concentration in the systemic blood and accumulation of BA in the liver tissue with consequent hepatocellular damage. Although other potentially toxic bile components, as well as cholestasis-associated inflammatory cytokines and ROS, can also contribute to the liver damage associated with cholestasis, compelling clinical and experimental evidence demonstrate a primary role of BA-induced hepatotoxicity in this disease. A notable example is provided by progressive familial intrahepatic cholestasis (PFIC), a class of chronic cholestatic disorders affecting mainly pediatric patients and characterized by inherited defects in genes regulating biliary epithelial transporters. Patients with PFIC type 2 (PFIC-2) carry mutations in the gene $A B C B 11$ encoding BSEP, which results in impaired BA excretion into the bile and severe cholestasis with bile duct proliferation $(326,327)$. Patients with PFIC type 3 (PFIC-3) show deficiencies in hepatocellular phospholipid export as a result of mutations in the MDR3 gene. The multidrug resistance (MDR) protein MDR3 is required for translocation of phosphatidylcholine from the inner to the outer leaflet of the canalicular membrane, a process necessary to protect the membranes of the intrahepatic bile ducts against the toxic effect of BA (90). Mutations in MDR3 result in the inability to secrete phospholipids and subsequent BA-induced hepatocyte damage (78). A similar phenotype is also observed in $m d r 2$ deficient mice, the murine ortholog of $M D R 3(78,79)$. Finally, FXR knockout mice show elevated serum BA, and undergo massive hepatocyte apoptosis and severe liver damage following administration of a cholic acid-enriched diet due to their inability to regulate BA homeostasis, as opposed to wild-type mice who respond to the same diet by increasing BA excretion into the bile (via upregulation of BSEP and MDR3), decreasing BA uptake (via downregulation of NTCP), and inhibiting BA neosynthesis (via downregulation of the rate-limiting enzyme of BA biosynthesis, cholesterol 7a-hydroxylase) (320). 
BA-induced hepatocyte apoptosis is a common pathologic feature of cholestatic liver diseases (128). Their toxicity is closely related to their hydrophobicity, with hydrophobic BA being more toxic than hydrophilic ones, as well as their conjugation to either taurine (less toxic) or glycine (more toxic). Hydrophobic BA, such as the glycine-conjugated form of CDCA (GCDCA), in concentrations comparable to those reached within the hepatocyte during cholestasis, have been shown to induce hepatocyte apoptosis in vitro by promoting ligand-independent oligomerization of the death receptor Fas/CD95 (26, 94, 118, 146, 254, $297,338,391$ ). The signaling cascade triggered by this event leads to the activation of several intracellular caspases which contribute to cellular demise (see Section "Extrinsic apoptosis by death receptors"). Accumulation of BA within the cell is an essential requirement to induce apoptosis, as cells unable to uptake BA are resistant to BA-induced apoptosis $(127,346)$. Indeed, intracellular BA accumulation promotes translocation of the Fas/CD95 receptor from the Golgi compartment, where it is stored, to the plasma membrane, where the increased density facilitates its spontaneous oligomerization and activation (322). Consistently, Fas-deficient (lpr) mice show reduced caspase activation and hepatocyte apoptosis compared to wild-type following bile duct-ligation (BDL), an established model of extrahepatic cholestasis $(146,254)$. BA modulation of death receptor signaling is not limited to activation of Fas, but also includes upregulation of DR5 (also known as TRAIL-R2), which sensitizes the hepatocytes to the cytotoxic effect of its cognate ligand TRAIL $(151,152)$, and inhibition of cFLIP, an antiapoptotic protein regulating death receptor function (153). Indeed, prolonged bile duct ligation can eventually cause liver injury even in the absence of Fas, despite the initial absence of damage, suggesting that other mechanisms are also involved (254). Moreover, GCDCA has been shown to induce apoptosis in Fas-deficient hepatocarcinoma cell lines, presumably by directly engaging the mitochondrial pathway (298).

Interestingly, BDL mice also display elevated serum ALT levels and areas of necrotic tissue (bile infarcts), indicating that necrosis also occurs in cholestasis. Although it is rather widely accepted that selected BA induce apoptosis in cell culture, which form of cell death (apoptosis vs. necrosis) would be prominent in vivo in cholestatic animals it is still somehow controversial and certainly more challenging to establish. Several reports questioned the hypothesis that apoptosis is the main trigger of liver injury in cholestasis, citing evidence of extensive necrosis and/or oncosis (oncotic necrosis) with limited apoptotic cell death in the liver of BDL rodents $(104,134,253,263,304)$. Part of the problem in identifying apoptotic cells in vivo resides in the ability of macrophages and Kupffer cells (and even hepatocytes themselves) to quickly and efficiently remove the apoptotic bodies, so that the amount of apoptotic cells in a liver specimen at any given time is always relatively low. In addition, if the engulfing capacity of the macrophages is overwhelmed by excessive apoptosis, the remaining apoptotic bodies will eventually undergo secondary necrosis, which shares many morphological features with primary necrosis (204). The absence of well-established markers to identify necrotic cells in vivo and the relatively low specificity of one of the most commonly used assay to detect apoptotic cells (Terminal deoxynucleotidyl transferase dUTP nick end labeling-TUNEL assay) also render this distinction quite difficult. It certainly cannot be excluded that primary necrosis may be triggered in cholestasis either directly by $\mathrm{BA}$, or, perhaps more likely, by the inflammatory cytokines produced during the disease. However, since both serum AST levels and bile infarcts are markedly reduced in BDL lpr mice and in wild-type mice simultaneously treated with a pancaspase inhibitor, together with improved animal survival, it seems likely that necrosis may be a secondary event following apoptosis $(53,134,254)$.

On the other hand, less detergent and/or more hydrophilic BA have been shown to simultaneously activate apoptotic and cytoprotective pathways, suggesting the severity of liver damage in cholestasis is likely determined by the balance between pro- and 
antiapoptotic signals $(297,346)$ (Fig. 1). For example, the tauro-conjugate of CDCA (TCDCA) stimulates phosphatidylinositol 3-kinase (PI3K) and blocks Fas-mediated apoptosis by preventing caspase 8 activation and translocation of Bid to the mitochondria $(297,338)$. In addition, TCDCA activates nuclear factor kappa B (NF- $\kappa B)$ in a PI3K- and PKCzeta-dependent manner, promoting the transcription of antiapoptotic genes (297). The hydrophilic BA ursodeoxycholic acid (UDCA) and its tauro-conjugate (TUDCA) protect from DCA-induced apoptosis by maintaining the mitochondrial transmembrane potential, inhibiting mitochondrial permeability transition (MPT), and preventing translocation of Bax to the mitochondria $(293,294)$. Notably, UDCA and TUDCA have become the treatment of choice in cholestatic hepatopathies thanks to their ability to inhibit hydrophobic BA-induced apoptosis, improve hepatobiliary secretion, and limit the immune response $(9,103,236$, 295). Several preclinical studies also suggested FXR agonists may be useful in the treatment of cholestatic liver disease. For example, treatment with the synthetic FXR agonist GW4064 significantly reduced serum lactate dehydrogenase and transaminase levels, and decreased inflammation, bile duct proliferation, and necrotic liver damage in cholestatic rats (231). Also, the synthetic analog of CDCA, 6a-ethyl-CDCA (6-ECDCA) promoted bile flow and protected against acute liver injury in a rat model of LCA-induced cholestasis (277). 6ECDCA is currently under development for treatment of cholestatic liver diseases including PBC; a phase II clinical trial showed that 6E-CDCA effectively reduced alkaline phosphatase levels in PBC patients; however, potential side effects, such as exacerbated pruritus and increased LDL, might limit the development and use of these drugs (106).

\section{Innate immune system}

The innate immune system in the liver is comprised of the liver resident macrophages Kupffer cells, dendritic cells, NK cells, and NKT cells $(36,85,225,301,308,314)$. In addition to these cell types, innate immune functions are also ascribed to hepatocytes, LSEC, HSC, and cholangiocytes $(83,95,363,382)$. Besides the barrier and surveillance functions of the intestinal innate immune system, the liver is the next line of defense toward a vast array of gut-derived endobiotics, xenobiotics, and bacterial products (111). This has led to the evolution of a very particular innate immune system in the liver. It is characterized by tolerance toward a vast array of self and nonself antigens (344). This tolerance permits concurrent solid organ transplantation and transplantation across MHC barriers. On the other hand, the establishment of chronic viral hepatitis is facilitated by the permissive immune tolerant state of the liver (281). While these conditions are characterized by the lack of effective protective immunity, another feature of nonmicrobial acute and chronic liver diseases is activation of the innate immune system, termed sterile inflammation (66). Though the innate immune system facilitates both inflammation and tissue healing in acute hepatitis, in chronic liver diseases, its chronic activation likely forms the basis for chronic inflammation (Fig. 2).

Rather than specific, antigen-based activation, the innate immune system is activated by conserved molecular patterns termed pathogen associated molecular patterns (PAMPs) when microbially derived and DAMPs when endogenous in origin (234). PAMP-based recognition and activation of innate immune cells imparts the ability to respond to a vast array of microbes in a rapid manner without the need for antigen processing and presentation. Similarly, in sterile inflammatory disorders DAMP-based recognition and activation of the innate immune system occurs. PAMPs and DAMPs are recognized by an array of cell surface or intracellular receptors termed pattern recognition receptors (PRRs), of which five major classes have been identified (Fig. 3). These are TLRs, nucleotide oligomerization domain (NOD)-like receptors (NLRs), RIG-I-like receptors (RLRs), C-type lectin receptors (CLRs), and absent in melanoma 2 (AIM2)-like receptors (19, 30, 337, 395). The activation of proinflammatory pathways downstream of PRR activation by either 
PAMPs or DAMPs results in transcriptional and translational upregulation of cytokines such as TNF- $\alpha$, interleukin-6, type I interferons, chemokines, complement proteins, acute phase proteins, and death ligands. DAMPs may be derived from intracellular constituents, such as uric acid, HMGB-1, heat shock protein 70 (HSP70), ATP, or matrix-derived such as hyaluronan. Classically, DAMPs are released from cells dying by necrosis. How apoptotic cell death may activate sterile inflammation is not well understood. In the present model, either secondary necrosis follows apoptosis resulting in release of DAMPs or massive apoptosis activates the sterile inflammatory response via, as yet, undefined pathways. In this context, it is known that the in vitro engulfment of apoptotic hepatocytes by Kupffer cells results in their activation and secretion of the death ligands TNF-a and FasL (54). Kupffer cells isolated from bile duct ligated mice, a model of cholestatic liver injury, also demonstrate increased expression of death ligands, similar to the in vitro findings.

The multifaceted involvement of the innate immune system in APAP-induced liver injury has been well described. Depletion of NK cells and NKT cells resulted in significant amelioration of liver injury in mice injected with APAP (232), although it should be noted these observations were obtained using DMSO to solubilize APAP. Markers of liver inflammation including FasL, interferon-gamma and several chemokines were reduced in the NK cell and NKT cell depletion group. Decreased liver inflammation resulted in improved survival of mice. Kupffer cells are activated in APAP-induced liver injury (242). This is likely due to release of DAMPs, including HMGB-1 and HSP70 from dead hepatocytes. DNA from apoptotic hepatocytes can also activate TLR9 leading to increased transcription of proinflammatory cytokines pro-IL-1 $\beta$ and prointerleukin 18 (IL-18) (167) (Fig. 3). Independently, via activation of the NLRP3 inflammasome, caspase-1 activity is increased, leading to increased processing of pro-IL-1 $\beta$ and pro-IL-18 by proteolytic cleavage to their active forms. Endogenous modifiers of DAMP exposure to innate immune cells also exist to keep inflammation in check. In APAP-induced liver injury CD24 and Siglec-10 (human) or Siglec-G (mice) bind to HMGB-1, thus blocking its engagement with PRRs (67). This response is specific to DAMPs as the inflammatory response and lethality of lipopolysaccharide were not modulated by CD24 or Siglec-G proteins.

Besides APAP-induced liver injury described above, chronic activation of the innate immune system with inflammation is a feature of nonalcoholic steatohepatitis (NASH) (10). Intrahepatic macrophages are increased in patients with NASH and correlate with severity of histologic activity (77). Experimental models suggest a role for both cholesterol and palmitic acid in activating Kupffer cells or macrophages in type II diabetes, respectively $(34,88)$. Inhibition of recruitment of circulating monocytes into the liver in steatohepatitis results in dampened inflammation (13). NKT cell depletion was observed in the liver in NASH (123); however, it is not clear how this may promote steatohepatitis. Inflammatory cytokines and chemokines are elevated in alcoholic steatohepatitis, and alcohol modulates many aspects of the innate immune system, depending on duration and extent of exposure. In experimental models, it can activate TLR4 and complement and inhibit NK cells (112). Overall, alcohol use impairs systemic innate and adaptive immune responses $(213,330)$.

\section{Models of Liver Cell Death}

\section{Apoptosis: Definitions, concepts, and relevance in the liver}

Cell death in the liver occurs mainly by apoptosis or necrosis, although other forms of cell death may occasionally occur $(181,182)$. Apoptosis is morphologically characterized by chromatin condensation and marginalization, DNA fragmentation, plasma membrane blebbing, cell shrinkage, and ultimately cell fragmentation into membrane-bound, organellecontaining bodies named apoptotic bodies (385). The apoptotic bodies are eventually recognized and eliminated by phagocytosis by macrophages or other neighboring cells. 
Biochemically, apoptosis is accompanied by events such as externalization of phosphatidylserine on the outer leaflet of the plasma membrane, increased mitochondrial membrane permeability with subsequent release of proteins normally residing in the intermembrane space, and activation of a family of cysteine proteases named caspases. Apoptosis is responsible for the physiological removal of unwanted cells, such as damaged or senescent cells, in mature tissues, as well as tissue remodeling during development. By counterbalancing mitosis, apoptosis is paramount to ensure liver tissue homeostasis during normal cell turnover, and to control liver growth and regeneration. However, because of the low rates of cell turnover in the liver and the rapid elimination of the apoptotic bodies by engulfing cells, identification of apoptosis in vivo, especially under physiological conditions, may be difficult. In normal human and rat livers, apoptotic bodies have been identified preferentially in the perivenular area (zone 3$)(24,25)$. According to the proposed "streaming liver" model, in which new hepatocytes would originate in the periportal area (zone 1 and 2) and "stream" out toward the perivenular region (zone 3), older hepatocytes would be found in zone 3, explaining the higher rates of apoptosis in that region (399). This model, however, is controversial $(47,185)$. Nonetheless, the importance of apoptosis in regulating liver volume is demonstrated by several experimental observations. First, mice deficient in the death receptor Fas/CD95, a main mediator of apoptosis in the liver, display substantial liver hyperplasia (2). Second, regression of liver hyperplasia in different experimental models occurs by apoptosis $(50,74,119)$. And third, in two rat models of biliary epithelial cell hyperplasia, regression of abnormally proliferated bile ducts is achieved mainly by biliary epithelial cell apoptosis (31). Finally, apoptosis has also been shown to promote liver regeneration by releasing growth signals that stimulated the proliferation of progenitor cells. Indeed, mice lacking caspase 3 or caspase 7, two key executioners of apoptosis, show impaired liver regeneration (219).

The Nomenclature Committee on Cell Death has recently published new recommendations for a functional classification of cell death based on biochemical criteria rather than the previously used morphological characteristics (109). The need for a new systematic classification stemmed from the discovery that cell deaths with similar morphological phenotypes can result from rather different biochemical and functional events. Maintaining the old distinction between extrinsic apoptosis (death receptor-initiated) and intrinsic apoptosis (caused by intracellular stress), the new guidelines now further distinguish between caspase-dependent and caspase-independent intrinsic apoptosis. This distinction is mainly done based on the ability of caspase inhibitors to block cell death once the mitochondria are permeabilized. In the liver, the intrinsic and extrinsic pathways of apoptosis intersect through the caspase 8-mediated cleavage of the proapoptotic Bcl-2 family member Bid (129).

\section{Extrinsic apoptosis by death receptors}

The extrinsic pathway of apoptosis (or extrinsic apoptosis) refers to a signaling pathway triggered by the binding of a specific class of transmembrane receptors (named death receptors) to their cognate ligands. Death receptors include Fas (also known as CD95), TNFa-receptor 1 (TNF-R1) and death receptor 4 and 5 (DR4 and DR5, also known as TRAILR1 and TRAIL-R2, respectively), all of which are ubiquitously expressed in the liver to various extents (93). Their ligands (FasL/CD95L, TNF-a, and TRAIL) are mainly expressed by cells of the immune system and play a fundamental role in the elimination of virally infected, transformed, or damaged hepatocytes. Indeed, apoptosis in the liver is largely mediated by death receptors in disease states $(5,89,129,238,302,303,305,393,396)$. Binding of the receptor to its ligand results in recruitment of several adaptor proteins and initiator procaspases 8 and 10 to form a large multiprotein complex (referred to as deathinducing signaling complex or DISC). The DISC provides a platform for dimerization and 
activation of caspase 8 and caspase 10 . Active caspase $8 / 10$ then start a proteolytic cascade, culminating in the activation of the effector caspases, caspase 3,6, and 7, and ultimately cleavage and degradation of cellular proteins leading to cell death. In cells that utilize the socalled type I death receptor signaling (i.e., lymphocytes), the activation of effector caspases occurs by direct cleavage from the initiator caspases, whereas in cells that rely on type II signaling (i.e., hepatocytes, cholangiocytes) effector caspases are activated after mitochondrial outer membrane permeabilization (MOMP) and release of mitochondrial proapoptogenic factors, such as cytochrome $c$ and second mitochondrial activator of caspases/direct IAP binding protein with low PI (SMAC/DIABLO) (130). Mediating the mitochondrial dysfunction is the cleavage of the $\mathrm{BH} 3$-only protein $\mathrm{Bid}$ by caspase 8 , which generates a truncated fragment (tBid) that translocates to the mitochondria and cooperates with the proapoptotic Bcl-2 proteins Bax and Bak to induce MOMP (Fig. 4). Cytochrome $c$ binds to apoptotic protease activating factor 1 (Apaf-1) and procaspase 9 in a complex termed the apoptosome, which facilitates caspase 9 activation and subsequent activation of the effector caspases. At the same time, SMAC/DIABLO binds and neutralizes the Xchromosome linked inhibitor of apoptosis protein (XIAP), an endogenous inhibitor of effector caspases, allowing the apoptotic cascade to proceed (Fig. 5). As some of our recent publications have extensively covered this topic, the reader is referred elsewhere for a more detailed description of the signaling pathways activated by death receptors $(130,239,394)$.

Hepatocytes have been regarded as type II cells based on the initial observation that Bid $^{-/-}$ mice were resistant to hepatocyte apoptosis and fulminant liver injury following injection of an agonistic antibody against Fas, suggesting mitochondria are required for Fas-induced apoptosis in the liver (394). Since then, countless reports have confirmed these results both in vivo and in vitro. Interestingly, recent studies have challenged this classification, suggesting that the strength of the Fas signal is really what determines whether hepatocytes act as type I or type II cells. Indeed, using a new hexameric form of soluble FasL, which provides a significantly stronger signal than commonly used agonistic antibodies and soluble cross-linked FLAG-FasL, the authors were able to induce hepatocyte apoptosis and liver failure in $\mathrm{Bid}^{-/-}$mice through a typical type I cell signaling (306). Therefore, it appears that weaker Fas stimulation would require activation of Bid and mitochondria dysfunction to achieve sufficient caspase activation (type II signaling), whereas stronger Fas stimulation would result in direct activation of effector caspases by caspase 8 (type I signaling). In the latter instance, Bid would only amplify the apoptotic signal. Borner and colleagues also demonstrated that cultured primary hepatocytes do not require Bid for FasL-mediated apoptosis (367). These observations can be reconciled with previous studies demonstrating that activation of the mitochondrial pathway following stimulation with soluble cross-linked FLAG-FasL (a "weak" signal) is necessary to overcome the resistance conferred by XIAP in hepatocytes, and that inhibition of XIAP can switch Fas-induced apoptosis from type II to type I (176).

Recently, there has been a renewed interest in the IAP family of proteins and their role in death receptor signaling. The mammalian IAPs, cellular IAP 1 and 2 (cIAP1 and cIAP2), and XIAP, regulate cell survival by means of their ability to ubiquitinate different cellular substrates and to bind and inhibit effector caspases (139). In particular, cIAP1 and cIAP2 contribute to the formation of an ubiquitin-dependent signaling complex in response to TNF- $a$ that modulates the activation of the transcription factor $N F-\kappa B$, therefore, controlling the expression of several antiapoptotic genes (358), while XIAP is a potent caspase inhibitor acting downstream of mitochondria (87). Overexpression of IAPs, a common feature of cancer cells, is associated with increased resistance to apoptosis by chemotherapeutic drugs and death receptor agonists (164); conversely, inhibition of IAPs often restores cancer cell sensitivity to apoptosis $(209,364)$. Hepatobiliary cancer cells are generally resistant to the death ligand TRAIL, due to the overexpression of antiapoptotic proteins. We have recently 
shown that cIAP1 inhibition, either by genetic manipulations or by using a small molecule mimicking the IAP-binding domain of SMAC that induces rapid cIAP1 degradation, sensitizes hepatocellular carcinoma cell lines to TRAIL-induced apoptosis, demonstrating that cIAPs play a crucial role in the regulation of TRAIL signaling (133). In addition to cIAP1, inhibition of XIAP also restores TRAIL sensitivity in CCA cells. In cholangiocytes, TRAIL induces apoptosis via a mitochondria-dependent pathway (type II), which is frequently inhibited in CCA cells due to the overexpression of the antiapoptotic Bcl-2 protein Mcl-1 (341). Downregulation of XIAP converts TRAIL signaling from type II to type I signaling, bypassing the mitochondria, and therefore, overcoming the Mcl-1 block (206). Similarly, hepatocytes undergo Fas-induced apoptosis independent of Bid and mitochondria dysfunction when XIAP is genetically deleted or pharmacologically inhibited (176). As both TRAIL agonists and SMAC mimetics have recently been developed and have entered clinical trials for some human malignancies, these data would suggest that the use of these two agents in combination may be beneficial in the treatment of hepatobiliary cancers. However, since the SMAC mimetics have been shown to increase hepatocyte sensitivity to Fas, the use of these compounds in patients with underlying liver conditions calls for caution (176).

Another interesting regulator of death receptor signaling is cellular FADD-like IL-1betaconverting enzyme (FLICE) inhibitory protein (cFLIP), in particular, its long isoform cFLIP $_{\mathrm{L}}$. cFLIP $\mathrm{L}_{\mathrm{L}}$ shares close structural homology with caspase 8 , but, unlike caspase 8 , has no catalytic activity due to the absence of a cysteine in the catalytic motif. The different isoforms of cFLIP have been long believed to be inhibitors of death receptor-mediated apoptosis due to their ability to compete with caspase 8 in binding to the adaptor Fasassociated protein with death domain (FADD), therefore, preventing caspase 8 homodimerization and activation. Indeed, heterodimerization of $\mathrm{cFLIP}_{\mathrm{L}}$ with caspase 8 does occur in the DISC in response to death receptor stimulation; however, this heterodimerization does not prevent caspase 8 activation, stirring a controversy on whether cFLIP $_{\mathrm{L}}$ is proor antiapoptotic $(39,252)$. Recent studies have now demonstrated that the $\operatorname{cFLIP}_{\mathrm{L}}$ :caspase 8 heterodimer has a different substrate specificity than the caspase 8:caspase 8 homodimer, and is involved in executing the nonapoptotic functions of caspase- 8 , specifically, the inhibition of receptor interacting kinase-3 (RIPK or RIP-3)-dependent necrosis $(163,272)$. Therefore, cFLIP $_{\mathrm{L}}$ acts as a switch to convert caspase 8 from a proapoptotic molecule into an antinecrotic one. This antinecrotic function of caspase 8 is essential during development, as $\operatorname{Casp}^{{ }^{-1-}}$ mice die at embryonic day E10.5 due to extensive TNF-a-mediated, RIPK3-dependent necrosis of endothelial, cardiac, and hematopoietic cells $(180,272,359)$. Likewise, $c F_{i j}{ }^{-1-}$ mice display a similar phenotype and die at the same stage of embryonic development (390). In the liver, where RIPK3 is expressed at minimal levels (329), cFLIP $\mathrm{L}_{\mathrm{L}}$ exerts its antiapoptotic effect by preventing death receptor-induced caspase 8 homodimerization, as well as by activating NF- $\kappa \mathrm{B}$ and Mitogenactivated protein kinases (MAPK) pathways $(124,275)$. Overexpression of $\mathrm{cFLIP}_{\mathrm{L}}$ is frequently observed in human hepatocellular carcinoma cell lines, and correlates with resistance to death receptor-mediated apoptosis (275). Downregulation of $\mathrm{cFLIP}_{\mathrm{L}}$ often restores the sensitivity to death receptor-mediated apoptosis $(110,124)$.

\section{Intrinsic apoptosis by organelle dysfunction}

The intrinsic pathway of apoptosis (or intrinsic apoptosis) can be triggered by a variety of intracellular stress inducers, including DNA damage, oxidative stress, UV and $\gamma$-irradiation, toxins, growth factor deprivation, and endoplasmic reticulum (ER) stress. Regardless of the nature of the initiating stimulus or the intracellular organelle where they may originate, all these intracellular signaling cascades ultimately converge at the mitochondria, resulting in mitochondrial dysfunction and MOMP. 


\section{Mitochondria}

The intrinsic pathway of apoptosis is tightly regulated by the Bcl-2 family of proteins, which act both upstream and at the level of the mitochondria to integrate death and survival signals $(75,397)$. The Bcl-2 proteins share various degrees of homology within four conserved regions termed Bcl-2 homology (BH) 1-4 domains, and are classified into three main subclasses, based on this homology and on their function. The first class comprises the antiapoptotic proteins $\mathrm{Bcl}-2, \mathrm{Bcl}-\mathrm{x}_{\mathrm{L}}, \mathrm{Bcl}-\mathrm{w}, \mathrm{Mcl}-1$, and $\mathrm{A} 1$, containing all four $\mathrm{BH}$ domains; the second class includes the proapoptotic multidomain Bax, Bak, and Bok, containing BH 1-3 domains; and finally, the third class of proapoptotic members of the family includes Bid, Bim, Bad, Bik, Bmf, Hrk, Noxa, and Puma, all possessing only the BH3 domain (named BH3-only proteins). Following different intracellular stress signals, members of the BH3only subclass are activated and contribute to the activation of Bax and/or Bak. Conformational changes in Bax and Bak associated with their activation allow their insertion into the outer mitochondrial membrane and/or oligomerization into large molecular complexes to form proteolipid pores, resulting in MOMP (267). Bax and Bak have redundant functions as one can generally compensate for the absence of the other $(193,229)$; however, the presence of either one is essential for apoptosis, as mice deficient in both Bax and Bak show severe apoptotic defects and perinatal mortality, and cells simultaneously lacking Bax and Bak are resistant to multiple proapoptotic stimuli $(229,373)$. Some BH3only proteins (named "activators"), such as Bid, Bim, and Puma, directly bind and activate Bax and Bak $(186,218)$, whereas the other BH3-only proteins (named "sensitizers" or "derepressors"), such as Bad and Noxa, can only bind the antiapoptotic proteins, but not Bax and Bak, therefore, promoting apoptosis by preventing the binding and sequestration of the activators by the antiapoptotic proteins $(207,381)$ (Fig. 5). Consistently, $\mathrm{Bid}^{-l-} \mathrm{Bim}^{-{ }_{-}} \mathrm{Puma}^{-{ }^{-}}$triple knockout mice show the same developmental defects observed in $\mathrm{Bax}^{-/} \mathrm{Bak}^{-/-}$double knockout mice; moreover, in cells simultaneously deficient in Bid, Bim, and Puma, Bax, and Bak do not oligomerize in response to various death signals despite the presence of other BH3-only molecules (287). Thus, at least one of these three BH-3 only proteins, Bid, Bim, or Puma, is necessary for activation of Bax and Bak, likely in a cell-dependent and stimulus-dependent fashion. Bid also provides a cross-talk between the extrinsic and the intrinsic pathway. Indeed, in type II cells such as the hepatocytes, death receptor-activated caspase 8 cleaves Bid, which, in turn, translocates to the mitochondria and activates Bax or Bak $(221,235)$.

Besides being caused by the pore-forming activity of Bax and Bak, MOMP can also be triggered by a phenomenon called the MPT characterized by the opening of a multi-protein channel in the contact sites of the mitochondrial inner and outer membrane (PT pore, PTP), inner mitochondrial membrane depolarization, matrix swelling and, eventually, breaches in the mitochondrial outer membrane (48). As a consequence of the loss of the mitochondrial outer membrane integrity, several proapoptotic proteins, including cytochrome $c$, SMAC/ DIABLO, apoptosis-inducing factor (AIF), and endonuclease $\mathrm{G}$ are released from the intermembrane space into the cytosol (299). Whereas cytochrome $c$ and SMAC/DIABLO contribute to the apoptotic cascade by promoting the activation of effector caspases (61, 223) (Fig. 5), AIF and endonuclease G translocate to the nucleus and mediate DNA degradation independent of caspase activity $(177,222)$.

To execute both intrinsic and extrinsic apoptosis, liver cells depend heavily on MOMP and its regulation by the Bcl-2 proteins. Insights on the role of single Bcl-2 proteins in liver biology and pathobiology have been gained from studies employing genetically deficient mice. Among the antiapoptotic members, Bcl- $\mathrm{x}_{\mathrm{L}}$ and $\mathrm{Mcl}-1$, but not $\mathrm{Bcl}-2$, are highly expressed in hepatocytes $(65,350)$. Interestingly, conditional deletion of either $B c l-x_{L}$ or $M c l-1$ in the liver produces a similar phenotype characterized by chronic liver damage and 
liver fibrosis, suggesting $\mathrm{Bcl}-\mathrm{x}_{\mathrm{L}}$ and Mcl-1 have nonredundant functions in the hepatocyte. These mice show spontaneous activation of caspase 3 and 7 , widespread hepatocyte apoptosis, elevated serum aminotransferases, and increased hepatocyte sensitivity to apoptotic stimuli $(156,336,361)$. Consistently, mice with liver-specific conditional deletion of both $\mathrm{Bcl}-x_{L}$ and $\mathrm{Mcl}-\mathrm{l}$ display decreased number of hepatocytes and liver volume on day 18.5 of embryogenesis, and die perinatally due to hepatic failure (156). Therefore, Mcl-1 and $\mathrm{Bcl}-\mathrm{x}_{\mathrm{L}}$ cooperate to regulate liver development and adult liver homeostasis. The liver being constantly exposed to a variety of apoptosis-inducing stimuli, it does not surprise that both Bcl- $\mathrm{x}_{\mathrm{L}}$ and Mcl-1 are simultaneously required to prevent unnecessary cell death. Apoptosis caused by Bcl- $\mathrm{x}_{\mathrm{L}}$ deficiency is completely dependent on the BH3-only protein $\mathrm{Bid}$, as $\mathrm{Bid}^{-/-} \mathrm{Bcl}-\mathrm{x}_{\mathrm{L}}{ }^{-/-}$double knockout mice display levels of spontaneous hepatocyte apoptosis and serum aminotransferases comparable to those of wild type mice (155). Moreover, either Bax or Bak are required for Bid-dependent apoptosis in Bcl- $\mathrm{x}_{\mathrm{L}}$ deficient hepatocytes, as single deletion of Bax or Bak in $B c l-x_{L}{ }^{-1-} \mathrm{Bax}^{-/-}$or $B c l-x_{L}{ }^{-/} \mathrm{Bak}^{-/-}$double knockout mice is not sufficient to prevent spontaneous liver injury, whereas simultaneous deletion of Bax and Bak in $\mathrm{Bcl}-x_{L}^{-/-} \mathrm{Bax}^{-/-} \mathrm{Bak}^{-/-}$triple knockout mice is (155). Both $\mathrm{Bid}^{-/-}$ mice and $\mathrm{Bim}^{-/-}$mice do not have any liver phenotype under physiological conditions (184, 394); however, Bid is essential for FasL-induced hepatocyte apoptosis (394) and contributes to TNF-a-mediated hepatocyte apoptosis together with $\operatorname{Bim}(125,184,392)$, while Bim plays a crucial role in TRAIL-induced liver cell apoptosis $(377,378)$.

\section{Lysosomes}

Lysosomes can undergo selective membrane permeabilization and partial release of their content in response to a variety of death stimuli, including lipid mediators, oxidative stress, photodamage, and, in selected cell types, engagement of death receptors $(44,131)$. Among the lysosomal enzymes released into the cytosol, the lysosomal cathepsins, and especially the aspartic protease cathepsin $\mathrm{D}$ and the cysteine protease cathepsin B, play a major role in the execution of the apoptotic cell death $(44,288)$. These proteases can participate in the cell death process either cooperating with caspases or via caspase-independent mechanisms; the latter become particularly relevant in pathologic conditions, such as cancer, in which caspases are frequently inactive $(98,107)$. In addition, immortalization and transformation during tumori-genesis are associated with enhanced lysosome fragility, increase in cathepsin B expression and sensitization to cathepsin B-mediated cell death, making lysosomes an attractive target in cancer therapy $(96,97,190)$. Cathepsins released in the cytosol following lysosomal membrane permeabilization (LMP) contribute to the apoptotic cascade upstream of the mitochondria $(42,43,72,86,125,126,289,291,325,377,378)$. This process has been referred to as the lysosomal pathway of apoptosis (131) (Fig. 6). Several cathepsin substrates have been identified that can link LMP to mitochondrial dysfunction and MOMP. For example, Bid is cleaved and activated by a number of cysteine cathepsins, as well as the aspartic cathepsin D, both in cell-free systems and in several cell lines $(38,72,86,147$, 325). Cysteine cathepsins also cleave the antiapoptotic Bcl-2, Bcl- $\mathrm{x}_{\mathrm{L}}$, and Mcl-1 $(38,72)$, whereas Bax is a substrate for cathepsin D (33). Finally, cathepsin B contributes to caspase 2 activation and subsequent mitochondrial dysfunction in TNF-a/actinomycin $\mathrm{D}$-treated murine hepatocytes (125), although likely not via direct cleavage, as cathepsins are unable to directly cleave caspases in cell-free systems (325).

What triggers lysosomal permeabilization has been the subject of extensive study in the past few years, especially in the liver, where the lysosomal pathway of apoptosis plays a crucial role both in death receptor-mediated cell death $(94,124,126,378)$ and in several experimental models of liver injury $(20,56,100,132)$. In addition to a number of exogenous agents known to induce LMP, including L-Leucyl-1-leucine methyl ester (351), sphingosine (178), hydroxychloroquine (43), and the antibiotics ciprofloxacin and norfloxacin (42), 
several endogenous mediators of LMP have been identified. One of these mediators is the membrane phospholipid sphingomyelin, which can be converted to ceramide by acid sphingomyelinase in the lysosomal lumen, and subsequently to sphingosine by ceramidase. Accumulation of ceramide or sphingosine within the lysosomes is associated with increased lysosomal membrane permeability and TNF-a-mediated cathepsin D activation $(147,148)$. Binding of TNF-a to TNF-R1 also triggers the recruitment of factor associated with neutral sphingomyelinase activation (FAN) to TNF-R1, which results in stimulation of a neutral sphingomyelinase and generation of sphingosine and ceramide (307). Consistently, FAN is required for TNF-a-induced hepatocyte apoptosis (376). But possibly the most intriguing finding in the liver is that LMP is mediated by proteins of the Bcl-2 family. Several lines of evidence now show the involvement Bax, Bim, Mcl-1, and Bid in lysosomal permeabilization in different models of liver injury $(100,376-378)$. While Bid seems to be required for TNF-a-induced LMP in normal hepatocytes, its presence is dispensable to induce TRAIL-mediated LMP in CCA and hepatocellular carcinoma cells (376-378). TRAIL treatment in these cells results in JNK-mediated activation of Bim, translocation of Bim and Bax to the lysosomes, and Bim/Bax-dependent LMP upstream of mitochondrial dysfunction $(377,378)$. Translocation of Bim and Bax to the lysosomes is mediated by phosphofurin acidic cluster sorting protein-2 (PACS-2) (377), a multifunctional protein regulating membrane traffic, which has also been implicated in translocation of Bid to the mitochondria during TRAIL-induced hepatocyte apoptosis (11). This multiprotein complex comprising Bim, Bax, and PACS-2 has been named the PIXosome (Fig. 7).

\section{Endoplasmic reticulum}

Hepatocytes are abundant in both smooth ER (SER) and rough ER (RER). Several of the metabolic functions of the hepatocyte are localized to either the SER, such as xenobiotic metabolism, or the RER, such as protein folding. Gluconeogenesis, lipid synthesis, and storage and regulation of intracellular calcium levels are some of the other functions localized in the ER. The ER is susceptible to alterations in its myriad functions, leading to a state of ER stress. Classically, the protein folding function of the ER is interrupted under conditions of ER stress. A homeostatic adaptive pathway is activated under conditions of ER stress, termed the unfolded protein response (UPR), as it was first described under conditions of accumulation of misfolded proteins in the ER lumen (200). The UPR is now recognized as a series of ER-to-nucleus signals that collectively are geared toward restoring ER homeostasis (Fig. 8). Besides misfolded proteins, several other stimuli, not all of which disrupt protein folding, can activate the UPR sensors (212). ER stress can be induced by calcium depletion, such as with thapsigargin, glycosylation inhibitors, such as tunicamycin, alterations in redox protein folding, and lipid loading of the ER, such as with palmitate.

The three canonical UPR sensors are inositol requiring protein 1a (IRE1a), protein kinase RNA-like ER kinase (PERK), and activating transcription factor 6a (ATF6a) (240). All three are ER transmembrane proteins, normally inhibited by lumenal binding to the ER chaperone GRP78/BiP (glucose regulated protein 78/immunoglobulin binding protein). The UPR sensors are activated upon release of inhibitory binding by BiP, though there is evidence for direct activation of IRE1a by misfolded peptides in yeast $(28,113)$. Upon activation, PERK phosphorylates the a subunit of eukaryotic initiation factor 2 (eIF2a) leading to global attenuation of mRNA translation; however, the transcription factor activating transcription factor 4 (ATF4) is preferentially translated. ATF4 increases transcription of several genes involved in redox response, amino acid metabolism and the transcription factor $\mathrm{C} / \mathrm{EBP}$ homologous protein (CHOP). IRE1a has dual kinase and ribonuclease (RNase) functions. IRE1a splices XBP-1 to generate the mRNA for spliced XBP-1, a potent transcription factor that activates transcription of genes encoding ER chaperones, endoplasmic reticulum-associated degradation (ERAD) components, and ER 
biogenesis (150). Regulated IRE1a-dependent decay of mRNA has been observed in vitro, and may modulate liver injury in vivo(165). ATF6a is cleaved in the Golgi by site 1 protease (S1P) and site 2 protease (S2P) to an active transcription factor, which drives expression of several UPR target genes, including XBP-1.

The UPR sensors buffer physiologic and pathologic variations in protein folding and ER stress and are overwhelmingly an adaptive response, yet under conditions of sustained or relentless ER stress, apoptosis will occur $(240,331)$. Several mediators of ER stress-induced apoptosis have been defined, CHOP being one of them, as its absence protects against ER stress-induced apoptosis (406). Growth arrest and DNA damage inducible protein (Gadd34) is a CHOP target gene. Along with protein phosphatase 1 (PP1), it leads to dephosphorylation of eIF2a, leading to resumption of protein translation. The entry of nascent proteins into the ER increases the folding load and thus worsens ER stress (241). Proapoptotic transcriptional targets of CHOP are DR5 and Bim $(282,389)$. Moreover, exogenous $\mathrm{CHOP}$ can promote apoptosis by decreasing the antiapoptotic protein $\mathrm{Bcl}-2$ (247). Recent work has linked the CHOP target ER oxidase 1a (ERO1a)-induced oxidative stress, the calcium sensing kinase CaMKII, and the ER calcium channel inositol 1,2,5triphosphate receptor activity to ER stress-induced apoptosis (220, 345). IRE1a can also activate apoptotic signaling pathways by recruitment of signaling proteins. TRAF2 is recruited by activated IRE1a, activating the stress kinase JNK, which can engage the intrinsic apoptotic machinery at many levels $(352,386)$.

Recent studies have linked UPR sensors to many aspects of the physiologic functions of the liver, such as lipogenesis and gluconeogenesis; these are generally independent of ER stress $(214,370)$. However, ER stress has been observed in many liver diseases. UPR pathways are activated in the livers of obese patients (120). Furthermore, palmitic acid, a physiologic free fatty acid which can be toxic when elevated, activates UPR pathways in cell culture systems (368). CHOP can transcriptionally activate the proapoptotic protein PUMA and induce expression of DR5 in palmitic acid-treated hepatocytes $(58,59)$. Hepatitis $\mathrm{C}$ virus infection has also been shown to activate the UPR (250). This may be an attempt at subverting the cellular machinery to synthesize and correctly fold new viral proteins, and may not be directly apoptogenic. However, low-level activation of the UPR promotes responsiveness and adaptation to additional misfolded proteins. UPR is also activated by cholestasis (40). In alcohol-induced liver injury, hepatocyte apoptosis is CHOP dependent (172). In acute toxin-induced liver injury, such as tunicamycin, microvesicular steatosis develops due to activation of the UPR and increases in de novo lipogenesis (214). IRE1a activation may be protective, as demonstrated in a mouse model of APAP-induced liver injury, through IRE1a-dependent degradation of cytochrome P450 family mRNAs, leading to decrease in oxidative metabolism of APAP (165). Thus, the UPR is activated in the liver under many different conditions, and may be part of the general stress response of the liver. In some instances, it appears to be protective, while in others it may mediate apoptosis and injury.

\section{Necrosis: Definitions, concepts, and relevance in the liver}

Necrosis is a term derived from the Greek "necros" for corpse (162). In cell culture and presumably in vivo, cells undergoing necrosis form large plasma membrane blebs devoid of organelles (115). Loss of the plasma membrane permeability barrier due to bleb rupture is a cardinal morphologic feature of necrosis (115); indeed, experimentally, necrosis is identified by uptake of membrane impermeant dyes (e.g., trypan blue, sytox green, propidium iodide, etc.). Rupture of the plasma membrane results in release of cellular constituents into the extracellular environment, a pathological process which can elicit a significant inflammatory response (162). Thus, necrosis is thought to be a much more inflammatory mode of cell 
death as compared to apoptosis. Necrosis has also been considered an unregulated form of cell death, with multiple simultaneous cellular events culminating in cell swelling and plasma membrane rupture. These necrotic processes include loss of ion homeostasis causing cell swelling, increases in cellular free calcium, activation of diverse proteases and phospholipases, and loss of mitochondrial integrity (238). A great deal of attention has been focused on the role of mitochondria in necrosis as ATP depletion due to loss of mitochondrial oxidative phosphorylation is a biochemical hallmark of necrosis. Mitochondrial dysfunction in necrosis is characterized by the MPT (202). The MPT results in a collapse of ion gradients across the inner mitochondrial membrane causing a drop in the mitochondrial membrane potential, an essential component of the proton motive force which drives oxidative phosphorylation. Loss of oxidative phosphorylation is associated with rapid depletion of cellular ATP, precluding maintenance of ion pumps, intracellular calcium homeostasis, and other cellular processes (238). The molecular characterization of the MPT remains controversial. Although the voltage-dependent anion channel, and the adenine nucleotide transporter have been implicated in the MPT, knockout of either gene does not prevent the MPT $(285,366)$. However, knockout of cyclophilin D, a component of the pore that regulates mitochondrial depolarization, does inhibit the MPT and limit ischemic tissue injury (285).

Necrosis is a feature of APAP-induced liver injury. Irreversible mitochondrial dysfunction is a prerequisite for necrotic cell death, therefore, several studies have characterized the mitochondrial changes that occur in hepatocytes both in vivo and in vitro upon APAP challenge (192). Mice deficient in cyclophilin D are protected from APAP-induced liver injury and DNA damage (284). In APAP overdose, the toxic metabolite NAPQI is generated by cytochrome $\mathrm{p} 450$-mediated metabolism. NAPQI detoxification requires glutathione, thus glutathione depletion occurs early in APAP overdose (16). This is associated with oxidative stress and nitrative stress. The kinetic of ALT release is dependent on nitration of the protein manganese superoxide dismutase by nitric oxide generated by neuronal nitric oxide synthase (nNOS) (4). The overall relevance of this is questionable, as nNOS-deficient mice had similar glutathione depletion and histologic injury. The stress kinase JNK is activated by APAP and mediates liver injury, as inhibition of JNK in APAP-injected mice protects from APAP toxicity (135). This protection occurs in spite of comparable glutathione depletion and covalent protein binding by NAPQI in mice treated with JNK inhibitor compared with control mice. Release of DAMPs occurs in APAP toxicity, and acts as a stimulus for activation of inflammatory pathways, as discussed in detail in Section "Portal Blood Flow and Toxic Xenobiotics." This could occur from primary oncotic necrosis or be due to secondary necrosis of apoptotic hepatocytes. Thus, a model emerges where APAP has multiple cellular targets and activates multiple pathways that can result in both apoptotic and necrotic cell death.

Necrotic cell death is also a prominent feature of ischemia/reperfusion (I/R) liver injury. I/R is a complex process that results in hepatic cell death via a combination of oncotic necrosis and apoptosis $(1,169)$. The cellular damage initiates during the ischemic phase, when interruption of the blood (and oxygen) supply causes a drop in ATP production by oxidative phosphorylation, and continues during the reperfusion phase. A second round of injury then ensues from the activation of the innate immune system, in particular with the activation of Kupffer cells and infiltration and accumulation of neutrophils and T lymphocytes (1). Warm ischemia occurs at body temperature, when the blood flow to the liver is temporarily interrupted, such as during surgical resection; cold ischemia occurs during cold perfusion and storage of the liver for transplantation after explantation from the donor. Cell death during I/R injury targets mainly hepatocytes and LSEC. Hepatocytes seem to be most susceptible to necrotic cell death after warm ischemia, whereas LSEC are preferentially targeted after cold ischemia $(46,52)$. During the ischemic phase, necrosis is delayed by the 
acidosis associated with hypoxia (117). The damage occurs mainly during warm reperfusion, when the physiological cellular $\mathrm{pH}$ and oxygen supply is restored, resulting in opening of MPT pores, mitochondrial inner membrane permeabilization, drop in mitochondrial membrane potential, formation of ROS, perturbations in the homeostatic concentrations of $\mathrm{Ca}^{2+}, \mathrm{Na}^{+}$, and $\mathrm{H}^{+}$, and cell swelling, leading to necrotic cell death. Necrosis is then further exacerbated by the effect of ROS and proinflammatory cytokines, including TNF- $\alpha$ and IL-1 $\beta$, produced by activated Kupffer cells, which recruit and activate neutrophils and CD4+ T lymphocytes, activate LSEC and stimulate their adhesion to platelets, and stimulate further ROS and inflammatory cytokine and chemokine production in hepatocytes $(32,144,233,262,340)$. Therapeutic strategies aimed to prevent ATP depletion, MPT, Kupffer cells activation, neutrophils infiltration, and/or ROS damage have all been proven useful to reduce I/R liver injury $(51,161,170,188,198,257,274,340)$. However, apoptosis can also occur as a result of MPT; indeed, inhibitors of MPT, such as cyclosporin A and its analogs, administered during reperfusion prevent both I/R-induced apoptosis and necrosis $(187,188,189)$. MPT triggers apoptosis via the cytochrome cmediated activation of caspase 9 through the formation of the apoptosome. This process is completely ATP dependent, therefore, it has been suggested that the number of mitochondria affected by the MPT determines the cellular response to the damage. When the number of damaged mitochondria in the hepatocyte is relatively low, the cellular ATP level is preserved and MOMP would result in apoptosis rather than necrosis. On the contrary, when the majority of mitochondria in the cell are dysfunctional, the normal ATP production can no longer be maintained causing the cell to die by necrosis $(169,188,216)$. Therefore, apoptosis could represent an early phase of the I/R injury or the response to a milder injury. Several studies underlined the importance of apoptosis in hepatic cold ischemia/warm reperfusion in both animal models and human allografts $(41,196,205,266,321)$. Similarly to necrosis, apoptosis targets primarily hepatocytes and LSEC, with LSEC apoptosis generally preceding hepatocyte apoptosis $(196,321)$. Pharmacological and genetic manipulation of critical apoptotic mediators (such as caspases and Bcl-2 proteins) have shown to reduce hepatic I/R injury $(21,35,76,264,312,313)$.

\section{RIPK1-mediated cell death by necrosis or necroptosis}

Recently, there has been renewed interest in necrosis as the receptor interacting kinase-1 (RIPK1 or RIP-1) has been implicated in regulated necrotic pathways and is druggable by kinase inhibition (81). Pathways have recently been described that mediate a form of programmed and regulated necrosis, often referred to as necroptosis (357). This specialized pathway of necrosis has been best described in L929 mouse fibrosarcoma cells (357). However, developmental observations in mice and in other models have served to substantiate this mode of cell death. The best trigger described to date for necroptosis has been TNF-a (Fig. 9) (108). Following TNF-a binding to its cognate death receptor TNF-R1, cIAP1 and 2 are recruited to the receptor complex promoting ubiquitination of RIPK1 and other proteins (80). These cIAP-driven ubiquitination events favor NF- $\kappa \mathrm{B}$ activation, which promotes inflammatory signaling, but also ensures survival of the cell by enhancing NF- $\kappa B$ mediated transcriptional upregulation of $\mathrm{cFLIP}_{\mathrm{L}}$ which effectively inhibits TNF-a induced, caspase 8-mediated apoptosis (70). Inflammatory signaling by TNF-a is the default response to this ligand. In the liver, if NF- $\kappa \mathrm{B}$ is inhibited, cell death by a caspase 8 -dependent apoptotic pathway occurs dependent upon the proapoptotic BH3-only proteins, Bid or Bim (184). However, if RIPK1 is not ubiquitinated, or if it is deubiquitinated by CYLD (270), it can initiate a cell death cascade by phosphorylating and activating RIPK3, which, in turn, phosphorylates and activates the mitochondrial phosphatase phosphoglycerate mutase 5 (PGAM5) $(62,328)$. Interestingly, active PGAM5 appears to mediate multiple necrotic cell death pathways; how this occurs and its relevance to multiple human disease models will be a subject of intense investigation. However, if indeed PGAM5 is critical for necrosis, its 
function may provide insight into the MPT in general, and may prove to be a critical target for preventing multiple forms of liver injury. The pharmacologic small molecule necrostatin 1 inhibits RIPK1 and prevents necroptosis in most cellular models-a very useful experimental tool (81). Necroptotic signaling is also suppressed by caspase 8-mediated cleavage of RIPK1 and/or CYLD (270). In this regard, caspase 8 activity is a major inhibitor of necroptotic cell signaling, and therefore, apoptosis appears to be the cell's preferred route of demise. For example, Casp $8^{-/-}$knockout mice are embryonic lethal due to embryonic necroptosis, a phenotype rescued by simultaneous knockout of RIPK3 (Casp $8^{-/-}$Ripk ${ }^{-/-}$ double knockout mice) $(180,272,273,283)$. Also in selected experimental models, genetic or pharmacologic inhibition of caspase 8 promotes cell death by necroptosis (357). If we are to prevent liver injury in man, a full understanding of these complex pathways is essential.

Given a major role for TNF- $a$ signaling in liver pathology, a logical question is does TNF- $\mathrm{a}$ cause necroptosis in hepatocytes. Unexpectedly, the answer may well be no. First, necroptosis requires RIPK3, and RIPK3 is minimally expressed in hepatocytes (329). Second, conditional deletion of caspase 8 in hepatocytes ameliorates TNF-a-mediated liver injury when NF- $\kappa B$ signaling is impaired (226); if necroptosis was present, caspase 8 deletion would accentuate the injury. Finally, numerous studies have reported that in experimental models of liver diseases and in humans with hepatitis $\mathrm{C}$, pharmacologic caspase inhibitors are salutary rather than toxic, which would be predicted if necroptosis was occurring due to caspase 8 inhibition $(21,53,159,160,230,245,265,280,383,400)$. Thus, there is no evidence that necroptosis occurs in the liver, unlike in the ileum, where conditional caspase 8 deletion does cause ileitis (136).

RIPK1 can also be activated by processes independent of death receptors. For example, degradation of cIAPs can promote formation of a RIPoptosome $(29,102,343)$, a high molecular weight complex containing RIPK1, FADD and caspase 8. This complex can cause either caspase 8-dependent apoptosis or caspase 8-independent necroptosis. Formation of this complex is inhibited by necrostatin, indicating the kinase activity of RIPK1 is required for its assembly and for RIPoptosome-mediated cell death. Potentially, cIAP depletion in hepatocytes by toxins or even signal transduction cascades (e.g., those initiated by the death ligand TNF-like weak inducer of apoptosis or TWEAK) may lead to RIPoptosome formation and cell death by this complex (166). The potential role of RIPK1 and the RIPoptosome in liver injury certainly merits further examination; and it is likely that examples of RIPK1 mediated cell death will be identified in liver injury in the future.

\section{Modes of cell death and liver tissue injury: Misperceptions and challenges}

The ultimate goal of understanding mechanisms of cell death is to prevent tissue injury in pathophysiologic processes. A common question is, therefore, which mode of cell death, apoptosis, necrosis, or a mixed form of cell death, is occurring in a disease process. However, this is often difficult, and the current methodology renders analysis regarding the mode of cell death in pathophysiology challenging. Indeed, it is extremely difficult in vivo to ascertain which mode of cell death is occurring for the reasons we will review in the following paragraphs.

There are many misperceptions regarding apoptosis in liver tissue injury. In a physiologic setting, apoptosis is defined by the formation of membrane-limited apoptotic bodies occurring by a poorly understood process of cellular fragmentation. The apoptotic bodies release "find me" signals which attract phagocytic cells; one notes already that the presence of phagocytic cells, which are predominantly macrophages, is considered by many to be a hallmark of inflammation. The mediators of the "find me" signals, termed the "scent of death," include ATP, UTP, adenosine, fractalkine, and lysophosphatidly choline (91, 121, $248,258)$. The recruited phagocytic cells then engulf the apoptotic bodies resulting in a 
supposed "clean elimination" of the cellular debris (342); the engulfment of apoptotic cells is termed efferocytosis (354). However, efferocytosis by Kupffer cells, the resident macrophages in the liver, is not innocuous. Indeed, Kupffer cell efferocytosis can result in their activation and elicit expression of death ligands, thereby further promoting liver injury in a feed forward process (54). It has been argued that the role of caspases in apoptosis is to "chew up" the cellular constituents into non inflammatory molecules (243). However, quantitative profiling of caspase-cleaved substrates reveals different drug-induced and celltype patters in apoptosis (316). Hence, even caspase cleavage of substrates during apoptosis is not a uniform process, and depends upon the stimulus and the cell type. In this regard, it would appear that the biochemical processes occurring during liver cell apoptosis in many distinct pathophysiologic conditions may differ, and certainly apoptosis cannot be considered as a uniform process.

It is widely assumed that since apoptosis results in cell membrane-defined bodies, cytosolic transaminases AST and ALT cannot be released into the serum by this mode of the cell death. This is a misperception which is simply incorrect. Schulte-Hermann and colleagues were the first to recognize the correlation between apoptosis and serum transaminase elevation by demonstrating that 5 hours after a single intravenous injection of transforming growth factor beta in the rat both hepatocyte apoptosis and increases in serum AST and ALT occur (AST and ALT were approximately $300 \mathrm{U} / \mathrm{L}$ ) (271). This observation is, however, not unique to this ligand-mediated apoptosis, as hepatocyte-specific deletion of either one the mitochondria-localized Bcl-2 antiapoptotic proteins, Bcl- $\mathrm{X}_{\mathrm{L}}$ or Mcl-1, results in elevated serum AST and ALT values $(336,371)$. Cell death by the mere hepatocyte-specific deletion of Bcl- $\mathrm{X}_{\mathrm{L}}$ or Mcl-1 occurs via apoptosis, as concomitant deletion of the proapoptotic Bak, prevents hepatocyte apoptosis and the rise in serum ALT values (154). Also, exogenous administration of Fas agonistic antibodies results in massive elevations of serum transaminases which are prevented in Bcl-2 transgenic animals (210). Other cellular constituents are also released into the serum during liver cell apoptosis. Hepatocyte cytokeratin 18 is cleaved by caspase 3 to yield a neoepitope which is recognized by specific antisera employed in ELISA assays (99). Circulating cytokerain 18 fragments have been recognized in a wide variety of liver diseases, such as hepatitis $\mathrm{C}$ and nonalcoholic steatohepatitis $(99,339)$. Thus, these data collectively demonstrate that serum transaminases and other cellular constituents are elevated by induction of hepatocyte apoptosis. Perhaps the release of microparticles, such as exosome-like structures, explains this phenomenon as initially proposed by Schulte-Hermann in 1993.

The second misperception is that hepatocyte apoptosis is not proinflammatory in the liver. Several studies have shown that either acute or chronic apoptosis is indeed associated with inflammation. The best example of this is, again, the hepatocyte-specific deletion of $\mathrm{Bcl}-\mathrm{X}_{\mathrm{L}}$ or Mcl-1 in the mouse. As described above, these animals have ongoing hepatocyte apoptosis. Interestingly, the livers of these animals develop chronic inflammation with elevation of macrophage markers, such as MCP-1 and CD68 (154). The chronic inflammation is also associated with fibrosis and hepatocarcinogenesis, recapitulating the liver injury/inflammation/fibrosis/cancer sequence observed in human liver diseases (154). Acute hepatocyte apoptosis is also associated with elevation of inflammatory markers. Fas agonists induce hepatic chemokine expression and promote inflammation in the liver (92). It should also be noted that in their review, Martin and colleagues recognize that death receptor-mediated apoptosis challenges the model of apoptosis as a noninflammatory condition (243). We note that death receptor mediated apoptosis has been implicated in many liver diseases (396), and hence, may explain the link between apoptosis and inflammation in the liver. 
If apoptotic bodies are not rapidly engulfed [defective efferocytosis (354)], their membranes break down, resulting in secondary necrosis (319). Therefore, when hepatocytes apoptosis is rapid and extensive, it is likely that not all the apoptotic bodies are engulfed by phagocytic cells in a timely and efficient manner. In these situations, secondary necrosis would be common. Unlike most other epithelia in which the apoptotic cells can be rapidly shed into a lumen, hepatocytes have no lumen to be shed into, and hence, the liver may be uniquely susceptible to secondary necrosis during apoptotic injury. Also the possibility that lipid laden Kupffer cells, such as found in steatosis syndromes, may be defective in efferocytosis, thereby aggravating liver injury, merits close examination (354). These and the above concepts suggest that hepatocyte apoptosis can be a proinflammatory and profibrogenic stimulus, leading to the release of cellular constituents into the serum and liver injury (55).

Necrosis clearly occurs in liver injury, but separating necrosis from apoptosis in vivo is difficult. Moreover, when functional and morphologic endpoint analyses are used in vivo, it is impossible to differentiate necrosis, necroptosis, and secondary necrosis. Real-time kinetic analyses in isolated cells are needed to delineate the signaling phases of these phenomena $(204,356)$. Indeed, in apoptotic signaling, key players have been identified by complementary in vitro and in vivo experiments using chemical and genetic inhibitors. On the other hand, there are no positive makers for necrosis, as there are for apoptosis (e.g., caspase activation), and the absence of recognized apoptotic markers often becomes the feature by which necrosis is defined. In the absence of positive markers, loss-of-function paradigms become important to establish the mode of cell death. Unfortunately, given the plethora of cellular events culminating in necrosis, a single loss-of-function paradigm will not be universal for all causes of necrosis. Although RIPK3 is essential for many forms of necrosis, it does not seem to be expressed in liver, making loss of function paradigms involving RIPK3 difficult in this organ (see Section "RIPK1-mediated cell death by necrosis or necroptosis"). The MPT is a major cause of necrosis (290). MPT results in a collapse of the mitochondrial membrane potential, failure of oxidative phosphorylation with loss of cellular ATP, and generation of ROS by the mitochondria (290). The mitochondrial membrane potential is, in part, dependent upon cyclophilin D. Genetic deletion of cyclophilin D reveals a critical role for the mitochondrial membrane potential in necrosis, but not apoptosis $(15,260)$. Mice genetically deficient in cyclophilin D are resistance to IRI of the heart, and primary hepatocytes isolated from these animals are largely protected from necrotic cell death by calcium overload and oxidative stress (15). Cyclophilin D deletion would appear to be one approach to inhibit necrosis and determine the role of this mode of cell death in liver tissue injury.

There are also other modes of cell death including autophagy, entosis, mitotic catastrophe, netosis, parthanatos, and pyroptosis which can be defined biochemically and by specific inhibitory interventions (109). Pyroptosis is an especially interesting form of cell death mediated by caspase-1 (286). This form of cell death, which occurs in inflammatory conditions associated with microbial infections, may also occur in liver disease, but yet has to be examined carefully. The role of pyroptosis and other forms of cell death in liver injury remains unexplored and merits examination. Thus, tissue injury in liver pathobiology remains complex, likely invokes many forms of cell death, will usually be mixed with one mode or another predominating, and will require loss-of-function paradigms to indicate a specific process. Absence of proof is simply not proof of absence.

\section{Unique Regulatory Platform and Pathways} Inflammasome

Inflammasomes are intracellular signaling platforms that activate caspase 1, which then cleaves prointerleukin- $1 \beta$ into active IL-1 $\beta$ (122). IL-1 $\beta$-dependent proinflammatory 
signaling is activated both in infection and in sterile inflammation. Inflammasomeassociated inflammation also promotes formation of ROS, which may induce tissue and cellular injury. In certain microbial infections, caspase 1 within the macrophage can induce pyroptosis (251). Like necrosis, this form of cell death also results in cell lysis eliciting further inflammation. Also, the associated loss of macrophages further impairs tissue clearance of apoptotic cells, increasing the occurrence of secondary necrosis. Whether this form of cell death can also occur in the absence of microbial infections remains uncertain. Inflammasomes are formed upon activation of an intracellular PRR; several have been identified, of which NLRP3 is best characterized (Fig. 3). Other adaptor proteins recruited to the platform include ASC (apoptosis-associated speck-like protein containing a CARD) and pro-caspase 1. Active caspase 1 cleaves the inactive precursors of the proinflammatory cytokines, pro-IL-1 $\beta$ and pro-IL-18, to their active forms, IL-1 $\beta$ and IL-18, respectively. The NLRP3 inflammasome can be activated by diverse inflammatory stimuli, that vary in structure and function, such as uric acid, ATP, HMGB-1, asbestos, silica, hyaluronan, and even downstream of ER stress $(249,259)$. The active forms of IL- $1 \beta$ and IL-18 are secreted and via their cell surface receptors on target cells activate many proinflammatory genes. Pro IL-1 $\beta$ is not constitutively expressed by innate immune cells; hence before its secretion, it must be induced transcriptionally, translated into the precursor protein, and then cleaved by an active inflammasome. This induction of pro IL-1 $\beta$ is referred to as priming.

Inflammasome activation as part of the innate immune response to endogenous DAMPs or perhaps gut-derived PAMPs is implicated in acute and chronic sterile inflammatory disorders of the liver. Using mouse models that lack functional inflammasome components, via either chemical or genetic inhibition, this signaling pathway has been implicated in APAP-induced acute liver injury, IRI, alcoholic steatohepatitis, and NAFLD (67, 242, 355, 405).

In APAP-induced liver injury in mice, release of apoptotic DNA from damaged and dead hepatocytes can activate TLR9-dependent transcription of pro-IL-1 $\beta$. Indeed, mice lacking caspase 1, ASC or Nalp3 are protected from liver injury and APAP-induced death (167). In another study, it was demonstrated that the inflammasome and other inflammatory pathways are activated early $(1 \mathrm{~h})$ after APAP injection in Kupffer cells. Liver perfusate from APAPinjected mice further activated a macrophage cell line in culture, presumably due to DAMPs released from dead hepatocytes (242). However, Williams et al. did not recapitulate some of these findings as discussed above (379). In mouse and rat models of warm IRI inflammasome activation occurs. Blocking IL-1 receptor or decreasing Nalp3 expression via RNA interference protects from IRI $(317,405)$. Both TLR4 and TLR9 are activated in bone marrow-derived cells by DAMPs, and in chimeric mice generated by bone marrow transplantation, the absence of either TLR4 or TLR9 protected from liver injury $(17,349)$. Serum IL-1 levels are elevated in patients with alcoholic hepatitis, in livers of alcohol-fed mice and in ethanol-treated cultured hepatocytes $(246,353)$. Inflammasome activation has also been studied in the context of metabolic syndrome and obesity-related disorders (23). Palmitate, a potentially toxic free fatty acid, can activate the NLRP3 inflammasome, leading to secretion of IL-1 $\beta$ (374). Mice lacking Nlrp3 are protected from obesity-induced fatty liver (355). In another model of steatohepatitis using the methionine- and choline-deficient diet, mice lacking caspase-1 have decreased liver inflammation and fibrosis (84). However, the complexity of this field is underscored by this study that demonstrates an indirect relationship between inflammasome components and fatty liver (149). In this study, mouse lacking caspase 1 or ASC were more susceptible to liver injury and inflammation induced by the methionine- and choline-deficient diet. This susceptibility could be transmitted to cohoused wild-type mice. The authors demonstrate that changes in gut microbiota, and microbiota-activated inflammatory signaling in the liver underlies this susceptibility. Thus, emerging data implicate the inflamma-some in liver inflammation. Additional studies are 
needed to further define the individual contribution of DAMPs, PAMPs, and inflammasome components to liver inflammation.

\section{MicroRNA}

While many apoptosis-related proteins are regulated by post-translational modifications, several are also controlled at the level of protein expression. An emerging RNA-based layer of regulation has been described whereby microRNAs repress the protein levels of genes that contain partial and sometimes imperfect microRNA:mRNA complementarity. MicroRNAs are processed first by endonucleolytic cleavage of the primary transcript by a nuclear protein complex containing the RNase Drosha. The resulting partially processed RNA, the pre-mir, is then cleaved a second time by the cytoplasmic RNase Dicer (215). The microRNA genes are expressed in a tissue-specific manner, and a classic example of this specificity is the observation that miR-122 is highly expressed in hepatocytes, but is largely absent from other cell types within the liver or other organs (63). Hepatocytes express miR-122 at such a high level that it is estimated to comprise a remarkable seventy two percent of the total hepatocyte microRNAs (211).

A model for microRNA function is emerging whereby microRNAs help to fine-tune cellular functions by altering the level of hundreds of target proteins rather than determining the cellular phenotype per se $(14,311)$. Two recent investigations have utilized Cre-lox technology to elucidate the contribution of microRNAs to liver homeostasis $(143,309)$. Both groups employed mice with the Dicer 1 gene flanked by lox sites crossed with mice expressing Cre recombinase, either under control of the albumin promoter plus an alphafetoprotein enhancer (AlfpCre), or under control of the albumin promoter alone (AlbCre). As expected, hepatocyte microRNAs were decreased in Dicer $1^{\text {flox/flox;AlfpCre mice, as seen }}$ by a nearly 50 -fold decrease in hepatocyte miR-122 levels, while microRNAs derived from supporting cells in the liver (e.g., granulocyte-derived miR-223) were unchanged (143).

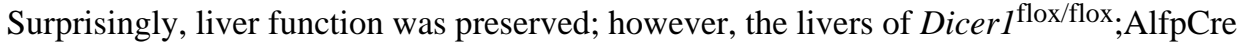
mice were not normal. The distinction here is that liver functions, namely, synthesis, metabolism, and secretion were not disrupted, as defined by blood glucose, albumin, bilirubin, and cholesterol levels measured in 3-month-old mice. As mentioned above, liver function can be separated from liver injury. However, Dicer I $^{\text {flox/flox; }}$ AlfpCre mice displayed evidence of liver injury, showing mildly altered hepatocyte appearance at 72 days of age, and, significant portal inflammation by 101 days. Mice also had elevated serum transaminases, with greater than 3.6-fold elevated ALT. Ductular proliferation and increased apoptotic cells were apparent over time, both indicators of injury (143).

A separate line of mice were generated with tissue-specific genetic deletion of Dicerl using an albumin-driven Cre (Dicer I flox/flox;AlbCre), resulting in expression only in hepatocytes beginning after birth (309). Livers from Dicer I flox/flox;AlbCre mice had elevated apoptosis and proliferation. Because of the significant cell death in hepatocytes, and the rare persistence of hepatocytes that had escaped Cre-mediated Dicerl deletion, by 12 weeks of age, the liver had been nearly completely repopulated by Dicer1-expressing cells, consistent with other mouse models where significant hepatocyte cell death occurs (300). During repopulation, apoptosis was almost exclusive to the Dicerl-negative cells, suggesting that loss of microRNAs promotes apoptotic signaling. Despite near-total replacement of the liver by Dicer 1-positive hepatocytes, by 6-12 months-of-age Dicer $1^{\text {flox/flox;AlbCre mice developed }}$ hepatocellular carcinoma. Tumors exhibited low Dicer and decreased miR-122 expression, indicating that Dicerl-deficient hepatocytes are the likely source of tumorigenesis. Tumor cells exhibited activation of Akt, and a subset demonstrated elevated Mycn and Bcl2 mRNA levels, consistent with apoptosis resistance in malignant cells (309). 
The role of miR-122 in the liver is broad, including regulation of cholesterol biogenesis (203), proliferation (388), viral propagation (175), and apoptosis (228). miR-122 is encoded by the $h c r$ noncoding RNA transcript (63) and is expressed from chromosome 18 in human hepatocytes. The mechanisms controlling microRNA stability and degradation, including miR-122, are not fully understood. It is well known that messenger RNAs are stabilized by the addition of a poly(A) tail, and recent evidence suggest monoadenylation of microRNAs at the $3^{\prime}$ end may enhance stability. For example, miR-122 has been demonstrated to be stabilized by monoadenylation of the $3^{\prime}$ end catalyzed by the noncanonical poly-A polymerase Gld-2 (183). The stabilized miR-122 then can target cytoplasmic polyadenylation element binding protein (CPEB), a protein that promotes poly $(\mathrm{A})$ synthesis by nucleating a polyadenylation complex. A decrease in CPEB results in decreased polyadenylation of another transcript, $p 53$ (Fig. 10). Thus regulated adenylation (mono- for miR-122 and poly-for $p 53$ ) alters senescence as follows: silencing of Gld-2 protein decreased miR-122 levels due to lack of monoadenylation. Decreased miR-122 levels released inhibition of CPEB, and CPEB reporter levels increased. Elevated CPEB then cooperated to increase polyadenylation of $p 53$ resulting in a stabilized mRNA, promoting cellular senescence (49). This complicated but elegant pathway was delineated in human skin fibroblasts, which express low levels of miR-122. It remains to be seen whether this miR-122:CPEB:p53 regulatory circuit is functional in hepatocytes and if it influences $p 53$ dependent apoptosis in liver disease, but $p 53 \mathrm{mRNA}$ levels were observed to be elevated in livers of mice with Dicer deletion (143).

Because of the growing number studies that have demonstrated individual microRNA:target interactions for proteins involved in apoptosis signaling pathways, we cannot hope to present a complete catalog of these interactions. Instead, here we will highlight several examples to illustrate the broader concept that microRNAs affect liver cell death, especially as it relates to liver pathophysiology.

Among the microRNAs that were found to be repressed in a model of Myc-dependent cancer were members of the miR-26, miR-29, and let-7 microRNA families (64), suggesting these microRNAs may play a role in cancer initiation or progression. Mice with liverspecific induction of Myc develop liver tumors that express decreased levels of miR-26a, among other altered microRNAs. Similarly, human tumor samples were also found to have decreased miR-26a levels. Once tumors had developed, mice treated with virally delivered miR-26a had small or absent tumors compared to control (green fluorescent protein-GFP) transduced mice, where $75 \%$ had near complete replacement of the liver by tumor. TUNEL staining of liver tissue demonstrated increased tumor cell death in miR-26a treated mice while adjacent nontumor liver did not have increased apoptosis, suggesting therapeutic specificity (199). The mechanism by which miR-26a transduction induced tumor cell death was not reported, though the authors did rule out c-Myc itself as a miR-26a target (199).

We and others demonstrated direct targeting of an anti-apoptotic protein, Mcl-1, by a microRNA that is decreased in tumor cells, miR-29. The miR-29 family consists of 3 isoforms, miR-29a, 29b, and 29c, and miR-29 family member expression is decreased in multiple cancer types (362), including hepatocellular carcinoma (387), and CCA (255). Through direct binding to the Mcl-1 3'UTR [and in hepatocellular cancer (HCC) cells to the Bcl-2 3'UTR as well], miR-29 acts to decrease protein levels of Mcl-1. In tumor cells that lack robust miR-29 expression, Mcl-1 is released from repression and expressed at high levels. However, replacing miR-29 by transfection resulted in decreased Mcl-1 protein, and sensitized cells to apoptosis induced by TRAIL (255), serum deprivations plus hypoxia, doxorubicin, curcumin, and etoposide (387). In addition, HCC cells transfected with miR-29b were delayed in forming tumors and formed smaller tumors when implanted in a xenograft model. 
Hepatitis B virus (HBV) infection is a major health threat, with an estimated 1 billion people infected worldwide. Recently, the viral protein $\mathrm{HBx}$ was demonstrated to decrease cellular let-7 levels, and HBx protein was inversely correlated to let-7 in human HCC samples. The authors then demonstrated that let-7 targets signal transducer and activator of transcription 3 (STAT3) via direct action at the let-7 complementary site. As HBx repressed let-7, and let-7 repressed STAT3, high HBx protein levels result in decreased let-7 and increased STAT3. The authors note that increased STAT3 supports proliferation of HBV-infected cells (369). In addition, because of the prosurvival effects of IL-6 signaling, which acts in part through STAT3, one could speculate the HBx-mediated let-7 repression may have a prosurvival effect by promoting IL-6 signaling. Any such prosurvival effect, along with the demonstrated increase in proliferation, would have to be weighed against the proapoptotic effect of HBx protein.

MicroRNA dysregulation has recently been demonstrated in fatty liver disease, with altered microRNA levels following free-fatty acid treatment and in human NASH liver samples. Human liver samples from patients with metabolic syndrome were grouped into NASH or controls (normal liver histology) and compared by hybridization array for microRNA levels (71). Among the 46 microRNAs with either increased $(n=23)$ or decreased $(n=23)$ expression in NASH livers, several microRNAs previously associated with apoptosis were altered, including decreased miR-26b, miR-122, and miR-145, and increased miR-16, miR-21, miR-24, miR-27b, and miR-34a levels. Diet-induced fatty liver disease in the rat (variations on high fat and high fructose) was associated with alterations in 14 microRNAs, including decreased miR-122, and miR-145 and increased miR-21. Depending on the diet that rats were given, miR-24 was increased or decreased (7). A separate study in rats compared 4-week and 12-week high-fat diet with normal chow, in which the short treatment resulted in steatosis and the longer treatment resulted in steatosis with mild inflammation. MicroRNAs altered between 4-week and 12-week treatment included, among other alterations, decreased miR-145, and increased miR-21, miR-27b, and miR-34a (174). The shared microRNAs may point to conserved alterations in microRNAs from fatty liver disease. We have reported on the antiapoptotic effects of miR-296-5p in Huh-7 cells via targeting the BH3-containing protein PUMA, and found that free-fatty acid treatment decreased miR-296-5p expression, promoting increased PUMA protein and increased lipoapoptosis. This microRNA was also decreased in livers from patients with NASH (60). Whether miR-375 is involved in hepatic lipoapoptosis, similar to a role in endocrine pancreatic lipoapoptosis (224), remains to be determined.

The role of microRNAs in liver fibrosis has received significant attention recently (173). In particular, profiling of microRNAs that are changed during activation of HSCs revealed 12 microRNAs with increased expression and 9 with decreased expression. Because HSC apoptosis hastens resolution of fibrosis, it may be unsurprising that among the micro RNAs that are decreased, several regulate apoptosis, including miR-15b, miR-16, miR-375, and miR-122 (137). Further investigation confirmed that the paired and related miR-15b and miR-16 target Bcl-2 in HSCs and promote apoptosis (138). Multiple studies have implicated miR-29 family members in liver fibrosis $(18,45,142,195,208,269,292,310,404)$. Importantly, induction of liver fibrosis by either carbon tetrachloride or bile duct ligation caused a decrease in miR-29 family member expression and likely results from repression by transforming growth factor- $\beta$, lipopolysaccharide, and NF- $\kappa B$ (292). An additional signal that may contribute to reduced miR-29 expression is Hedgehog-dependent repression (256), with relevance to fibrosis as Hedgehog is activated by bile-duct ligation induced injury (276). Antifibrogenic effects of hepatocyte growth factor and estrogen may be, in part, mediated by miR-29 induction $(208,404)$. The signaling for the miR-15 family and miR-29 family are summarized in Figure 11. In addition to HSC-derived miR-29, hepatocyte miR-29 also contributes to fibrosis, as demonstrated in mice with tissue-specific deletion of 
mir-29b1 29a via Cre recombinase driven by the albumin promoter (195). While miR-29 promotes apoptosis, which would be expected to decrease fibrosis by eliminating matrix producing cells, the antifibrotic effects seem largely due to collagen and matrix metalloproteinase targeting $(292,324)$.

MicroRNA regulation of cell death in the liver represents a new mechanism by which cells can fine-tune expression of proteins that control cell death. By altering the balance of proand antiapoptotic proteins, microRNAs contribute to liver cell death sensitivity, and thus may serve as markers of injury $(323,348,403)$, effectors of death pathways (227), and therapeutic targets (105) in liver disease.

\section{Apoptosis and Hepatobiliary Cancer}

There is a great deal of confusion regarding the role of apoptosis in liver cell cancer. Although evasion of apoptosis is a hallmark of cancer (140), this is only true of established cancers. Indeed, inhibition of cell death is actually protective against cancer development in the liver. The first example of this in a preclinical model was the prevention of HCC in an animal model of HBV-mediated liver cancer using anti-FasL-directed therapy (261). Fausto and co-workers also demonstrated that transgenic expression of Bcl-2 also prevented HCC in a transforming growth factor- $a$-induced genetic mouse model of HCC (279). Along these lines, genetic silencing of caspase 8 prevents hepatocellular cancer development in mice with defective NF- $\kappa B$ signaling (226). In contrast, accentuation of hepatocyte apoptosis with associated compensatory cellular proliferation and inflammation is actually carcinogenic in the liver. For example, hepatocyte genetic deletion of the potent antiapoptotic Bcl-2 protein Mcl-1 is associated with spontaneous hepatocyte apoptosis, cell turnover, inflammation, and hepatocarcinogenesis (361). Deletion of the proapoptotic BH3-only protein PUMA also protects against diethyl nitrosamine (DEN)-induced hepatocarcinogenesis $(22,283)$. Loss of the death receptor Fas/CD95 also inhibits DEN-induced carcinogenesis in the mouse (68). The tumorigenic activity of Fas/CD95 may be mediated by a pathway involving JNK and Jun; however, its proapoptotic activity may also contribute to the development of HCC in this model. Collectively, these data indicate apoptosis with associated compensatory cellular proliferation is carcinogenic in the liver and, conversely, inhibition of apoptosis should protect against the development of liver cell cancer (Fig. 12). These data also help reconcile the conflicting data that molecules identified as prooncogenic mediators in established HCC appear to function as tumor suppressors when genetically deleted from normal hepatocytes (101); deletion of many of these molecules deprives the hepatocyte of potent survival factors, thereby, enabling liver damage which promotes liver cancer.

In contrast to the above comments regarding carcinogenesis, evasion of apoptosis is a hallmark of established HCC and CCA. Indeed, the antiapoptotic Bcl-2 proteins Bcl- $\mathrm{x}_{\mathrm{L}}$ and Mcl-1 are overexpressed in HCC likely due to copy number amplification (27, 318, 334, 335). Whether an inverse relationship exists between expression of these two antiapoptotic proteins, as has been described in other cancers, remains to be determined, but is likely, and suggests that either Bcl- $\mathrm{x}_{\mathrm{L}}$ or Mcl-1 may be responsible for inhibiting apoptosis in this malignancy (372). In contrast, CCA appears to have predominant overexpression of Mcl-1 as a mechanism responsible for its resistance to apoptosis (194). Strategies to circumvent the function and/or expression of these antiapoptotic proteins may be therapeutic in HCC. For example, sorafenib, a tyrosine kinase inhibitor, results in down-regulation of Mcl-1, and navitoclax (ABT-737), a BH3-mimetic, antagonizes Bcl-x $\mathrm{x}_{\mathrm{L}}(365,398)$; the combination of these two drugs has been shown to be highly therapeutic in vitro for HCC (157). Thus, an understanding of the molecular basis for apoptosis resistance may well translate into therapeutic strategies for the treatment of HCC. 


\section{Therapeutic Targets}

Therapy for liver diseases is best directed at the inciting mechanism such as the virus in hepatitis $\mathrm{B}$ or $\mathrm{C}$ related liver disease, or iron or copper removal in genetic hemochromatosis or Wilson's disease, respectively. However, in a large number of liver diseases, the inciting or dominant pathogenic factor remains unclear (e.g., nonalcoholic fatty liver disease, PSC, PBC, etc). In this regard, safe, easy to administer, hepatoprotective compounds would be of clinical value. As liver cell apoptosis is a feature of virtually all liver diseases, an anticell death therapy would be one such strategy to ameliorate human liver diseases. By preventing cell death, liver fibrosis, and its sequelae of cirrhosis and portal hypertension should also be reduced. We have previously highlighted the potential role of caspase, cathepsin B, and JNK inhibitors in liver injury and, therefore, we will not reiterate those concepts here, as little progress has been made with these agents (239). Instead, we will focus on other approaches based on the pathophysiologic concepts described above. In particular, we will suggest key targets which have not yet been exploited. We again note that inhibiting apoptosis and cell turnover in the liver should actually be protective against the development of liver cancer (see above).

$\mathrm{cFLIP}_{\mathrm{L}}$ is a pivotal molecule in regulating death receptor-mediated cell death. Indeed, cFLIP $_{\mathrm{L}}$ blocks apoptosis, necroptosis and cell death by the RIPoptosome $(102,272,343)$. Strategies to increase $\mathrm{cFLIP}_{\mathrm{L}}$ expression should therefore be quite salutary in human liver diseases. Given interest in accentuating apoptosis in human cancers, most investigators have focused on cellular elimination of cFLIP $_{\mathrm{L}}$ as an approach to enhance proapoptotic strategies in cancer therapy. Moreover, increases in T-cell cFLIP $\mathrm{L}_{\mathrm{L}}$ expression blocks Fas-mediated cell death, which may perturb T-cell homeostasis and function $(201,402)$. The augmented expression of $\mathrm{cFLIP}_{\mathrm{L}}$ would optimally be hepatocyte specific; potential therapeutic strategies to accomplish this goal could include use of miRNA antagonists, and modulation of signal transduction pathways to increase $\mathrm{cFLIP}_{\mathrm{L}}$ transcription or inhibit its degradation.

Mcl-1 also appears to be a key antiapoptotic protein in the liver, and its overexpression has been shown to attenuate cholestatic liver injury (179). Conversely, conditional hepatocyte deletion of Mcl-1 in hepatocytes results in spontaneous hepatocyte apoptosis and liver injury $(156,361,375)$. Mcl-1 is a protein highly regulated in cells given its short half-life and high protein turnover, affording multiple avenues to augments its cellular protein levels (116). Increasing Mcl-1 levels could be accomplished by enhancing its transcription, increasing its translation by antagonizing miR-29b, preventing its ubiquitination by E3 ligases, blocking its deubiquitination, or inhibiting its protein degradation by the proteasome (116). Such strategies would optimally also need to be hepatocyte specific. Although Mcl-1 blocks the intrinsic or mitochondrial pathway of cell death, given the cross-talk between the extrinsic and intrinsic pathways of cell death in hepatocytes, Mcl-1 should block cell death by either pathway.

\section{Conclusion}

Here we have strived to present the role of cell death in liver disease, and propose that while apoptosis may not be the root cause of liver diseases, preventing liver cell death would mitigate the pathology and improve health in the majority of disease states. Decreased hepatocyte cell death would mitigate the need for continued regeneration. While the liver is quite famous for its regenerative capacity, in the healthy state very little hepatocyte cell division is seen. The chronic death and replacement of hepatocytes contributes to the proliferative and inflammatory environment in the cirrhotic liver, ultimately resulting in malignancy in some. In acute liver disease, the link between liver injury and loss of liver synthetic, metabolic, and secretory function becomes more pronounced. Here again, 
prevention of hepatocyte cell death would decrease disease severity, allowing for regeneration and restoration of liver function and mass without the need for transplantation. Be it due ethanol, BAs, or xenobiotics, cell death plays a role in their effects. Inflammatory states of the liver have a particularly insidious ability to be self-reinforcing, where inflammation induces cell death, resulting in activation of Kupffer cell-derived cytokines that further amplify the inflammation. As the liver is the first line of defense for detoxification, plays a role in innate immunity, and features prominently in hemostasis and normoglycemia, preventing damage to the various cell types of the liver is an important goal to maintain health not only of the liver, but of its owner.

\section{Acknowledgments}

This work was supported by NIH grants R01 DK41876 and R01 DK63947 (to G. J. Gores), R03 DK092263 (to J. L. Mott), State of Nebraska LB595 Cancer and Smoking Disease Research Program (to J. L. Mott) and the Mayo Foundation. The secretarial assistance of Ms. Courtney Hoover is greatly appreciated.

\section{References}

1. Abu-Amara M, Yang SY, Tapuria N, Fuller B, Davidson B, Seifalian A. Liver ischemia/reperfusion injury: Processes in inflammatory networks-a review. Liver Transplant. 2010; 16:1016-1032.

2. Adachi M, Suematsu S, Kondo T, Ogasawara J, Tanaka T, Yoshida N, Nagata S. Targeted mutation in the Fas gene causes hyperplasia in peripheral lymphoid organs and liver. Nat Genet. 1995; 11:294-300. [PubMed: 7581453]

3. Afford SC, Ahmed-Choudhury J, Randhawa S, Russell C, Youster J, Crosby HA, Eliopoulos A, Hubscher SG, Young LS, Adams DH. CD40 activation-induced, Fas-dependent apoptosis and NFkappaB/AP-1 signaling in human intrahepatic biliary epithelial cells. FASEB J. 2001; 15:23452354. [PubMed: 11689460]

4. Agarwal R, Hennings L, Rafferty TM, Letzig LG, McCullough S, James LP, MacMillan-Crow LA, Hinson JA. Acetaminophen-induced hepatotoxicity and protein nitration in neuronal nitric-oxide synthase knockout mice. J Pharmacol Exp Ther. 2012; 340:134-142. [PubMed: 22001257]

5. Akazawa Y, Gores GJ. Death receptor-mediated liver injury. Semin Liver Dis. 2007; 27:327-338. [PubMed: 17979070]

6. Alabraba EB, Lai V, Boon L, Wigmore SJ, Adams DH, Afford SC. Coculture of human liver macrophages and cholangiocytes leads to CD40-dependent apoptosis and cytokine secretion. Hepatology. 2008; 47:552-562. [PubMed: 17999420]

7. Alisi A, Da Sacco L, Bruscalupi G, Piemonte F, Panera N, De Vito R, Leoni S, Bottazzo GF, Masotti A, Nobili V. Mirnome analysis reveals novel molecular determinants in the pathogenesis of diet-induced nonalcoholic fatty liver disease. Lab Invest. 2011; 91:283-293. [PubMed: 20956972]

8. Altomare E, Leo MA, Lieber CS. Interaction of acute ethanol administration with acetaminophen metabolism and toxicity in rats fed alcohol chronically. Alcohol Clin Exp Res. 1984; 8:405-408. [PubMed: 6385764]

9. Amaral JD, Viana RJ, Ramalho RM, Steer CJ, Rodrigues CM. Bile acids: Regulation of apoptosis by ursodeoxycholic acid. J Lipid Res. 2009; 50:1721-1734. [PubMed: 19417220]

10. Argo CK, Northup PG, Al-Osaimi AM, Caldwell SH. Systematic review of risk factors for fibrosis progression in non-alcoholic steatohep-atitis. J Hepatol. 2009; 51:371-379. [PubMed: 19501928]

11. Aslan JE, You H, Williamson DM, Endig J, Youker RT, Thomas L, Shu H, Du Y, Milewski RL, Brush MH, Possemato A, Sprott K, Fu H, Greis KD, Runckel DN, Vogel A, Thomas G. Akt and 14-3-3 control a PACS-2 homeostatic switch that integrates membrane traffic with TRAILinduced apoptosis. Mol Cell. 2009; 34:497-509. [PubMed: 19481529]

12. Badmann A, Keough A, Kaufmann T, Bouillet P, Brunner T, Corazza N. Role of TRAIL and the pro-apoptotic Bcl-2 homolog Bim in acetaminophen-induced liver damage. Cell Death Dis. 2011; 2:e171. [PubMed: 21654829]

13. Baeck C, Wehr A, Karlmark KR, Heymann F, Vucur M, Gassler N, Huss S, Klussmann S, Eulberg D, Luedde T, Trautwein C, Tacke F. Pharmacological inhibition of the chemokine CCL2 (MCP-1) 
diminishes liver macrophage infiltration and steatohepatitis in chronic hepatic injury. Gut. 2012; 61:416-426. [PubMed: 21813474]

14. Baek D, Villen J, Shin C, Camargo FD, Gygi SP, Bartel DP. The impact of microRNAs on protein output. Nature. 2008; 455:64-71. [PubMed: 18668037]

15. Baines CP, Kaiser RA, Purcell NH, Blair NS, Osinska H, Hambleton MA, Brunskill EW, Sayen MR, Gottlieb RA, Dorn GW, Robbins J, Molkentin JD. Loss of cyclophilin D reveals a critical role for mitochondrial permeability transition in cell death. Nature. 2005; 434:658-662. [PubMed: 15800627]

16. Bajt ML, Knight TR, Lemasters JJ, Jaeschke H. Acetaminophen-induced oxidant stress and cell injury in cultured mouse hepatocytes: Protection by N-acetyl cysteine. Toxicol Sci. 2004; 80:343349. [PubMed: 15115886]

17. Bamboat ZM, Balachandran VP, Ocuin LM, Obaid H, Plitas G, De-Matteo RP. Toll-like receptor 9 inhibition confers protection from liver ischemia-reperfusion injury. Hepatology. 2010; 51:621632. [PubMed: 19902481]

18. Bandyopadhyay S, Friedman RC, Marquez RT, Keck K, Kong B, Icardi MS, Brown KE, Burge CB, Schmidt WN, Wang Y, McCaffrey AP. Hepatitis C virus infection and hepatic stellate cell activation downregulate miR-29: miR-29 overexpression reduces hepatitis $\mathrm{C}$ viral abundance in culture. J Infect Dis. 2011; 203:1753-1762. [PubMed: 21606534]

19. Barton GM, Kagan JC. A cell biological view of Toll-like receptor function: Regulation through compartmentalization. Nat Rev Immunol. 2009; 9:535-542. [PubMed: 19556980]

20. Baskin-Bey ES, Canbay A, Bronk SF, Werneburg N, Guicciardi ME, Nyberg SL, Gores GJ. Cathepsin B inactivation attenuates hepatocyte apoptosis and liver damage in steatotic livers after cold ischemia-warm reperfusion injury. Am J Physiol Gastrointest Liver Physiol. 2005; 288:G396-G402. [PubMed: 15472011]

21. Baskin-Bey ES, Washburn K, Feng S, Oltersdorf T, Shapiro D, Huyghe M, Burgart L, GarrityPark M, van Vilsteren FG, Oliver LK, Rosen CB, Gores GJ. Clinical trial of the pan-caspase inhibitor, IDN-6556, in human liver preservation injury. Am J Transplant. 2007; 7:218-225. [PubMed: 17227570]

22. Baumgartner F, Villunger A. Apoptosis: A barrier against cancer no more? Hepatology. 2011; 54:1121-1124. [PubMed: 21898490]

23. Bendtzen K, Mandrup-Poulsen T, Nerup J, Nielsen JH, Dinarello CA, Svenson M. Cytotoxicity of human pI 7 interleukin-1 for pancreatic islets of Langerhans. Science. 1986; 232:1545-1547. [PubMed: 3086977]

24. Benedetti A, Jezequel AM, Orlandi F. Preferential distribution of apoptotic bodies in acinar zone 3 of normal human and rat liver. J Hepatol. 1988; 7:319-324. [PubMed: 3235800]

25. Benedetti A, Jezequel AM, Orlandi F. A quantitative evaluation of apoptotic bodies in rat liver. Liver. 1988; 8:172-177. [PubMed: 3393066]

26. Benz C, Angermuller S, Tox U, Kloters-Plachky P, Riedel HD, Sauer P, Stremmel W, Stiehl A. Effect of tauroursodeoxycholic acid on bileacid-induced apoptosis and cytolysis in rat hepatocytes. J Hepatol. 1998; 28:99-106. [PubMed: 9537871]

27. Beroukhim R, Mermel CH, Porter D, Wei G, Raychaudhuri S, Donovan J, Barretina J, Boehm JS, Dobson J, Urashima M, Mc Henry KT, Pinchback RM, Ligon AH, Cho YJ, Haery L, Greulich H, Reich M, Winckler W, Lawrence MS, Weir BA, Tanaka KE, Chiang DY, Bass AJ, Loo A, Hoffman C, Prensner J, Liefeld T, Gao Q, Yecies D, Signoretti S, Maher E, Kaye FJ, Sasaki H, Tepper JE, Fletcher JA, Tabernero J, Baselga J, Tsao MS, Demichelis F, Rubin MA, Janne PA, Daly MJ, Nucera C, Levine RL, Ebert BL, Gabriel S, Rustgi AK, Antonescu CR, Ladanyi M, Letai A, Garraway LA, Loda M, Beer DG, True LD, Okamoto A, Pomeroy SL, Singer S, Golub TR, Lander ES, Getz G, Sellers WR, Meyerson M. The landscape of somatic copy-number alteration across human cancers. Nature. 2010; 463:899-905. [PubMed: 20164920]

28. Bertolotti A, Zhang Y, Hendershot LM, Harding HP, Ron D. Dynamic interaction of BiP and ER stress transducers in the unfolded-protein response. Nat Cell Biol. 2000; 2:326-332. [PubMed: 10854322] 
29. Bertrand MJ, Milutinovic S, Dickson KM, Ho WC, Boudreault A, Durkin J, Gillard JW, Jaquith JB, Morris SJ, Barker PA. cIAP1 and cIAP2 facilitate cancer cell survival by functioning as E3 ligases that promote RIP1 ubiquitination. Mol Cell. 2008; 30:689-700. [PubMed: 18570872]

30. Beutler B. Microbe sensing, positive feedback loops, and the pathogenesis of inflammatory diseases. Immunol Rev. 2009; 227:248-263. [PubMed: 19120489]

31. Bhathal PS, Gall JA. Deletion of hyperplastic biliary epithelial cells by apoptosis following removal of the proliferative stimulus. Liver. 1985; 5:311-325. [PubMed: 4088005]

32. Bhogal RH, Curbishley SM, Weston CJ, Adams DH, Afford SC. Reactive oxygen species mediate human hepatocyte injury during hypoxia/reoxygenation. Liver Transpl. 2010; 16:1303-1313. [PubMed: 21031546]

33. Bidere N, Lorenzo HK, Carmona S, Laforge M, Harper F, Dumont C, Senik A. Cathepsin D triggers Bax activation, resulting in selective apoptosis-inducing factor (AIF) relocation in $\mathrm{T}$ lymphocytes entering the early commitment phase to apoptosis. J Biol Chem. 2003; 278:3140131411. [PubMed: 12782632]

34. Bieghs V, Verheyen F, van Gorp PJ, Hendrikx T, Wouters K, Lutjohann D, Gijbels MJ, Febbraio M, Binder CJ, Hofker MH, Shiri-Sverdlov R. Internalization of modified lipids by CD36 and SRA leads to hepatic inflammation and lysosomal cholesterol storage in Kupffer cells. PLoS One. 2012; 7:e34378. [PubMed: 22470565]

35. Bilbao G, Contreras JL, Eckhoff DE, Mikheeva G, Krasnykh V, Douglas JT, Thomas FT, Thomas JM, Curiel DT. Reduction of ischemia-reperfusion injury of the liver by in vivo adenovirusmediated gene transfer of the antiapoptotic Bcl-2 gene. Ann Surg. 1999; 230:185-193. [PubMed: 10450732]

36. Bilzer M, Roggel F, Gerbes AL. Role of Kupffer cells in host defense and liver disease. Liver Int. 2006; 26:1175-1186. [PubMed: 17105582]

37. Blazka ME, Wilmer JL, Holladay SD, Wilson RE, Luster MI. Role of proinflammatory cytokines in acetaminophen hepatotoxicity. Toxicol Appl Pharmacol. 1995; 133:43-52. [PubMed: 7597709]

38. Blomgran R, Zheng L, Stendahl O. Cathepsin-cleaved Bid promotes apoptosis in human neutrophils via oxidative stress-induced lysosomal membrane permeabilization. J Leukoc Biol. 2007; 81:1213-1223. [PubMed: 17264306]

39. Boatright KM, Deis C, Denault JB, Sutherlin DP, Salvesen GS. Activation of caspases-8 and -10 by FLIP(L). Biochem J. 2004; 382:651-657. [PubMed: 15209560]

40. Bochkis IM, Rubins NE, White P, Furth EE, Friedman JR, Kaestner KH. Hepatocyte-specific ablation of Foxa2 alters bile acid homeostasis and results in endoplasmic reticulum stress. Nat Med. 2008; 14:828-836. [PubMed: 18660816]

41. Borghi-Scoazec G, Scoazec JY, Durand F, Bernuau J, Belghiti J, Feldmann G, Henin D, Degott C. Apoptosis after ischemia-reperfusion in human liver allografts. Liver Transpl Surg. 1997; 3:407415. [PubMed: 9346771]

42. Boya P, Andreau K, Poncet D, Zamzami N, Perfettini JL, Metivier D, Ojcius DM, Jaattela M, Kroemer G. Lysosomal membrane permeabilization induces cell death in a mitochondriondependent fashion. J Exp Med. 2003; 197:1323-1334. [PubMed: 12756268]

43. Boya P, Gonzalez-Polo RA, Poncet D, Andreau K, Vieira HL, Roumier T, Perfettini JL, Kroemer G. Mitochondrial membrane permeabilization is a critical step of lysosome-initiated apoptosis induced by hydroxy-chloroquine. Oncogene. 2003; 22:3927-3936. [PubMed: 12813466]

44. Boya P, Kroemer G. Lysosomal membrane permeabilization in cell death. Oncogene. 2008; 27:6434-6451. [PubMed: 18955971]

45. Braconi C, Kogure T, Valeri N, Huang N, Nuovo G, Costinean S, Negrini M, Miotto E, Croce CM, Patel T. microRNA-29 can regulate expression of the long non-coding RNA gene MEG3 in hepatocellular cancer. Oncogene. 2011; 30:4750-4756. [PubMed: 21625215]

46. Bradford BU, Marotto M, Lemasters JJ, Thurman RG. New, simple models to evaluate zonespecific damage due to hypoxia in the perfused rat liver: Time course and effect of nutritional state. J Pharmacol Exp Ther. 1986; 236:263-268. [PubMed: 3941397]

47. Bralet MP, Branchereau S, Brechot C, Ferry N. Cell lineage study in the liver using retroviral mediated gene transfer. Evidence against the streaming of hepatocytes in normal liver. Am J Pathol. 1994; 144:896-905. [PubMed: 8178942] 
48. Brenner C, Grimm S. The permeability transition pore complex in cancer cell death. Oncogene. 2006; 25:4744-4756. [PubMed: 16892087]

49. Burns DM, D'Ambrogio A, Nottrott S, Richter JD. CPEB and two poly(A) polymerases control miR-122 stability and p53 mRNA translation. Nature. 2011; 473:105-108. [PubMed: 21478871]

50. Bursch W, Dusterberg B, Schulte-Hermann R. Growth, regression and cell death in rat liver as related to tissue levels of the hepatomitogen cyproterone acetate. Arch Toxicol. 1986; 59:221-227. [PubMed: 2435263]

51. Caban A, Oczkowicz G, Abdel-Samad O, Cierpka L. Influence of Kupffer cells on the early phase of liver reperfusion. Transpl Proc. 2002; 34:694-697.

52. Caldwell-Kenkel JC, Currin RT, Tanaka Y, Thurman RG, Lemasters JJ. Kupffer cell activation and endothelial cell damage after storage of rat livers: Effects of reperfusion. Hepatology. 1991; 13:83-95. [PubMed: 1988348]

53. Canbay A, Feldstein A, Baskin-Bey E, Bronk SF, Gores GJ. The caspase inhibitor IDN-6556 attenuates hepatic injury andfibrosis inthe bile duct ligated mouse. J Pharmacol Exp Ther. 2004; 308:1191-1196. [PubMed: 14617689]

54. Canbay A, Feldstein AE, Higuchi H, Werneburg N, Grambihler A, Bronk SF, Gores GJ. Kupffer cell engulfment of apoptotic bodies stimulates death ligand and cytokine expression. Hepatology. 2003; 38:1188-1198. [PubMed: 14578857]

55. Canbay A, Friedman S, Gores GJ. Apoptosis: The nexus of liver injury and fibrosis. Hepatology. 2004; 39:273-278. [PubMed: 14767974]

56. Canbay A, Guicciardi ME, Higuchi H, Feldstein A, Bronk SF, Rydzewski R, Taniai M, Gores GJ. Cathepsin B inactivation attenuates hepatic injury and fibrosis during cholestasis. J Clin Invest. 2003; 112:152-159. [PubMed: 12865404]

57. Canbay A, Taimr P, Torok N, Higuchi H, Friedman S, Gores GJ. Apoptotic body engulfment by a human stellate cell line is profibrogenic. Lab Invest. 2003; 83:655-663. [PubMed: 12746475]

58. Cazanave SC, Elmi NA, Akazawa Y, Bronk SF, Mott JL, Gores GJ. CHOP and AP-1 cooperatively mediate PUMA expression during lipoapoptosis. Am J Physiol Gastrointest Liver Physiol. 2010; 299:G236-G243. [PubMed: 20430872]

59. Cazanave SC, Mott JL, Bronk SF, Werneburg NW, Fingas CD, Meng XW, Finnberg N, El-Deiry WS, Kaufmann SH, Gores GJ. Death receptor 5 signaling promotes hepatocyte lipoapoptosis. J Biol Chem. 2011; 286:39336-39348. [PubMed: 21941003]

60. Cazanave SC, Mott JL, Elmi NA, Bronk SF, Masuoka HC, Charlton MR, Gores GJ. A role for miR-296 in the regulation of lipoapoptosis by targeting PUMA. J Lipid Res. 2011; 52:1517-1525. [PubMed: 21633093]

61. Chai J, Du C, Wu JW, Kyin S, Wang X, Shi Y. Structural and biochemical basis of apoptotic activation by Smac/DIABLO. Nature. 2000; 406:855-862. [PubMed: 10972280]

62. Chan FK, Baehrecke EH. RIP3 finds partners in crime. Cell. 2012; 148:17-18. [PubMed: 22265396]

63. Chang J, Nicolas E, Marks D, Sander C, Lerro A, Buendia MA, Xu C, Mason WS, Moloshok T, Bort R, Zaret KS, Taylor JM. miR-122, a mammalian liver-specific microRNA, is processed from her mRNA and may downregulate the high affinity cationic amino acid transporter CAT-1. RNA Biol. 2004; 1:106-113. [PubMed: 17179747]

64. Chang TC, Yu D, Lee YS, Wentzel EA, Arking DE, West KM, Dang CV, Thomas-Tikhonenko A, Mendell JT. Widespread microRNA repression by Myc contributes to tumorigenesis. Nat Genet. 2008; 40:43-50. [PubMed: 18066065]

65. Charlotte F, L'Hermine A, Martin N, Geleyn Y, Nollet M, Gaulard P, Zafrani ES. Immunohistochemical detection of bcl-2 protein in normal and pathological human liver. Am J Pathol. 1994; 144:460-465. [PubMed: 8129031]

66. Chen GY, Nunez G. Sterile inflammation: Sensing and reacting to damage. Nat Rev Immunol. 2010; 10:826-837. [PubMed: 21088683]

67. Chen GY, Tang J, Zheng P, Liu Y. CD24 and Siglec-10 selectively repress tissue damage-induced immune responses. Science. 2009; 323:1722-1725. [PubMed: 19264983] 
68. Chen L, Park SM, Tumanov AV, Hau A, Sawada K, Feig C, Turner JR, Fu YX, Romero IL, Lengyel E, Peter ME. CD95 promotes tumour growth. Nature. 2010; 465:492-496. [PubMed: 20505730]

69. Chen XM, Gores GJ, Paya CV, LaRusso NF. Cryptosporidium parvum induces apoptosis in biliary epithelia by a Fas/Fas ligand-dependent mechanism. Am J Physiol Gastrointest Liver Physiol. 1999; 277:G599-G608.

70. Chen ZJ. Ubiquitination in signaling to and activation of IKK. Immunol Rev. 2012; 246:95-106. [PubMed: 22435549]

71. Cheung O, Puri P, Eicken C, Contos MJ, Mirshahi F, Maher JW, Kellum JM, Min H, Luketic VA, Sanyal AJ. Nonalcoholic steatohepatitis is associated with altered hepatic MicroRNA expression. Hepatology. 2008; 48:1810-1820. [PubMed: 19030170]

72. Cirman T, Oresic K, Mazovec GD, Turk V, Reed JC, Myers RM, Salvesen GS, Turk B. Selective disruption of lysosomes in HeLa cells triggers apoptosis mediated by cleavage of Bid by multiple papain-like lysosomal cathepsins. J Biol Chem. 2004; 279:3578-3587. [PubMed: 14581476]

73. Cohen JI, Roychowdhury S, McMullen MR, Stavitsky AB, Nagy LE. Complement and alcoholic liver disease: Role of C1q in the pathogenesis of ethanol-induced liver injury in mice. Gastroenterology. 2010; 139:664-674. e661. [PubMed: 20416309]

74. Columbano A, Ledda-Columbano GM, Coni PP, Faa G, Liguori C, Santa Cruz G, Pani P. Occurrence of cell death (apoptosis) during the involution of liver hyperplasia. Lab Invest. 1985; 52:670-675. [PubMed: 4010225]

75. Cory S, Adams JM. The Bcl2 family: Regulators of the cellular life-or-death switch. Nat Rev Cancer. 2002; 2:647-656. [PubMed: 12209154]

76. Cursio R, Gugenheim J, Ricci JE, Crenesse D, Rostagno P, Maulon L, Saint-Paul MC, Ferrua B, Auberger AP. A caspase inhibitor fully protects rats against lethal normothermic liver ischemia by inhibition of liver apoptosis. FASEB J. 1999; 13:253-261. [PubMed: 9973313]

77. De Vito R, Alisi A, Masotti A, Ceccarelli S, Panera N, Citti A, Salata M, Valenti L, Feldstein AE, Nobili V. Markers of activated inflammatory cells correlate with severity of liver damage in children with nonalcoholic fatty liver disease. Int J Mol Med. 2012; 30:49-56. [PubMed: 22505182]

78. de Vree JM, Jacquemin E, Sturm E, Cresteil D, Bosma PJ, Aten J, Deleuze JF, Desrochers M, Burdelski M, Bernard O, Oude Elferink RP, Hadchouel M. Mutations in the MDR3 gene cause progressive familial intrahepatic cholestasis. Proc Natl Acad Sci U S A. 1998; 95:282-287. [PubMed: 9419367]

79. De Vree JM, Ottenhoff R, Bosma PJ, Smith AJ, Aten J, Oude Elferink RP. Correction of liver disease by hepatocyte transplantation in a mouse model of progressive familial intrahepatic cholestasis. Gastroenterology. 2000; 119:1720-1730. [PubMed: 11113093]

80. Declercq W, Vanden Berghe T, Vandenabeele P. RIP kinases at the crossroads of cell death and survival. Cell. 2009; 138:229-232. [PubMed: 19632174]

81. Degterev A, Hitomi J, Germscheid M, Ch'en IL, Korkina O, Teng X, Abbott D, Cuny GD, Yuan C, Wagner G, Hedrick SM, Gerber SA, Lugovskoy A, Yuan J. Identification of RIP1 kinase as a specific cellular target of necrostatins. Nat Chem Biol. 2008; 4:313-321. [PubMed: 18408713]

82. DeLeve LD. Hepatic microvasculature in liver injury. Semin Liver Dis. 2007; 27:390-400. [PubMed: 17979075]

83. Diehl L, Schurich A, Grochtmann R, Hegenbarth S, Chen L, Knolle PA. Tolerogenic maturation of liver sinusoidal endothelial cells promotes B7-homolog 1-dependent CD8+ T cell tolerance. Hepatology. 2008; 47:296-305. [PubMed: 17975811]

84. Dixon LJ, Berk M, Thapaliya S, Papouchado BG, Feldstein AE. Caspase-1-mediated regulation of fibrogenesis in diet-induced steatohepatitis. Lab Invest. 2012; 92:713-723. [PubMed: 22411067]

85. Dolganiuc A, Szabo G. Dendritic cells in hepatitis C infection: Can they (help) win the battle? J Gastroenterol. 2011; 46:432-447. [PubMed: 21327958]

86. Droga-Mazovec G, Bojic L, Petelin A, Ivanova S, Romih R, Repnik U, Salvesen GS, Stoka V, Turk V, Turk B. Cysteine cathepsins trigger caspase-dependent cell death through cleavage of bid and antiapoptotic Bcl-2 homologues. J Biol Chem. 2008; 283:19140-19150. [PubMed: 18469004] 
87. Eckelman BP, Salvesen GS, Scott FL. Human inhibitor of apoptosis proteins: Why XIAP is the black sheep of the family. EMBO Rep. 2006; 7:988-994. [PubMed: 17016456]

88. Eguchi K, Manabe I, Oishi-Tanaka Y, Ohsugi M, Kono N, Ogata F, Yagi N, Ohto U, Kimoto M, Miyake K, Tobe K, Arai H, Kadowaki T, Nagai R. Saturated fatty acid and TLR signaling link beta cell dysfunction and islet inflammation. Cell Metab. 2012; 15:518-533. [PubMed: 22465073]

89. Eichhorst ST. Modulation of apoptosis as a target for liver disease. Expert Opin Ther Tar. 2005; 9:83-99.

90. Elferink RP, Tytgat GN, Groen AK. Hepatic canalicular membrane 1: The role of mdr2 Pglycoprotein in hepatobiliary lipid transport. FASEB J. 1997; 11:19-28. [PubMed: 9034162]

91. Elliott MR, Chekeni FB, Trampont PC, Lazarowski ER, Kadl A, Walk SF, Park D, Woodson RI, Ostankovich M, Sharma P, Lysiak JJ, Harden TK, Leitinger N, Ravichandran KS. Nucleotides released by apoptotic cells act as a find-me signal to promote phagocytic clearance. Nature. 2009; 461:282-286. [PubMed: 19741708]

92. Faouzi S, Burckhardt BE, Hanson JC, Campe CB, Schrum LW, Rippe RA, Maher JJ. Anti-Fas induces hepatic chemokines and promotes inflammation by an NF-kappa B-independent, caspase-3-dependent pathway. J Biol Chem. 2001; 276:49077-49082. [PubMed: 11602613]

93. Faubion WA, Gores GJ. Death receptors in liver biology and pathobiology. Hepatology. 1999; 29:1-4. [PubMed: 9862841]

94. Faubion WA, Guicciardi ME, Miyoshi H, Bronk SF, Roberts PJ, Svingen PA, Kaufmann SH, Gores GJ. Toxic bile salts induce rodent hepatocyte apoptosis via direct activation of Fas. J Clin Invest. 1999; 103:137-145. [PubMed: 9884343]

95. Fava G, Glaser S, Francis H, Alpini G. The immunophysiology of biliary epithelium. Semin Liver Dis. 2005; 25:251-264. [PubMed: 16143942]

96. Fehrenbacher N, Bastholm L, Kirkegaard-Sorensen T, Rafn B, Bottzauw T, Nielsen C, Weber E, Shirasawa S, Kallunki T, Jaattela M. Sensitization to the lysosomal cell death pathway by oncogene-induced down-regulation of lysosome-associated membrane proteins 1 and 2. Cancer Res. 2008; 68:6623-6633. [PubMed: 18701486]

97. Fehrenbacher N, Gyrd-Hansen M, Poulsen B, Felbor U, Kallunki T, Boes M, Weber E, Leist M, Jaattela M. Sensitization to the lysosomal cell death pathway upon immortalization and transformation. Cancer Res. 2004; 64:5301-5310. [PubMed: 15289336]

98. Fehrenbacher N, Jaattela M. Lysosomes as targets for cancer therapy. Cancer Res. 2005; 65:29932995. [PubMed: 15833821]

99. Feldstein AE, Gores GJ. An apoptosis biomarker goes to the HCV clinic. Hepatology. 2004; 40:1044-1046. [PubMed: 15486920]

100. Feldstein AE, Werneburg NW, Canbay A, Guicciardi ME, Bronk SF, Rydzewski R, Burgart LJ, Gores GJ. Free fatty acids promote hepatic lipotoxicity by stimulating TNF-alpha expression via a lysosomal pathway. Hepatology. 2004; 40:185-194. [PubMed: 15239102]

101. Feng GS. Conflicting roles of molecules in hepatocarcinogenesis: Paradigm or paradox. Cancer cell. 2012; 21:150-154. [PubMed: 22340589]

102. Feoktistova M, Geserick P, Kellert B, Dimitrova DP, Langlais C, Hupe M, Cain K, MacFarlane M, Hacker G, Leverkus M. cIAPs block Ripoptosome formation, a RIP1/caspase-8 containing intracellular cell death complex differentially regulated by cFLIP isoforms. Mol Cell. 2011; 43:449-463. [PubMed: 21737330]

103. Festi D, Montagnani M, Azzaroli F, Lodato F, Mazzella G, Roda A, Di Biase AR, Roda E, Simoni P, Colecchia A. Clinical efficacy and effectiveness of ursodeoxycholic acid in cholestatic liver diseases. Curr Clin Pharmacol. 2007; 2:155-177. [PubMed: 18690863]

104. Fickert P, Trauner M, Fuchsbichler A, Zollner G, Wagner M, Marschall HU, Zatloukal K, Denk H. Oncosis represents the main type of cell death in mouse models of cholestasis. J Hepatol. 2005; 42:378-385. [PubMed: 15710221]

105. Filipowicz W, Grosshans H. The liver-specific microRNA miR-122: Biology and therapeutic potential. Prog Drug Res. 2011; 67:221-238. [PubMed: 21141732]

106. Fiorucci S, Cipriani S, Mencarelli A, Baldelli F, Bifulco G, Zampella A. Farnesoid X receptor agonist for the treatment of liver and metabolic disorders: Focus on 6-ethyl-CDCA. Mini Rev Med Chem. 2011; 11:753-762. [PubMed: 21707532] 
107. Foghsgaard L, Wissing D, Mauch D, Lademann U, Bastholm L, Boes M, Elling F, Leist M, Jaattela M. Cathepsin B acts as a dominant execution protease in tumor cell apoptosis induced by tumor necrosis factor. J Cell Biol. 2001; 153:999-1010. [PubMed: 11381085]

108. Galluzzi L, Kroemer G. Necroptosis: A specialized pathway of programmed necrosis. Cell. 2008; 135:1161-1163. [PubMed: 19109884]

109. Galluzzi L, Vitale I, Abrams JM, Alnemri ES, Baehrecke EH, Blagosklonny MV, Dawson TM, Dawson VL, El-Deiry WS, Fulda S, Gottlieb E, Green DR, Hengartner MO, Kepp O, Knight RA, Kumar S, Lipton SA, Lu X, Madeo F, Malorni W, Mehlen P, Nunez G, Peter ME, Piacentini M, Rubinsztein DC, Shi Y, Simon HU, Vandenabeele P, White E, Yuan J, Zhivotovsky B, Melino G, Kroemer G. Molecular definitions of cell death subroutines: Recommendations of the Nomenclature Committee on Cell Death 2012. Cell Death Differ. 2012; 19:107-120. [PubMed: 21760595]

110. Ganten TM, Haas TL, Sykora J, Stahl H, Sprick MR, Fas SC, Krueger A, Weigand MA, GrosseWilde A, Stremmel W, Krammer PH, Walczak H. Enhanced caspase-8 recruitment to and activation at the DISC is critical for sensitisation of human hepatocellular carcinoma cells to TRAIL-induced apoptosis by chemotherapeutic drugs. Cell Death Differ. 2004; 11(Suppl 1):S86-S96. [PubMed: 15105837]

111. Gao B, Jeong WI, Tian Z. Liver: An organ with predominant innate immunity. Hepatology. 2008; 47:729-736. [PubMed: 18167066]

112. Gao B, Seki E, Brenner DA, Friedman S, Cohen JI, Nagy L, Szabo G, Zakhari S. Innate immunity in alcoholic liver disease. Am J Physiol Gastrointest Liver Physiol. 2011; 300:G516G525. [PubMed: 21252049]

113. Gardner BM, Walter P. Unfolded proteins are Ire1-activating ligands that directly induce the unfolded protein response. Science. 2011; 333:1891-1894. [PubMed: 21852455]

114. Gonzalez FJ, Yu AM. Cytochrome P450 and xenobiotic receptor humanized mice. Ann Rev Pharmacol. 2006; 46:41-64.

115. Gores GJ, Herman B, Lemasters JJ. Plasma membrane bleb formation and rupture: A common feature of hepatocellular injury. Hepatology. 1990; 11:690-698. [PubMed: 2184116]

116. Gores GJ, Kaufmann SH. Selectively targeting Mcl-1 for the treatment of acute myelogenous leukemia and solid tumors. Gene Dev. 2012; 26:305-311. [PubMed: 22345513]

117. Gores GJ, Nieminen AL, Fleishman KE, Dawson TL, Herman B, Lemasters JJ. Extracellular acidosis delays onset of cell death in ATP-depleted hepatocytes. Am J Physiol. 1988; 255:C315C322. [PubMed: 3421314]

118. Graf D, Kurz AK, Reinehr R, Fischer R, Kircheis G, Haussinger D. Prevention of bile acidinduced apoptosis by betaine in rat liver. Hepatology. 2002; 36:829-839. [PubMed: 12297830]

119. Grasl-Kraupp B, Rossmanith W, Ruttkay-Nedecky B, Mullauer L, Kammerer B, Bursch W, Schulte-Hermann R. Levels of transforming growth factor beta and transforming growth factor beta receptors in rat liver during growth, regression by apoptosis and neoplasia. Hepatology. 1998; 28:717-726. [PubMed: 9731564]

120. Gregor MF, Yang L, Fabbrini E, Mohammed BS, Eagon JC, Hotamisligil GS, Klein S. Endoplasmic reticulum stress is reduced in tissues of obese subjects after weight loss. Diabetes. 2009; 58:693-700. [PubMed: 19066313]

121. Gregory C. Cell biology: Sent by the scent of death. Nature. 2009; 461:181-182. [PubMed: 19741694]

122. Gross O, Thomas CJ, Guarda G, Tschopp J. The inflammasome: An integrated view. Immunol Rev. 2011; 243:136-151. [PubMed: 21884173]

123. Guebre-Xabier M, Yang S, Lin HZ, Schwenk R, Krzych U, Diehl AM. Altered hepatic lymphocyte subpopulations in obesity-related murine fatty livers: Potential mechanism for sensitization to liver damage. Hepatology. 2000; 31:633-640. [PubMed: 10706553]

124. Guicciardi ME, Bronk SF, Werneburg NW, Gores GJ. cFLIPL prevents TRAIL-induced apoptosis of hepatocellular carcinoma cells by inhibiting the lysosomal pathway of apoptosis. Am J Physiol Gastrointest Liver Physiol. 2007; 292:G1337-G1346. [PubMed: 17272514] 
125. Guicciardi ME, Bronk SF, Werneburg NW, Yin XM, Gores GJ. Bid is upstream of lysosomemediated caspase 2 activation in tumor necrosis factor alpha-induced hepatocyte apoptosis. Gastroenterology. 2005; 129:269-284. [PubMed: 16012953]

126. Guicciardi ME, Deussing J, Miyoshi H, Bronk SF, Svingen PA, Peters C, Kaufmann SH, Gores GJ. Cathepsin B contributes to TNF-alpha-mediated hepatocyte apoptosis by promoting mitochondrial release of cytochrome c. J Clin Invest. 2000; 106:1127-1137. [PubMed: 11067865]

127. Guicciardi, ME.; Faubion, WA.; Bronk, SF.; Roberts, PJ.; Gores, GJ. Mechanisms of bile acidinduced cell death. In: Andus, GR.; Schlottmann, K.; Frick, E.; Scholmerich, J.; Adler, G.; Schmiegel, W.; Zeitz, M., editors. Cytokines and Cell Homeostasis in the Gastrointestinal Tract. Kluwer Acad; Dordrecht, Boston, London: 2000. p. 284-289.

128. Guicciardi ME, Gores GJ. Bile acid-mediated hepatocyte apoptosis and cholestatic liver disease. Dig Liver Dis. 2002; 34:387-392. [PubMed: 12132783]

129. Guicciardi ME, Gores GJ. Apoptosis: A mechanism of acute and chronic liver injury. Gut. 2005; 54:1024-1033. [PubMed: 15951554]

130. Guicciardi ME, Gores GJ. Life and death by death receptors. FASEB J. 2009; 23:1625-1637. [PubMed: 19141537]

131. Guicciardi ME, Leist M, Gores GJ. Lysosomes in cell death. Oncogene. 2004; 23:2881-2890. [PubMed: 15077151]

132. Guicciardi ME, Miyoshi H, Bronk SF, Gores GJ. Cathepsin B knockout mice are resistant to tumor necrosis factor-alpha-mediated hepatocyte apoptosis and liver injury: Implications for therapeutic applications. Am J Pathol. 2001; 159:2045-2054. [PubMed: 11733355]

133. Guicciardi ME, Mott JL, Bronk SF, Kurita S, Fingas CD, Gores GJ. Cellular inhibitor of apoptosis 1 (cIAP-1) degradation by caspase 8 during TNF-related apoptosis-inducing ligand (TRAIL)-induced apoptosis. Exp Cell Res. 2011; 317:107-116. [PubMed: 20951133]

134. Gujral JS, Liu J, Farhood A, Jaeschke H. Reduced oncotic necrosis in Fas receptor-deficient C57BL/6J-lpr mice after bile duct ligation. Hepatology. 2004; 40:998-1007. [PubMed: 15382126]

135. Gunawan BK, Liu ZX, Han D, Hanawa N, Gaarde WA, Kaplowitz N. c-Jun N-terminal kinase plays a major role in murine acetaminophen hepatotoxicity. Gastroenterology. 2006; 131:165178. [PubMed: 16831600]

136. Gunther C, Martini E, Wittkopf N, Amann K, Weigmann B, Neumann H, Waldner MJ, Hedrick SM, Tenzer S, Neurath MF, Becker C. Caspase-8 regulates TNF-alpha-induced epithelial necroptosis and terminal ileitis. Nature. 2011; 477:335-339. [PubMed: 21921917]

137. Guo CJ, Pan Q, Cheng T, Jiang B, Chen GY, Li DG. Changes in microRNAs associated with hepatic stellate cell activation status identify signaling pathways. FEBS J. 2009; 276:5163-5176. [PubMed: 19674103]

138. Guo CJ, Pan Q, Li DG, Sun H, Liu BW. miR-15b and miR-16 are implicated in activation of the rat hepatic stellate cell: An essential role for apoptosis. J Hepatol. 2009; 50:766-778. [PubMed: 19232449]

139. Gyrd-Hansen M, Meier P. IAPs: From caspase inhibitors to modulators of NF-kappaB, inflammation and cancer. Nat Rev Cancer. 2010; 10:561-574. [PubMed: 20651737]

140. Hanahan D, Weinberg RA. Hallmarks of cancer: The next generation. Cell. 2011; 144:646-674. [PubMed: 21376230]

141. Hanawa N, Shinohara M, Saberi B, Gaarde WA, Han D, Kaplowitz N. Role of JNK translocation to mitochondria leading to inhibition of mitochondria bioenergetics in acetaminophen-induced liver injury. J Biol Chem. 2008; 283:13565-13577. [PubMed: 18337250]

142. Hand NJ, Horner AM, Master ZR, Boateng LA, LeGuen C, Uvaydova M, Friedman JR. MicroRNA profiling identifies miR-29 as a regulator of disease-associated pathways in experimental biliary atresia. J Pediatr Gastroenterol Nutr. 2012; 54:186-192. [PubMed: 22167021]

143. Hand NJ, Master ZR, Le Lay J, Friedman JR. Hepatic function is preserved in the absence of mature microRNAs. Hepatology. 2009; 49:618-626. [PubMed: 19127519] 
144. Hanschen M, Zahler S, Krombach F, Khandoga A. Reciprocal activation between CD4+ T cells and Kupffer cells during hepatic ischemia-reperfusion. Transplantation. 2008; 86:710-718. [PubMed: 18791453]

145. Harada K, Ozaki S, Gershwin ME, Nakanuma Y. Enhanced apoptosis relates to bile duct loss in primary biliary cirrhosis. Hepatology. 1997; 26:1399-1405. [PubMed: 9397977]

146. Hatano E. Tumor necrosis factor signaling in hepatocyte apoptosis. J Gastroenterol Hepatol. 2007; 22(Suppl 1):S43-S44. [PubMed: 17567463]

147. Heinrich M, Neumeyer J, Jakob M, Hallas C, Tchikov V, Winoto-Morbach S, Wickel M, Schneider-Brachert W, Trauzold A, Hethke A, Schutze S. Cathepsin D links TNF-induced acid sphingomyelinase to Bid-mediated caspase-9 and -3 activation. Cell Death Differ. 2004; 11:550 563. [PubMed: 14739942]

148. Heinrich M, Wickel M, Schneider-Brachert W, Sandberg C, Gahr J, Schwandner R, Weber T, Saftig P, Peters C, Brunner J, Kronke M, Schutze S. Cathepsin D targeted by acid sphingomyelinase-derived ceramide. EMBO J. 1999; 18:5252-5263. [PubMed: 10508159]

149. Henao-Mejia J, Elinav E, Jin C, Hao L, Mehal WZ, Strowig T, Thaiss CA, Kau AL, Eisenbarth SC, Jurczak MJ, Camporez JP, Shulman GI, Gordon JI, Hoffman HM, Flavell RA. Inflammasome-mediated dysbiosis regulates progression of NAFLD and obesity. Nature. 2012; 482:179-185. [PubMed: 22297845]

150. Hetz C, Martinon F, Rodriguez D, Glimcher LH. The unfolded protein response: Integrating stress signals through the stress sensor IRE1alpha. Physiol Rev. 2011; 91:1219-1243. [PubMed: 22013210]

151. Higuchi H, Bronk SF, Taniai M, Canbay A, Gores GJ. Cholestasis increases tumor necrosis factor-related apoptotis-inducing lig-and (TRAIL)-R2/DR5 expression and sensitizes the liver to TRAIL-mediated cytotoxicity. J Pharmacol Exp Ther. 2002; 303:461-467. [PubMed: 12388624]

152. Higuchi H, Grambihler A, Canbay A, Bronk SF, Gores GJ. Bile acids up-regulate death receptor 5/TRAIL-receptor 2 expression via a c-Jun N-terminal kinase-dependent pathway involving Sp1. J Biol Chem. 2004; 279:51-60. [PubMed: 14561739]

153. Higuchi H, Yoon JH, Grambihler A, Werneburg N, Bronk SF, Gores GJ. Bile acids stimulate cFLIP phosphorylation enhancing TRAIL-mediated apoptosis. J Biol Chem. 2003; 278:454-461. [PubMed: 12407100]

154. Hikita H, Kodama T, Shimizu S, Li W, Shigekawa M, Tanaka S, Hosui A, Miyagi T, Tatsumi T, Kanto T, Hiramatsu N, Morii E, Hayashi N, Takehara T. Bak deficiency inhibits liver carcinogenesis: A causal link between apoptosis and carcinogenesis. J Hepatol. 2012; 57:92-100. [PubMed: 22414765]

155. Hikita H, Takehara T, Kodama T, Shimizu S, Hosui A, Miyagi T, Tatsumi T, Ishida H, Ohkawa K, Li W, Kanto T, Hiramatsu N, Hennighausen L, Yin XM, Hayashi N. BH3-only protein bid participates in the Bcl-2 network in healthy liver cells. Hepatology. 2009; 50:1972-1980. [PubMed: 19839062]

156. Hikita H, Takehara T, Shimizu S, Kodama T, Li W, Miyagi T, Hosui A, Ishida H, Ohkawa K, Kanto T, Hiramatsu N, Yin XM, Hennighausen L, Tatsumi T, Hayashi N. Mcl-1 and Bcl-xL cooperatively maintain integrity of hepatocytes in developing and adult murine liver. Hepatology. 2009; 50:1217-1226. [PubMed: 19676108]

157. Hikita H, Takehara T, Shimizu S, Kodama T, Shigekawa M, Iwase K, Hosui A, Miyagi T, Tatsumi T, Ishida H, Li W, Kanto T, Hiramatsu N, Hayashi N. The Bcl-xL inhibitor, ABT-737, efficiently induces apoptosis and suppresses growth of hepatoma cells in combination with sorafenib. Hepatology. 2010; 52:1310-1321. [PubMed: 20799354]

158. Hines IN, Wheeler MD. Recent advances in alcoholic liver disease III. Role of the innate immune response in alcoholic hepatitis. Am J Physiol Gastrointest Liver Physiol. 2004; 287:G310-G314. [PubMed: 15246965]

159. Hoglen NC, Anselmo DM, Katori M, Kaldas M, Shen XD, Valentino KL, Lassman C, Busuttil RW, Kupiec-Weglinski JW, Farmer DG. A caspase inhibitor, IDN-6556, ameliorates early hepatic injury in an ex vivo rat model of warm and cold ischemia. Liver Transpl. 2007; 13:361366. [PubMed: 17318854] 
160. Hoglen NC, Hirakawa BP, Fisher CD, Weeks S, Srinivasan A, Wong AM, Valentino KL, Tomaselli KJ, Bai X, Karanewsky DS, Contreras PC. Characterization of the caspase inhibitor IDN-1965 in a model of apoptosis-associated liver injury. J Pharmacol Exp Ther. 2001; 297:811818. [PubMed: 11303074]

161. Horvath B, Magid L, Mukhopadhyay P, Batkai S, Rajesh M, Park O, Tanchian G, Gao RY, Goodfellow CE, Glass M, Mechoulam R, Pacher P. A new cannabinoid CB2 receptor agonist HU-910 attenuates oxidative stress, inflammation and cell death associated with hepatic ischaemia/reperfusion injury. Br J Pharmacol. 2012; 165:2462-2478. [PubMed: 21449982]

162. Hotchkiss RS, Strasser A, McDunn JE, Swanson PE. Cell death. N Engl J Med. 2009; 361:15701583. [PubMed: 19828534]

163. Hughes MA, Harper N, Butterworth M, Cain K, Cohen GM, MacFarlane M. Reconstitution of the death-inducing signaling complex reveals a substrate switch that determines CD95-mediated death or survival. Mol Cell. 2009; 35:265-279. [PubMed: 19683492]

164. Hunter AM, LaCasse EC, Korneluk RG. The inhibitors of apoptosis (IAPs) as cancer targets. Apoptosis. 2007; 12:1543-1568. [PubMed: 17573556]

165. Hur KY, So JS, Ruda V, Frank-Kamenetsky M, Fitzgerald K, Koteliansky V, Iwawaki T, Glimcher LH, Lee AH. IRE1alpha activation protects mice against acetaminophen-induced hepatotoxicity. J Exp Med. 2012; 209:307-318. [PubMed: 22291093]

166. Ikner A, Ashkenazi A. TWEAK induces apoptosis through a death-signaling complex comprising receptor-interacting protein 1 (RIP1), Fas-associated death domain (FADD), and caspase-8. J Biol Chem. 2011; 286:21546-21554. [PubMed: 21525013]

167. Imaeda AB, Watanabe A, Sohail MA, Mahmood S, Mohamadnejad M, Sutterwala FS, Flavell RA, Mehal WZ. Acetaminophen-induced hepatotoxicity in mice is dependent on Tlr9 and the Nalp3 inflammasome. J Clin Invest. 2009; 119:305-314. [PubMed: 19164858]

168. Ishida Y, Kondo T, Ohshima T, Fujiwara H, Iwakura Y, Mukaida N. A pivotal involvement of IFN-gamma in the pathogenesis of acetaminophen-induced acute liver injury. FASEB J. 2002; 16:1227-1236. [PubMed: 12153990]

169. Jaeschke H, Lemasters JJ. Apoptosis versus oncotic necrosis in hepatic ischemia/reperfusion injury. Gastroenterology. 2003; 125:1246-1257. [PubMed: 14517806]

170. Jaeschke H, Woolbright BL. Current strategies to minimize hepatic ischemia-reperfusion injury by targeting reactive oxygen species. Transplant Rev. 2012; 26:103-114.

171. Jancova P, Anzenbacher P, Anzenbacherova E. Phase II drug metabolizing enzymes. Biomed Pap. 2010; 154:103-116.

172. Ji C, Mehrian-Shai R, Chan C, Hsu YH, Kaplowitz N. Role of CHOP in hepatic apoptosis in the murine model of intragastric ethanol feeding. Alcohol Clin Exp Res. 2005; 29:1496-1503. [PubMed: 16131858]

173. Jiang X, Tsitsiou E, Herrick SE, Lindsay MA. MicroRNAs and the regulation of fibrosis. FEBS J. 2010; 277:2015-2021. [PubMed: 20412055]

174. Jin X, Chen YP, Kong M, Zheng L, Yang YD, Li YM. Transition from hepatic steatosis to steatohepatitis: Unique microRNA patterns and potential downstream functions and pathways. J Gastroenterol Hepatol. 2012; 27:331-340. [PubMed: 21793903]

175. Jopling CL, Yi M, Lancaster AM, Lemon SM, Sarnow P. Modulation of hepatitis C virus RNA abundance by a liver-specific MicroRNA. Science. 2005; 309:1577-1581. [PubMed: 16141076]

176. Jost PJ, Grabow S, Gray D, McKenzie MD, Nachbur U, Huang DC, Bouillet P, Thomas HE, Borner C, Silke J, Strasser A, Kaufmann T. XIAP discriminates between type I and type II FASinduced apoptosis. Nature. 2009; 460:1035-1039. [PubMed: 19626005]

177. Joza N, Susin SA, Daugas E, Stanford WL, Cho SK, Li CY, Sasaki T, Elia AJ, Cheng HY, Ravagnan L, Ferri KF, Zamzami N, Wakeham A, Hakem R, Yoshida H, Kong YY, Mak TW, Zuniga-Pflucker JC, Kroemer G, Penninger JM. Essential role of the mitochondrial apoptosisinducing factor in programmed cell death. Nature. 2001; 410:549-554. [PubMed: 11279485]

178. Kagedal K, Zhao M, Svensson I, Brunk UT. Sphingosine-induced apoptosis is dependent on lysosomal proteases. Biochem J. 2001; 359:335-343. [PubMed: 11583579] 
179. Kahraman A, Mott JL, Bronk SF, Werneburg NW, Barreyro FJ, Guicciardi ME, Akazawa Y, Braley K, Craig RW, Gores GJ. Overexpression of mcl-1 attenuates liver injury and fibrosis in the bile duct-ligated mouse. Digest Dis Sci. 2009; 54:1908-1917. [PubMed: 19051025]

180. Kaiser WJ, Upton JW, Long AB, Livingston-Rosanoff D, Daley-Bauer LP, Hakem R, Caspary T, Mocarski ES. RIP3 mediates the embryonic lethality of caspase-8-deficient mice. Nature. 2011; 471:368-372. [PubMed: 21368762]

181. Kaplowitz N. Cell death at the millennium. Implications for liver diseases. Clin Liver Dis. 2000; 4:1-23. v. [PubMed: 11232179]

182. Kaplowitz N. Mechanisms of liver cell injury. J Hepatol. 2000; 32:39-47. [PubMed: 10728793]

183. Katoh T, Sakaguchi Y, Miyauchi K, Suzuki T, Kashiwabara S, Baba T. Selective stabilization of mammalian microRNAs by $3^{\prime}$ adenylation mediated by the cytoplasmic poly(A) polymerase GLD-2. Genes Dev. 2009; 23:433-438. [PubMed: 19240131]

184. Kaufmann T, Jost PJ, Pellegrini M, Puthalakath H, Gugasyan R, Gerondakis S, Cretney E, Smyth MJ, Silke J, Hakem R, Bouillet P, Mak TW, Dixit VM, Strasser A. Fatal hepatitis mediated by tumor necrosis factor TNFalpha requires caspase-8 and involves the BH3-only proteins Bid and Bim. Immunity. 2009; 30:56-66. [PubMed: 19119023]

185. Kennedy S, Rettinger S, Flye MW, Ponder KP. Experiments in transgenic mice show that hepatocytes are the source for postnatal liver growth and do not stream. Hepatology. 1995; 22:160-168. [PubMed: 7541385]

186. Kim H, Tu HC, Ren D, Takeuchi O, Jeffers JR, Zambetti GP, Hsieh JJ, Cheng EH. Stepwise activation of BAX and BAK by tBID, BIM, and PUMA initiates mitochondrial apoptosis. Mol Cell. 2009; 36:487-499. [PubMed: 19917256]

187. Kim JS, He L, Qian T, Lemasters JJ. Role of the mitochondrial permeability transition in apoptotic and necrotic death after ischemia/reperfusion injury to hepatocytes. Curr Mol Med. 2003; 3:527-535. [PubMed: 14527084]

188. Kim JS, Qian T, Lemasters JJ. Mitochondrial permeability transition in the switch from necrotic to apoptotic cell death in ischemic rat hepatocytes. Gastroenterology. 2003; 124:494-503. [PubMed: 12557154]

189. Kim JS, Wang JH, Lemasters JJ. Mitochondrial permeability transition in rat hepatocytes after anoxia/reoxygenation: Role of $\mathrm{Ca}^{2+}$-dependent mitochondrial formation of reactive oxygen species. Am J Physiol Gastrointest Liver Physiol. 2012; 302:G723-G731. [PubMed: 22241863]

190. Kirkegaard T, Jaattela M. Lysosomal involvement in cell death and cancer. Biochim Biophys Acta. 2009; 1793:746-754. [PubMed: 18948147]

191. Klaassen CD, Aleksunes LM. Xenobiotic, bile acid, and cholesterol transporters: Function and regulation. Pharmacol Rev. 2010; 62:1-96. [PubMed: 20103563]

192. Knight TR, Jaeschke H. Acetaminophen-induced inhibition of Fas receptor-mediated liver cell apoptosis: Mitochondrial dysfunction versus glutathione depletion. Toxicol Appl Pharm. 2002; 181:133-141.

193. Knudson CM, Tung KS, Tourtellotte WG, Brown GA, Korsmeyer SJ. Bax-deficient mice with lymphoid hyperplasia and male germ cell death. Science. 1995; 270:96-99. [PubMed: 7569956]

194. Kobayashi S, Werneburg NW, Bronk SF, Kaufmann SH, Gores GJ. Interleukin-6 contributes to Mcl-1 up-regulation and TRAIL resistance via an Akt-signaling pathway in cholangiocarcinoma cells. Gastroenterology. 2005; 128:2054-2065. [PubMed: 15940637]

195. Kogure T, Costinean S, Yan I, Braconi C, Croce C, Patel T. Hepatic miR-29ab1 expression modulates chronic hepatic injury. J Cell Mol Med. 2012; 16:2647-2654. [PubMed: 22469499]

196. Kohli V, Selzner M, Madden JF, Bentley RC, Clavien PA. Endothelial cell and hepatocyte deaths occur by apoptosis after ischemia-reperfusion injuryin the rat liver. Transplantation. 1999; 67:1099-1105. [PubMed: 10232558]

197. Kon K, Kim JS, Jaeschke H, Lemasters JJ. Mitochondrial permeability transition in acetaminophen-induced necrosis and apoptosis of cultured mouse hepatocytes. Hepatology. 2004; 40:1170-1179. [PubMed: 15486922]

198. Kono H, Fujii H, Ogiku M, Hosomura N, Amemiya H, Tsuchiya M, Hara M. Role of IL-17A in neutrophil recruitment and hepatic injury after warm ischemia-reperfusion mice. J Immunol. 2011; 187:4818-4825. [PubMed: 21949019] 
199. Kota J, Chivukula RR, O'Donnell KA, Wentzel EA, Montgomery CL, Hwang HW, Chang TC, Vivekanandan P, Torbenson M, Clark KR, Mendell JR, Mendell JT. Therapeutic microRNA delivery suppresses tumorigenesis in a murine liver cancer model. Cell. 2009; 137:1005-1017. [PubMed: 19524505]

200. Kozutsumi Y, Segal M, Normington K, Gething MJ, Sambrook J. The presence of malfolded proteins in the endoplasmic reticulum signals the induction of glucose-regulated proteins. Nature. 1988; 332:462-464. [PubMed: 3352747]

201. Krammer PH, Arnold R, Lavrik IN. Life and death in peripheral T cells. Nat Rev Immunol. 2007; 7:532-542. [PubMed: 17589543]

202. Kroemer G, Galluzzi L, Brenner C. Mitochondrial membrane perme-abilization in cell death. Physiol Rev. 2007; 87:99-163. [PubMed: 17237344]

203. Krutzfeldt J, Rajewsky N, Braich R, Rajeev KG, Tuschl T, Manoharan M, Stoffel M. Silencing of microRNAs in vivo with 'antagomirs'. Nature. 2005; 438:685-689. [PubMed: 16258535]

204. Krysko DV, Vanden Berghe T, D'Herde K, Vandenabeele P. Apoptosis and necrosis: Detection, discrimination and phagocytosis. Methods. 2008; 44:205-221. [PubMed: 18314051]

205. Kuo PC, Drachenberg CI, de la Torre A, Bartlett ST, Lim JW, Plotkin JS, Johnson LB. Apoptosis and hepatic allograft reperfusion injury. Clin Transplant. 1998; 12:219-223. [PubMed: 9642513]

206. Kurita S, Mott JL, Cazanave SC, Fingas CD, Guicciardi ME, Bronk SF, Roberts LR, FernandezZapico ME, Gores GJ. Hedgehog inhibition promotes a switch from Type II to Type I cell death receptor signaling in cancer cells. PLoS One. 2011; 6:e18330. [PubMed: 21483830]

207. Kuwana T, Bouchier-Hayes L, Chipuk JE, Bonzon C, Sullivan BA, Green DR, Newmeyer DD. $\mathrm{BH} 3$ domains of $\mathrm{BH} 3$-only proteins differentially regulate Bax-mediated mitochondrial membrane permeabilization both directly and indirectly. Mol Cell. 2005; 17:525-535. [PubMed: 15721256]

208. Kwiecinski M, Elfimova N, Noetel A, Tox U, Steffen HM, Hacker U, Nischt R, Dienes HP, Odenthal M. Expression of platelet-derived growth factor-C and insulin-like growth factor I in hepatic stellate cells is inhibited by miR-29. Lab Invest. 2012

209. LaCasse EC, Mahoney DJ, Cheung HH, Plenchette S, Baird S, Korneluk RG. IAP-targeted therapies for cancer. Oncogene. 2008; 27:6252-6275. [PubMed: 18931692]

210. Lacronique V, Mignon A, Fabre M, Viollet B, Rouquet N, Molina T, Porteu A, Henrion A, Bouscary D, Varlet P, Joulin V, Kahn A. Bcl-2 protects from lethal hepatic apoptosis induced by an anti-Fas antibody in mice. Nat Med. 1996; 2:80-86. [PubMed: 8564847]

211. Lagos-Quintana M, Rauhut R, Yalcin A, Meyer J, Lendeckel W, Tuschl T. Identification of tissue-specific microRNAs from mouse. Curr Biol. 2002; 12:735-739. [PubMed: 12007417]

212. Lajoie P, Moir RD, Willis IM, Snapp EL. Kar2p availability defines distinct forms of endoplasmic reticulum stress in living cells. Mol Biol Cell. 2012; 23:955-964. [PubMed: 22219379]

213. Lau AH, Szabo G, Thomson AW. Antigen-presenting cells under the influence of alcohol. Trends Immunol. 2009; 30:13-22. [PubMed: 19059005]

214. Lee AH, Scapa EF, Cohen DE, Glimcher LH. Regulation of hepatic lipogenesis by the transcription factor XBP1. Science. 2008; 320:1492-1496. [PubMed: 18556558]

215. Lee Y, Jeon K, Lee JT, Kim S, Kim VN. MicroRNA maturation: Stepwise processing and subcellular localization. EMBO J. 2002; 21:4663-4670. [PubMed: 12198168]

216. Lemasters JJ, Nieminen AL, Qian T, Trost LC, Elmore SP, Nishimura Y, Crowe RA, Cascio WE, Bradham CA, Brenner DA, Herman B. The mitochondrial permeability transition in cell death: A common mechanism in necrosis, apoptosis and autophagy. Biochim Biophys acta. 1998; 1366:177-196. [PubMed: 9714796]

217. Lesage G, Glaser S, Ueno Y, Alvaro D, Baiocchi L, Kanno N, Phinizy JL, Francis H, Alpini G. Regression of cholangiocyte proliferation after cessation of ANIT feeding is coupled with increased apoptosis. Am J Physiol Gastrointest Liver Physiol. 2001; 281:G182-G190. [PubMed: 11408271]

218. Letai A, Bassik MC, Walensky LD, Sorcinelli MD, Weiler S, Korsmeyer SJ. Distinct BH3 domains either sensitize or activate mitochondrial apoptosis, serving as prototype cancer therapeutics. Cancer Cell. 2002; 2:183-192. [PubMed: 12242151] 
219. Li F, Huang Q, Chen J, Peng Y, Roop DR, Bedford JS, Li CY. Apoptotic cells activate the "phoenix rising" pathway to promote wound healing and tissue regeneration. Sci Signal. 2010; 3:ra13. [PubMed: 20179271]

220. Li G, Mongillo M, Chin KT, Harding H, Ron D, Marks AR, Tabas I. Role of ERO1-alphamediated stimulation of inositol 1,4,5-triphosphate receptor activity in endoplasmic reticulum stress-induced apoptosis. J Cell Biol. 2009; 186:783-792. [PubMed: 19752026]

221. Li H, Zhu H, Xu CJ, Yuan J. Cleavage of BID by caspase 8 mediates the mitochondrial damage in the Fas pathway of apoptosis. Cell. 1998; 94:491-501. [PubMed: 9727492]

222. Li LY, Luo X, Wang X. Endonuclease G is an apoptotic DNase when released from mitochondria. Nature. 2001; 412:95-99. [PubMed: 11452314]

223. Li P, Nijhawan D, Budihardjo I, Srinivasula SM, Ahmad M, Alnemri ES, Wang X. Cytochrome c and dATP-dependent formation of Apaf-1/caspase-9 complex initiates an apoptotic protease cascade. Cell. 1997; 91:479-489. [PubMed: 9390557]

224. Li Y, Xu X, Liang Y, Liu S, Xiao H, Li F, Cheng H, Fu Z. miR-375 enhances palmitate-induced lipoapoptosis in insulin-secreting NIT-1 cells by repressing myotrophin (V1) protein expression. Int J Clin Exp Pathol. 2010; 3:254-264. [PubMed: 20224724]

225. Lian ZX, Okada T, He XS, Kita H, Liu YJ, Ansari AA, Kikuchi K, Ikehara S, Gershwin ME. Heterogeneity of dendritic cells in the mouse liver: Identification and characterization of four distinct populations. J Immunol. 2003; 170:2323-2330. [PubMed: 12594254]

226. Liedtke C, Bangen JM, Freimuth J, Beraza N, Lambertz D, Cubero FJ, Hatting M, Karlmark KR, Streetz KL, Krombach GA, Tacke F, Gassler N, Riethmacher D, Trautwein C. Loss of caspase-8 protects mice against inflammation-related hepatocarcinogenesis but induces non-apoptotic liver injury. Gastroenterology. 2011; 141:2176-2187. [PubMed: 21878202]

227. Lima RT, Busacca S, Almeida GM, Gaudino G, Fennell DA, Vasconcelos MH. MicroRNA regulation of core apoptosis pathways in cancer. Eur J Cancer. 2011; 47:163-174. [PubMed: 21145728]

228. Lin CJ, Gong HY, Tseng HC, Wang WL, Wu JL. miR-122 targets an anti-apoptotic gene, Bcl-w, in human hepatocellular carcinoma cell lines. Biochem Biophys Res Commun. 2008; 375:315320. [PubMed: 18692484]

229. Lindsten T, Ross AJ, King A, Zong WX, Rathmell JC, Shiels HA, Ul-rich E, Waymire KG, Mahar P, Frauwirth K, Chen Y, Wei M, Eng VM, Adelman DM, Simon MC, Ma A, Golden JA, Evan G, Korsmeyer SJ, MacGregor GR, Thompson CB. The combined functions of proapoptotic Bcl-2 family members bak and bax are essential for normal development of multiple tissues. Mol Cell. 2000; 6:1389-1399. [PubMed: 11163212]

230. Linton SD, Aja T, Armstrong RA, Bai X, Chen LS, Chen N, Ching B, Contreras P, Diaz JL, Fisher CD, Fritz LC, Gladstone P, Groessl T, Gu X, Herrmann J, Hirakawa BP, Hoglen NC, Jahangiri KG, Kalish VJ, Karanewsky DS, Kodandapani L, Krebs J, McQuiston J, Meduna SP, Nalley K, Robinson ED, Sayers RO, Sebring K, Spada AP, Ternansky RJ, Tomaselli KJ, Ullman BR, Valentino KL, Weeks S, Winn D, Wu JC, Yeo P, Zhang CZ. First-in-class pan caspase inhibitor developed for the treatment of liver disease. J Medic Chem. 2005; 48:6779-6782.

231. Liu Y, Binz J, Numerick MJ, Dennis S, Luo G, Desai B, MacKenzie KI, Mansfield TA, Kliewer SA, Goodwin B, Jones SA. Hepatoprotection by the farnesoid X receptor agonist GW4064 in rat models of intra- and extrahepatic cholestasis. J Clin Invest. 2003; 112:1678-1687. [PubMed: 14623915]

232. Liu ZX, Govindarajan S, Kaplowitz N. Innate immune system plays a critical role in determining the progression and severity of acetaminophen hepatotoxicity. Gastroenterology. 2004; 127:1760-1774. [PubMed: 15578514]

233. Llacuna L, Mari M, Lluis JM, Garcia-Ruiz C, Fernandez-Checa JC, Morales A. Reactive oxygen species mediate liver injury through parenchymal nuclear factor-kappaB inactivation in prolonged is-chemia/reperfusion. Am J Pathol. 2009; 174:1776-1785. [PubMed: 19349371]

234. Lotze MT, Zeh HJ, Rubartelli A, Sparvero LJ, Amoscato AA, Washburn NR, Devera ME, Liang $\mathrm{X}$, Tor M, Billiar T. The grateful dead: Damage-associated molecular pattern molecules and reduction/oxidation regulate immunity. Immunol Rev. 2007; 220:60-81. [PubMed: 17979840] 
235. Luo X, Budihardjo I, Zou H, Slaughter C, Wang X. Bid, a Bcl2 interacting protein, mediates cytochrome $\mathrm{c}$ release from mitochondria in response to activation of cell surface death receptors. Cell. 1998; 94:481-490. [PubMed: 9727491]

236. Maillette de Buy Wenniger L, Beuers U. Bile salts and cholestasis. Digest Liver Dis. 2010; 42:409-418.

237. Makishima M, Okamoto AY, Repa JJ, Tu H, Learned RM, Luk A, Hull MV, Lustig KD, Mangelsdorf DJ, Shan B. Identification of a nuclear receptor for bile acids. Science. 1999; 284:1362-1365. [PubMed: 10334992]

238. Malhi H, Gores GJ, Lemasters JJ. Apoptosis and necrosis in the liver: A tale of two deaths? Hepatology. 2006; 43:S31-S44. [PubMed: 16447272]

239. Malhi H, Guicciardi ME, Gores GJ. Hepatocyte death: A clear and present danger. Physiol Rev. 2010; 90:1165-1194. [PubMed: 20664081]

240. Malhi H, Kaufman RJ. Endoplasmic reticulum stress in liver disease. J Hepatol. 2011; 54:795809. [PubMed: 21145844]

241. Marciniak SJ, Yun CY, Oyadomari S, Novoa I, Zhang Y, Jungreis R, Nagata K, Harding HP, Ron D. CHOP induces death by promoting protein synthesis and oxidation in the stressed endoplasmic reticulum. Gene Dev. 2004; 18:3066-3077. [PubMed: 15601821]

242. Martin-Murphy BV, Holt MP, Ju C. The role of damage associated molecular pattern molecules in acetaminophen-induced liver injury in mice. Toxicol Lett. 2010; 192:387-394. [PubMed: 19931603]

243. Martin SJ, Henry CM, Cullen SP. A perspective on mammalian caspases as positive and negative regulators of inflammation. Mol Cell. 2012; 46:387-397. [PubMed: 22633487]

244. Masson MJ, Carpenter LD, Graf ML, Pohl LR. Pathogenic role of natural killer T and natural killer cells in acetaminophen-induced liver injury in mice is dependent on the presence of dimethyl sulfoxide. Hepatology. 2008; 48:889-897. [PubMed: 18712839]

245. Masuoka HC, Guicciardi ME, Gores GJ. Caspase inhibitors for the treatment of hepatitis C. Clin Liver Dis. 2009; 13:467-475. [PubMed: 19628162]

246. McClain CJ, Cohen DA, Dinarello CA, Cannon JG, Shedlofsky SI, Kaplan AM. Serum interleukin-1 (IL-1) activity in alcoholic hepatitis. Life Sci. 1986; 39:1479-1485. [PubMed: 3490610]

247. McCullough KD, Martindale JL, Klotz LO, Aw TY, Holbrook NJ. Gadd153 sensitizes cells to endoplasmic reticulum stress by down-regulating $\mathrm{Bcl} 2$ and perturbing the cellular redox state. Mol Cell Biol. 2001; 21:1249-1259. [PubMed: 11158311]

248. Mehal W, Imaeda A. Cell death and fibrogenesis. Semin Liver Dis. 2010; 30:226-231. [PubMed: 20665375]

249. Menu P, Mayor A, Zhou R, Tardivel A, Ichijo H, Mori K, Tschopp J. ER stress activates the NLRP3 inflammasome via an UPR-independent pathway. Cell Death Dis. 2012; 3:e261. [PubMed: 22278288]

250. Merquiol E, Uzi D, Mueller T, Goldenberg D, Nahmias Y, Xavier RJ, Tirosh B, Shibolet O. HCV causes chronic endoplasmic reticulum stress leading to adaptation and interference with the unfolded protein response. PLoS One. 2011; 6:e24660. [PubMed: 21949742]

251. Miao EA, Rajan JV, Aderem A. Caspase-1-induced pyroptotic cell death. Immunol Rev. 2011; 243:206-214. [PubMed: 21884178]

252. Micheau O, Thome M, Schneider P, Holler N, Tschopp J, Nicholson DW, Briand C, Grutter MG. The long form of FLIP is an activator of caspase- 8 at the Fas death-inducing signaling complex. $\mathrm{J}$ Biol Chem. 2002; 277:45162-45171. [PubMed: 12215447]

253. Mitchell C, Mahrouf-Yorgov M, Mayeuf A, Robin MA, Mansouri A, Fromenty B, Gilgenkrantz $\mathrm{H}$. Overexpression of $\mathrm{Bcl}-2$ in hepatocytes protects against injury but does not attenuate fibrosis in a mouse model of chronic cholestatic liver disease. Lab Invest. 2011; 91:273-282. [PubMed: 20856227]

254. Miyoshi H, Rust C, Roberts PJ, Burgart LJ, Gores GJ. Hepatocyte apoptosis after bile duct ligation in the mouse involves Fas. Gastroenterology. 1999; 117:669-677. [PubMed: 10464144]

255. Mott JL, Kobayashi S, Bronk SF, Gores GJ. mir-29 regulates Mcl-1 protein expression and apoptosis. Oncogene. 2007; 26:6133-6140. [PubMed: 17404574] 
256. Mott JL, Kurita S, Cazanave SC, Bronk SF, Werneburg NW, Fernandez-Zapico ME. Transcriptional suppression of mir-29b-1/mir-29a promoter by c-Myc, hedgehog, and NFkappaB. J Cell Biochem. 2010; 110:1155-1164. [PubMed: 20564213]

257. Mukhopadhyay P, Rajesh M, Horvath B, Batkai S, Park O, Tanchian G, Gao RY, Patel V, Wink DA, Liaudet L, Hasko G, Mechoulam R, Pacher P. Cannabidiol protects against hepatic ischemia/reperfusion injury by attenuating inflammatory signaling and response, oxidative/ nitrative stress, and cell death. Free Radical Bio Med. 2011; 50:1368-1381. [PubMed: 21362471]

258. Nagata S, Hanayama R, Kawane K. Autoimmunity and the clearance of dead cells. Cell. 2010; 140:619-630. [PubMed: 20211132]

259. Naik E, Dixit VM. Modulation of inflammasome activity for the treatment of auto-inflammatory disorders. J Clin Immunol. 2010; 30:485-490. [PubMed: 20358394]

260. Nakagawa T, Shimizu S, Watanabe T, Yamaguchi O, Otsu K, Yamagata H, Inohara H, Kubo T, Tsujimoto Y. Cyclophilin D-dependent mitochondrial permeability transition regulates some necrotic but not apoptotic cell death. Nature. 2005; 434:652-658. [PubMed: 15800626]

261. Nakamoto Y, Kaneko S, Fan H, Momoi T, Tsutsui H, Nakanishi K, Kobayashi K, Suda T. Prevention of hepatocellular carcinoma development associated with chronic hepatitis by anti-fas ligand antibody therapy. J Exp Med. 2002; 196:1105-1111. [PubMed: 12391022]

262. Nakano Y, Kondo T, Matsuo R, Hashimoto I, Kawasaki T, Kohno K, Myronovych A, Tadano S, Hisakura K, Ikeda O, Watanabe M, Murata S, Fukunaga K, Ohkohchi N. Platelet dynamics in the early phase of postischemic liver in vivo. J Surg Res. 2008; 149:192-198. [PubMed: 18468625]

263. Nalapareddy P, Schungel S, Hong JY, Manns MP, Jaeschke H, Vogel A. The BH3-only protein bid does not mediate death-receptor-induced liver injury in obstructive cholestasis. Am J Pathol. 2009; 175:1077-1085. [PubMed: 19661444]

264. Natori S, Higuchi H, Contreras P, Gores GJ. The caspase inhibitor IDN-6556 prevents caspase activation and apoptosis in sinusoidal endothelial cells during liver preservation injury. Liver Transpl. 2003; 9:278-284. [PubMed: 12619025]

265. Natori S, Rust C, Stadheim LM, Srinivasan A, Burgart LJ, Gores GJ. Hepatocyte apoptosis is a pathologic feature of human alcoholic hepatitis. J Hepatol. 2001; 34:248-253. [PubMed: 11281553]

266. Natori S, Selzner M, Valentino KL, Fritz LC, Srinivasan A, Clavien PA, Gores GJ. Apoptosis of sinusoidal endothelial cells occurs during liver preservation injury by a caspase-dependent mechanism. Transplantation. 1999; 68:89-96. [PubMed: 10428274]

267. Nechushtan A, Smith CL, Lamensdorf I, Yoon SH, Youle RJ. Bax and Bak coalesce into novel mitochondria-associated clusters during apoptosis. J Cell Biol. 2001; 153:1265-1276. [PubMed: 11402069]

268. Noack K, Bronk SF, Kato A, Gores GJ. The greater vulnerability of bile duct cells to reoxygenation injury than to anoxia. Implications for the pathogenesis of biliary strictures after liver transplantation. Transplantation. 1993; 56:495-500. [PubMed: 8212138]

269. Noetel A, Kwiecinski M, Elfimova N, Huang J, Odenthal M. microRNA are central players in anti- and profibrotic gene regulation during liver fibrosis. Front Physiol. 2012; 3:49. [PubMed: 22457651]

270. O'Donnell MA, Perez-Jimenez E, Oberst A, Ng A, Massoumi R, Xavier R, Green DR, Ting AT. Caspase 8 inhibits programmed necrosis by processing CYLD. Nat Cell Biol. 2011; 13:14371442. [PubMed: 22037414]

271. Oberhammer F, Bursch W, Tiefenbacher R, Froschl G, Pavelka M, Purchio T, Schulte-Hermann R. Apoptosis is induced by transforming growth factor-beta 1 within 5 hours in regressing liver without significant fragmentation of the DNA. Hepatology. 1993; 18:1238-1246. [PubMed: 8225231]

272. Oberst A, Dillon CP, Weinlich R, McCormick LL, Fitzgerald P, Pop C, Hakem R, Salvesen GS, Green DR. Catalytic activity of the caspase-8-FLIP(L) complex inhibits RIPK3-dependent necrosis. Nature. 2011; 471:363-367. [PubMed: 21368763]

273. Oberst A, Green DR. It cuts both ways: Reconciling the dual roles of caspase 8 in cell death and survival. Nat Rev Mol Cell Biol. 2011; 12:757-763. [PubMed: 22016059] 
274. Ogiku M, Kono H, Hara M, Tsuchiya M, Fujii H. Glycyrrhizin prevents liver injury by inhibition of high-mobility group box 1 production by Kupffer cells after ischemia-reperfusion in rats. $\mathbf{J}$ Pharmacol Exp Ther. 2011; 339:93-98. [PubMed: 21737537]

275. Okano H, Shiraki K, Inoue H, Kawakita T, Yamanaka T, Deguchi M, Sugimoto K, Sakai T, Ohmori S, Fujikawa K, Murata K, Nakano T. Cellular FLICE/caspase-8-inhibitory protein as a principal regulator of cell death and survival in human hepatocellular carcinoma. Lab Invest. 2003; 83:1033-1043. [PubMed: 12861043]

276. Omenetti A, Porrello A, Jung Y, Yang L, Popov Y, Choi SS, Witek RP, Alpini G, Venter J, Vandongen HM, Syn WK, Baroni GS, Benedetti A, Schuppan D, Diehl AM. Hedgehog signaling regulates epithelial-mesenchymal transition during biliary fibrosis in rodents and humans. J Clin Invest. 2008; 118:3331-3342. [PubMed: 18802480]

277. Pellicciari R, Fiorucci S, Camaioni E, Clerici C, Costantino G, Maloney PR, Morelli A, Parks DJ, Willson TM. 6alpha-ethyl-chenodeoxycholic acid (6-ECDCA), a potent and selective FXR agonist endowed with anticholestatic activity. J Med Chem. 2002; 45:3569-3572. [PubMed: 12166927]

278. Pertoft, H.; Smedsrod, B. Cell Separation: Methods and Selected Applications. Vol. 4. New York: Academic Press; 1987. Separation and Characterization of Liver Cells; p. 1-24.

279. Pierce RH, Vail ME, Ralph L, Campbell JS, Fausto N. Bcl-2 expression inhibits liver carcinogenesis and delays the development of proliferating foci. Am J Pathol. 2002; 160:15551560. [PubMed: 12000706]

280. Pockros PJ, Schiff ER, Shiffman ML, McHutchison JG, Gish RG, Afdhal NH, Makhviladze M, Huyghe M, Hecht D, Oltersdorf T, Shapiro DA. Oral IDN-6556, an antiapoptotic caspase inhibitor, may lower aminotransferase activity in patients with chronic hepatitis C. Hepatology. 2007; 46:324-329. [PubMed: 17654603]

281. Protzer U, Maini MK, Knolle PA. Living in the liver: Hepatic infections. Nat Rev Immunol. 2012; 12:201-213. [PubMed: 22362353]

282. Puthalakath H, O'Reilly LA, Gunn P, Lee L, Kelly PN, Huntington ND, Hughes PD, Michalak EM, McKimm-Breschkin J, Motoyama N, Gotoh T, Akira S, Bouillet P, Strasser A. ER stress triggers apoptosis by activating BH3-only protein Bim. Cell. 2007; 129:1337-1349. [PubMed: 17604722]

283. Qiu W, Wang X, Leibowitz B, Yang W, Zhang L, Yu J. PUMA-mediated apoptosis drives chemical hepatocarcinogenesis in mice. Hepatology. 2011; 54:1249-1258. [PubMed: 21725994]

284. Ramachandran A, Lebofsky M, Baines CP, Lemasters JJ, Jaeschke H. Cyclophilin D deficiency protects against acetaminophen-induced oxidant stress and liver injury. Free Radical Res. 2011; 45:156-164. [PubMed: 20942566]

285. Rasola A, Bernardi P. The mitochondrial permeability transition pore and its involvement in cell death and in disease pathogenesis. Apoptosis. 2007; 12:815-833. [PubMed: 17294078]

286. Rathinam VA, Vanaja SK, Fitzgerald KA. Regulation of inflammasome signaling. Nat Immunol. $2012 ; 13: 332$.

287. Ren D, Tu HC, Kim H, Wang GX, Bean GR, Takeuchi O, Jeffers JR, Zambetti GP, Hsieh JJ, Cheng EH. BID, BIM, and PUMA are essential for activation of the BAX- and BAK-dependent cell death program. Science. 2010; 330:1390-1393. [PubMed: 21127253]

288. Repnik U, Stoka V, Turk V, Turk B. Lysosomes and lysosomal cathepsins in cell death. Biochim Biophys Acta. 2012; 1824:22-33. [PubMed: 21914490]

289. Repnik U, Turk B. Lysosomal-mitochondrial cross-talk during cell death. Mitochondrion. 2010; 10:662-669. [PubMed: 20696281]

290. Ricchelli F, Sileikyte J, Bernardi P. Shedding light on the mitochondrial permeability transition. Biochim Biophys Acta. 2011; 1807:482-490. [PubMed: 21377443]

291. Roberg K, Kagedal K, Ollinger K. Microinjection of cathepsin d induces caspase-dependent apoptosis in fibroblasts. Am J Pathol. 2002; 161:89-96. [PubMed: 12107093]

292. Roderburg C, Urban GW, Bettermann K, Vucur M, Zimmermann H, Schmidt S, Janssen J, Koppe C, Knolle P, Castoldi M, Tacke F, Trautwein C, Luedde T. Micro-RNA profiling reveals a role for miR-29 in human and murine liver fibrosis. Hepatology. 2011; 53:209-218. [PubMed: 20890893] 
293. Rodrigues CM, Fan G, Ma X, Kren BT, Steer CJ. A novel role for ursodeoxycholic acid in inhibiting apoptosis by modulating mitochondrial membrane perturbation. J Clin Invest. 1998; 101:2790-2799. [PubMed: 9637713]

294. Rodrigues CM, Ma X, Linehan-Stieers C, Fan G, Kren BT, Steer CJ. Ursodeoxycholic acid prevents cytochrome $\mathrm{c}$ release in apoptosis by inhibiting mitochondrial membrane depolarization and channel formation. Cell Death Differ. 1999; 6:842-854. [PubMed: 10510466]

295. Roma MG, Toledo FD, Boaglio AC, Basiglio CL, Crocenzi FA, Sanchez Pozzi EJ. Ursodeoxycholic acid in cholestasis: Linking action mechanisms to therapeutic applications. Clin Sci. 2011; 121:523-544. [PubMed: 21854363]

296. Roychowdhury S, Chiang DJ, Mandal P, McMullen MR, Liu X, Cohen JI, Pollard J, Feldstein AE, Nagy LE. Inhibition of apoptosis protects mice from ethanol-mediated acceleration of early markers of $\mathrm{CCl}(4)$-induced fibrosis but not steatosis or inflammation. Alcohol Clin Exp Res. 2012; 36:1139-1147. [PubMed: 22273278]

297. Rust C, Karnitz LM, Paya CV, Moscat J, Simari RD, Gores GJ. The bile acid taurochenodeoxycholate activates a phosphatidylinositol 3-kinase-dependent survival signaling cascade. J Biol Chem. 2000; 275:20210-20216. [PubMed: 10770953]

298. Rust C, Wild N, Bernt C, Vennegeerts T, Wimmer R, Beuers U. Bile acid-induced apoptosis in hepatocytes is caspase-6-dependent. J Biol Chem. 2009; 284:2908-2916. [PubMed: 19017654]

299. Saelens X, Festjens N, Vande Walle L, van Gurp M, van Loo G, Vandenabeele P. Toxic proteins released from mitochondria in cell death. Oncogene. 2004; 23:2861-2874. [PubMed: 15077149]

300. Sandgren EP, Palmiter RD, Heckel JL, Daugherty CC, Brinster RL, Degen JL. Complete hepatic regeneration after somatic deletion of an albumin-plasminogen activator transgene. Cell. 1991; 66:245-256. [PubMed: 1713128]

301. Santodomingo-Garzon T, Swain MG. Role of NKT cells in autoimmune liver disease. Autoimmun Rev. 2011; 10:793-800. [PubMed: 21740985]

302. Schattenberg JM, Galle PR, Schuchmann M. Apoptosis in liver disease. Liver Int. 2006; $26: 904$ 911. [PubMed: 16953829]

303. Schattenberg JM, Schuchmann M, Galle PR. Cell death and hepatocarcinogenesis: Dysregulation of apoptosis signaling pathways. J Gastroenterol Hepatol. 2011; 26(Suppl 1):213-219. [PubMed: 21199533]

304. Schoemaker MH, Gommans WM, Conde de la Rosa L, Homan M, Klok P, Trautwein C, van Goor H, Poelstra K, Haisma HJ, Jansen PL, Moshage H. Resistance of rat hepatocytes against bile acid-induced apoptosis in cholestatic liver injury is due to nuclear factor-kappa B activation. J Hepatol. 2003; 39:153-161. [PubMed: 12873810]

305. Schuchmann M, Galle PR. Apoptosis in liver disease. Eur J Gastroen Hepat. 2001; 13:785-790.

306. Schungel S, Buitrago-Molina LE, Nalapareddy P, Lebofsky M, Manns MP, Jaeschke H, Gross A, Vogel A. The strength of the Fas ligand signal determines whether hepatocytes act as type 1 or type 2 cells in murine livers. Hepatology. 2009; 50:1558-1566. [PubMed: 19711425]

307. Segui B, Cuvillier O, Adam-Klages S, Garcia V, Malagarie-Cazenave S, Leveque S, CasparBauguil S, Coudert J, Salvayre R, Kronke M, Levade T. Involvement of FAN in TNF-induced apoptosis. J Clin Invest. 2001; 108:143-151. [PubMed: 11435466]

308. Seki S, Nakashima H, Nakashima M, Kinoshita M. Antitumor immunity produced by the liver Kupffer cells, NK cells, NKT cells, and CD8 CD122 T cells. Clin Dev Immunol. 2011; 2011:868345. [PubMed: 22190974]

309. Sekine S, Ogawa R, Ito R, Hiraoka N, McManus MT, Kanai Y, Hebrok M. Disruption of Dicer1 induces dysregulated fetal gene expression and promotes hepatocarcinogenesis. Gastroenterology. 2009; 136:2304-2315. [PubMed: 19272382]

310. Sekiya Y, Ogawa T, Yoshizato K, Ikeda K, Kawada N. Suppression of hepatic stellate cell activation by microRNA-29b. Biochem Biophys Res Commun. 2011; 412:74-79. [PubMed: 21798245]

311. Selbach M, Schwanhausser B, Thierfelder N, Fang Z, Khanin R, Rajewsky N. Widespread changes in protein synthesis induced by microR-NAs. Nature. 2008; 455:58-63. [PubMed: 18668040] 
312. Selzner M, Rudiger HA, Selzner N, Thomas DW, Sindram D, Clavien PA. Transgenic mice overexpressing human Bcl-2 are resistant to hepatic ischemia and reperfusion. J Hepatol. 2002; 36:218-225. [PubMed: 11830333]

313. Selzner M, Rudiger HA, Sindram D, Madden J, Clavien PA. Mechanisms of ischemic injury are different in the steatotic and normal rat liver. Hepatology. 2000; 32:1280-1288. [PubMed: 11093735]

314. Shi FD, Ljunggren HG, La Cava A, Van Kaer L. Organ-specific features of natural killer cells. Nat Rev Immunol. 2011; 11:658-671. [PubMed: 21941294]

315. Shimada T. Xenobiotic-metabolizing enzymes involved in activation and detoxification of carcinogenic polycyclic aromatic hydrocarbons. Drug Metab Pharmacok. 2006; 21:257-276.

316. Shimbo K, Hsu GW, Nguyen H, Mahrus S, Trinidad JC, Burlingame AL, Wells JA. Quantitative profiling of caspase-cleaved substrates reveals different drug-induced and cell-type patterns in apoptosis. Proc Natl Acad Sci U S A. 2012; 109:12432-12437. [PubMed: 22802652]

317. Shito M, Wakabayashi G, Ueda M, Shimazu M, Shirasugi N, Endo M, Mukai M, Kitajima M. Interleukin 1 receptor blockade reduces tumor necrosis factor production, tissue injury, and mortality after hepatic ischemia-reperfusion in the rat. Transplantation. 1997; 63:143-148. [PubMed: 9000676]

318. Sieghart W, Losert D, Strommer S, Cejka D, Schmid K, Rasoul-Rockenschaub S, Bodingbauer M, Crevenna R, Monia BP, Peck-Radosavljevic M, Wacheck V. Mcl-1 overexpression in hepatocellular carcinoma: A potential target for antisense therapy. J Hepatol. 2006; 44:151-157. [PubMed: 16289418]

319. Silva MT. Secondary necrosis: The natural outcome of the complete apoptotic program. FEBS Lett. 2010; 584:4491-4499. [PubMed: 20974143]

320. Sinal CJ, Tohkin M, Miyata M, Ward JM, Lambert G, Gonzalez FJ. Targeted disruption of the nuclear receptor FXR/BAR impairs bile acid and lipid homeostasis. Cell. 2000; 102:731-744. [PubMed: 11030617]

321. Sindram D, Porte RJ, Hoffman MR, Bentley RC, Clavien PA. Platelets induce sinusoidal endothelial cell apoptosis upon reperfusion of the cold ischemic rat liver. Gastroenterology. 2000; 118:183-191. [PubMed: 10611167]

322. Sodeman T, Bronk SF, Roberts PJ, Miyoshi H, Gores GJ. Bile salts mediate hepatocyte apoptosis by increasing cell surface trafficking of Fas. Am J Physiol Gastrointest Liver Physiol. 2000; 278:G992-G999. [PubMed: 10859230]

323. Starkey Lewis PJ, Dear J, Platt V, Simpson KJ, Craig DG, Antoine DJ, French NS, Dhaun N, Webb DJ, Costello EM, Neoptolemos JP, Moggs J, Goldring CE, Park BK. Circulating microRNAs as potential markers of human drug-induced liver injury. Hepatology. 2011; 54:1767-1776. [PubMed: 22045675]

324. Steele R, Mott JL, Ray RB. MBP-1 upregulates miR-29b that represses Mcl-1, collagens, and matrix-metalloproteinase-2 in prostate cancer cells. Genes Cancer. 2010; 1:381-387. [PubMed: 20657750]

325. Stoka V, Turk B, Schendel SL, Kim TH, Cirman T, Snipas SJ, Ellerby LM, Bredesen D, Freeze H, Abrahamson M, Bromme D, Krajewski S, Reed JC, Yin XM, Turk V, Salvesen GS. Lysosomal protease pathways to apoptosis. Cleavage of bid, not pro-caspases, is the most likely route. J Biol Chem. 2001; 276:3149-3157. [PubMed: 11073962]

326. Strautnieks SS, Bull LN, Knisely AS, Kocoshis SA, Dahl N, Arnell H, Sokal E, Dahan K, Childs S, Ling V, Tanner MS, Kagalwalla AF, Nemeth A, Pawlowska J, Baker A, Mieli-Vergani G, Freimer NB, Gardiner RM, Thompson RJ. A gene encoding a liver-specific ABC transporter is mutated in progressive familial intrahepatic cholestasis. Nat Genet. 1998; 20:233-238. [PubMed: 9806540]

327. Strautnieks SS, Byrne JA, Pawlikowska L, Cebecauerova D, Rayner A, Dutton L, Meier Y, Antoniou A, Stieger B, Arnell H, Ozcay F, Al-Hussaini HF, Bassas AF, Verkade HJ, Fischler B, Nemeth A, Kotalova R, Shneider BL, Cielecka-Kuszyk J, McClean P, Whitington PF, Sokal E, Jirsa M, Wali SH, Jankowska I, Pawlowska J, Mieli-Vergani G, Knisely AS, Bull LN, Thompson RJ. Severe bile salt export pump deficiency: 82 different ABCB11 mutations in 109 families. Gastroenterology. 2008; 134:1203-1214. [PubMed: 18395098] 
328. Sun L, Wang H, Wang Z, He S, Chen S, Liao D, Wang L, Yan J, Liu W, Lei X, Wang X. Mixed lineage kinase domain-like protein mediates necrosis signaling downstream of RIP3 kinase. Cell. 2012; 148:213-227. [PubMed: 22265413]

329. Sun X, Lee J, Navas T, Baldwin DT, Stewart TA, Dixit VM. RIP3, a novel apoptosis-inducing kinase. J Biol Chem. 1999; 274:16871-16875. [PubMed: 10358032]

330. Szabo G, Mandrekar P. A recent perspective on alcohol, immunity, and host defense. Alcohol Clin Exp Res. 2009; 33:220-232. [PubMed: 19053973]

331. Tabas I, Ron D. Integrating the mechanisms of apoptosis induced by endoplasmic reticulum stress. Nat Cell Biol. 2011; 13:184-190. [PubMed: 21364565]

332. Tacke F, Luedde T, Trautwein C. Inflammatory pathways in liver homeostasis and liver injury. Clin Rev Allerg Immu. 2009; 36:4-12.

333. Takeda K, Kojima Y, Ikejima K, Harada K, Yamashina S, Okumura K, Aoyama T, Frese S, Ikeda H, Haynes NM, Cretney E, Yagita H, Sueyoshi N, Sato N, Nakanuma Y, Smyth MJ. Death receptor 5 mediated-apoptosis contributes to cholestatic liver disease. Proc Natl Acad Sci U S A. 2008; 105:10895-10900. [PubMed: 18667695]

334. Takehara T, Liu X, Fujimoto J, Friedman SL, Takahashi H. Expression and role of Bcl-xL in human hepatocellular carcinomas. Hepatology. 2001; 34:55-61. [PubMed: 11431734]

335. Takehara T, Takahashi H. Suppression of Bcl-xL deamidation in human hepatocellular carcinomas. Cancer Res. 2003; 63:3054-3057. [PubMed: 12810626]

336. Takehara T, Tatsumi T, Suzuki T, Rucker EB III, Hennighausen L, Jinushi M, Miyagi T, Kanazawa Y, Hayashi N. Hepatocyte-specific disruption of Bcl-xL leads to continuous hepatocyte apoptosis and liver fibrotic responses. Gastroenterology. 2004; 127:1189-1197. [PubMed: 15480996]

337. Takeuchi O, Akira S. Pattern recognition receptors and inflammation. Cell. 2010; 140:805-820. [PubMed: 20303872]

338. Takikawa Y, Miyoshi H, Rust C, Roberts P, Siegel R, Mandal PK, Millikan RE, Gores GJ. The bile acid-activated phosphatidylinositol 3-kinase pathway inhibits Fas apoptosis upstream of bid in rodent hepatocytes. Gastroenterology. 2001; 120:1810-1817. [PubMed: 11375961]

339. Tamimi TI, Elgouhari HM, Alkhouri N, Yerian LM, Berk MP, Lopez R, Schauer PR, Zein NN, Feldstein AE. An apoptosis panel for nonalcoholic steatohepatitis diagnosis. J Hepatol. 2011; 54:1224-1229. [PubMed: 21145805]

340. Taniai H, Hines IN, Bharwani S, Maloney RE, Nimura Y, Gao B, Flores SC, McCord JM, Grisham MB, Aw TY. Susceptibility of murine periportal hepatocytes to hypoxia-reoxygenation: Role for NO and Kupffer cell-derived oxidants. Hepatology. 2004; 39:1544-1552. [PubMed: 15185295]

341. Taniai M, Grambihler A, Higuchi H, Werneburg N, Bronk SF, Farrugia DJ, Kaufmann SH, Gores GJ. Mcl-1 mediates tumor necrosis factor-related apoptosis-inducing ligand resistance in human cholangiocarcinoma cells. Cancer Res. 2004; 64:3517-3524. [PubMed: 15150106]

342. Taylor RC, Cullen SP, Martin SJ. Apoptosis: Controlled demolition at the cellular level. Nat Rev Mol Cell Biol. 2008; 9:231-241. [PubMed: 18073771]

343. Tenev T, Bianchi K, Darding M, Broemer M, Langlais C, Wallberg F, Zachariou A, Lopez J, MacFarlane M, Cain K, Meier P. The Ripoptosome, a signaling platform that assembles in response to genotoxic stress and loss of IAPs. Mol Cell. 2011; 43:432-448. [PubMed: 21737329]

344. Tiegs G, Lohse AW. Immune tolerance: What is unique about the liver. J Autoimmun. 2010; 34:1-6. [PubMed: 19717280]

345. Timmins JM, Ozcan L, Seimon TA, Li G, Malagelada C, Backs J, Backs T, Bassel-Duby R, Olson EN, Anderson ME, Tabas I. Calcium/calmodulin-dependent protein kinase II links ER stress with Fas and mitochondrial apoptosis pathways. J Clin Invest. 2009; 119:2925-2941. [PubMed: 19741297]

346. Torchia EC, Stolz A, Agellon LB. Differential modulation of cellular death and survival pathways by conjugated bile acids. BMC Biochem. 2001; 2:11. [PubMed: 11707155]

347. Trauner M, Boyer JL. Bile salt transporters: Molecular characterization, function, and regulation. Physiol Rev. 2003; 83:633-671. [PubMed: 12663868] 
348. Tryndyak VP, Latendresse JR, Montgomery B, Ross SA, Beland FA, Rusyn I, Pogribny IP. Plasma microRNAs are sensitive indicators of inter-strain differences in the severity of liver injury induced in mice by a choline- and folate-deficient diet. Toxicol Appl Pharmacol. 2012; 262:52-9. [PubMed: 22561871]

349. Tsung A, Hoffman RA, Izuishi K, Critchlow ND, Nakao A, Chan MH, Lotze MT, Geller DA, Billiar TR. Hepatic ischemia/reperfusion injury involves functional TLR4 signaling in nonparenchymal cells. J Immunol. 2005; 175:7661-7668. [PubMed: 16301676]

350. Tzung SP, Fausto N, Hockenbery DM. Expression of Bcl-2 family during liver regeneration and identification of Bcl-x as a delayed early response gene. Am J Pathol. 1997; 150:1985-1995. [PubMed: 9176392]

351. Uchimoto T, Nohara H, Kamehara R, Iwamura M, Watanabe N, Kobayashi Y. Mechanism of apoptosis induced by a lysosomotropic agent, L-Leucyl-L-Leucine methyl ester. Apoptosis. 1999; 4:357-362. [PubMed: 14634338]

352. Urano F, Wang X, Bertolotti A, Zhang Y, Chung P, Harding HP, Ron D. Coupling of stress in the ER to activation of JNK protein kinases by transmembrane protein kinase IRE1. Science. 2000; 287:664-666. [PubMed: 10650002]

353. Valles SL, Blanco AM, Azorin I, Guasch R, Pascual M, Gomez-Lechon MJ, Renau-Piqueras J, Guerri C. Chronic ethanol consumption enhances interleukin-1-mediated signal transduction in rat liver and in cultured hepatocytes. Alcohol Clin Exp Res. 2003; 27:1979-1986. [PubMed: 14691386]

354. Van Vre EA, Ait-Oufella H, Tedgui A, Mallat Z. Apoptotic cell death and efferocytosis in atherosclerosis. Arterioscler Thromb Vasc Biol. 2012; 32:887-893. [PubMed: 22328779]

355. Vandanmagsar B, Youm YH, Ravussin A, Galgani JE, Stadler K, Mynatt RL, Ravussin E, Stephens JM, Dixit VD. The NLRP3 inflammasome instigates obesity-induced inflammation and insulin resistance. Nat Med. 2011; 17:179-188. [PubMed: 21217695]

356. Vanden Berghe T, Vanlangenakker N, Parthoens E, Deckers W, Devos M, Festjens N, Guerin CJ, Brunk UT, Declercq W, Vandenabeele P. Necroptosis, necrosis and secondary necrosis converge on similar cellular disintegration features. Cell Death Differ. 2010; 17:922-930. [PubMed: 20010783]

357. Vandenabeele P, Galluzzi L, Vanden Berghe T, Kroemer G. Molecular mechanisms of necroptosis: An ordered cellular explosion. Nat Rev Mol Cell Biol. 2010; 11:700-714. [PubMed: 20823910]

358. Varfolomeev E, Goncharov T, Fedorova AV, Dynek JN, Zobel K, Deshayes K, Fairbrother WJ, Vucic D. c-IAP1 and c-IAP2 are critical mediators of tumor necrosis factor alpha (TNFalpha)induced NF-kappaB activation. J Biol Chem. 2008; 283:24295-24299. [PubMed: 18621737]

359. Varfolomeev EE, Schuchmann M, Luria V, Chiannilkulchai N, Beckmann JS, Mett IL, Rebrikov D, Brodianski VM, Kemper OC, Kollet O, Lapidot T, Soffer D, Sobe T, Avraham KB, Goncharov T, Holtmann H, Lonai P, Wallach D. Targeted disruption of the mouse Caspase 8 gene ablates cell death induction by the TNF receptors, Fas/Apo1, and DR3 and is lethal prenatally. Immunity. 1998; 9:267-276. [PubMed: 9729047]

360. Verma S, Kaplowitz N. Diagnosis, management and prevention of drug-induced liver injury. Gut. 2009; 58:1555-1564. [PubMed: 19834119]

361. Vick B, Weber A, Urbanik T, Maass T, Teufel A, Krammer PH, Opferman JT, Schuchmann M, Galle PR, Schulze-Bergkamen H. Knockout of myeloid cell leukemia-1 induces liver damage and increases apop-tosis susceptibility of murine hepatocytes. Hepatology. 2009; 49:627-636. [PubMed: 19127517]

362. Volinia S, Calin GA, Liu CG, Ambs S, Cimmino A, Petrocca F, Visone R, Iorio M, Roldo C, Ferracin M, Prueitt RL, Yanaihara N, Lanza G, Scarpa A, Vecchione A, Negrini M, Harris CC, Croce CM. AmicroRNA expression signature of human solid tumors defines cancer gene targets. Proc Natl Acad Sci U S A. 2006; 103:2257-2261. [PubMed: 16461460]

363. von Oppen N, Schurich A, Hegenbarth S, Stabenow D, Tolba R, Weiskirchen R, Geerts A, Kolanus W, Knolle P, Diehl L. Systemic antigen cross-presented by liver sinusoidal endothelial cells induces liver-specific CD8 T-cell retention and tolerization. Hepatology. 2009; 49:16641672. [PubMed: 19205034] 
364. Vucic D. Targeting IAP (inhibitor of apoptosis) proteins for therapeutic intervention in tumors. Curr Cancer Drug Targets. 2008; 8:110-117. [PubMed: 18336193]

365. Walensky LD. From mitochondrial biology to magic bullet: Navitoclax disarms BCL-2 in chronic lymphocytic leukemia. J Clin Oncol. 2012; 30:554-557. [PubMed: 22184389]

366. Wallace DC, Fan W. The pathophysiology of mitochondrial disease as modeled in the mouse. Gene Dev. 2009; 23:1714-1736. [PubMed: 19651984]

367. Walter D, Schmich K, Vogel S, Pick R, Kaufmann T, Hochmuth FC, Haber A, Neubert K, McNelly S, von Weizsacker F, Merfort I, Maurer U, Strasser A, Borner C. Switch from type II to I Fas/CD95 death signaling on in vitro culturing of primary hepatocytes. Hepatology. 2008; 48:1942-1953. [PubMed: 19003879]

368. Wang D, Wei Y, Pagliassotti MJ. Saturated fatty acids promote endoplasmic reticulum stress and liver injury in rats with hepatic steatosis. Endocrinology. 2006; 147:943-951. [PubMed: 16269465]

369. Wang Y, Lu Y, Toh ST, Sung WK, Tan P, Chow P, Chung AY, Jooi LL, Lee CG. Lethal-7 is down-regulated by the hepatitis $\mathrm{B}$ virus $\mathrm{x}$ protein and targets signal transducer and activator of transcription 3. J Hepatol. 2010; 53:57-66. [PubMed: 20447714]

370. Wang Y, Vera L, Fischer WH, Montminy M. The CREB coactivator CRTC2 links hepatic ER stress and fasting gluconeogenesis. Nature. 2009; 460:534-537. [PubMed: 19543265]

371. Weber A, Boger R, Vick B, Urbanik T, Haybaeck J, Zoller S, Teufel A, Krammer PH, Opferman JT, Galle PR, Schuchmann M, Heiken-walder M, Schulze-Bergkamen H. Hepatocyte-specific deletion of the antiapoptotic protein myeloid cell leukemia-1 triggers proliferation and hepatocarcinogenesis in mice. Hepatology. 2010; 51:1226-1236. [PubMed: 20099303]

372. Wei G, Margolin AA, Haery L, Brown E, Cucolo L, Julian B, Shehata S, Kung AL, Beroukhim $\mathrm{R}$, Golub TR. Chemical genomics identifies small-molecule MCL1 repressors and BCL-xL as a predictor of MCL1 dependency. Cancer Cell. 2012; 21:547-562. [PubMed: 22516262]

373. Wei MC, Zong WX, Cheng EH, Lindsten T, Panoutsakopoulou V, Ross AJ, Roth KA, MacGregor GR, Thompson CB, Korsmeyer SJ. Proapoptotic BAX and BAK: A requisite gateway to mitochondrial dysfunction and death. Science. 2001; 292:727-730. [PubMed: 11326099]

374. Wen H, Gris D, Lei Y, Jha S, Zhang L, Huang MT, Brickey WJ, Ting JP. Fatty acid-induced NLRP3-ASC inflammasome activation interferes with insulin signaling. Nat Immunol. 2011; 12:408-415. [PubMed: 21478880]

375. Weng SY, Yang CY, Li CC, Sun TP, Tung SY, Yen JJ, Tsai TF, Chen CM, Chen SH, Hsiao M, Huang PH, Yang-Yen HF. Synergism between p53 and Mcl-1 in protecting from hepatic injury, fibrosis and cancer. J Hepatol. 2011; 54:685-694. [PubMed: 21146511]

376. Werneburg N, Guicciardi ME, Yin XM, Gores GJ. TNF-alpha-mediated lysosomal permeabilization is FAN and caspase 8/Bid dependent. Am J Physiol Gastrointest Liver Physiol. 2004; 287:G436-G443. [PubMed: 15075251]

377. Werneburg NW, Bronk SF, Guicciardi ME, Thomas L, Dikeakos JD, Thomas G, Gores GJ. Tumor necrosis factor-related apoptosis inducing ligand (TRAIL) induced lysosomal translocation of proapoptotic effectors is mediated by phosphofurin acidic cluster sorting protein-2 (PACS-2). J Biol Chem. 2012; 287:24427-24437. [PubMed: 22645134]

378. Werneburg NW, Guicciardi ME, Bronk SF, Kaufmann SH, Gores GJ. Tumor necrosis factorrelated apoptosis-inducing ligand activates a lysosomal pathway of apoptosis that is regulated by Bcl-2 proteins. J Biol Chem. 2007; 282:28960-28970. [PubMed: 17686764]

379. Williams CD, Antoine DJ, Shaw PJ, Benson C, Farhood A, Williams DP, Kanneganti TD, Park BK, Jaeschke H. Role of the Nalp3 inflammasome in acetaminophen-induced sterile inflammation and liver injury. Toxicol Appl Pharmacol. 2011; 252:289-297. [PubMed: 21396389]

380. Williams CD, Farhood A, Jaeschke H. Role of caspase-1 and interleukin-1beta in acetaminopheninduced hepatic inflammation and liver injury. Toxicol Appl Pharmacol. 2010; 247:169-178. [PubMed: 20637792]

381. Willis SN, Fletcher JI, Kaufmann T, van Delft MF, Chen L, Czabotar PE, Ierino H, Lee EF, Fairlie WD, Bouillet P, Strasser A, Kluck RM, Adams JM, Huang DC. Apoptosis initiated when 
BH3 ligands engage multiple Bcl-2 homologs, not Bax or Bak. Science. 2007; 315:856-859. [PubMed: 17289999]

382. Winau F, Hegasy G, Weiskirchen R, Weber S, Cassan C, Sieling PA, Modlin RL, Liblau RS, Gressner AM, Kaufmann SH. Ito cells are liver-resident antigen-presenting cells for activating T cell responses. Immunity. 2007; 26:117-129. [PubMed: 17239632]

383. Witek RP, Stone WC, Karaca FG, Syn WK, Pereira TA, Agboola KM, Omenetti A, Jung Y, Teaberry V, Choi SS, Guy CD, Pollard J, Charlton P, Diehl AM. Pan-caspase inhibitor VX-166 reduces fibrosis in an animal model of nonalcoholic steatohepatitis. Hepatology. 2009; 50:14211430. [PubMed: 19676126]

384. Wong LT, Whitehouse LW, Solomonraj G, Paul CJ. Effect of a concomitant single dose of ethanol on the hepatotoxicity and metabolism of acetaminophen in mice. Toxicology. 1980; 17:297-309. [PubMed: 7210015]

385. Wyllie AH, Kerr JF, Currie AR. Cell death: The significance of apoptosis. Int Rev Cytol. 1980; 68:251-306. [PubMed: 7014501]

386. Xia Z, Dickens M, Raingeaud J, Davis RJ, Greenberg ME. Opposing effects of ERK and JNKp38 MAP kinases on apoptosis. Science. 1995; 270:1326-1331. [PubMed: 7481820]

387. Xiong Y, Fang JH, Yun JP, Yang J, Zhang Y, Jia WH, Zhuang SM. Effects of microRNA-29 on apoptosis, tumorigenicity, and prognosis of hepatocellular carcinoma. Hepatology. 2010; 51:836-845. [PubMed: 20041405]

388. Xu J, Zhu X, Wu L, Yang R, Yang Z, Wang Q, Wu F. MicroRNA-122 suppresses cell proliferation and induces cell apoptosis in hepatocellular carcinoma by directly targeting Wnt/ beta-catenin pathway. Liver Int. 2012; 32:752-760. [PubMed: 22276989]

389. Yamaguchi H, Wang HG. CHOP is involved in endoplasmic reticu-lum stress-induced apoptosis by enhancing DR5 expression in human carcinoma cells. J Biol Chem. 2004; 279:45495-45502. [PubMed: 15322075]

390. Yeh WC, Itie A, Elia AJ, Ng M, Shu HB, Wakeham A, Mirtsos C, Suzuki N, Bonnard M, Goeddel DV, Mak TW. Requirement for Casper (c-FLIP) in regulation of death receptor-induced apoptosis and embryonic development. Immunity. 2000; 12:633-642. [PubMed: 10894163]

391. Yerushalmi B, Dahl R, Devereaux MW, Gumpricht E, Sokol RJ. Bile acid-induced rat hepatocyte apoptosis is inhibited by antioxidants and blockers of the mitochondrial permeability transition. Hepatology. 2001; 33:616-626. [PubMed: 11230742]

392. Yin XM. Bid, a critical mediator for apoptosis induced by the activation of Fas/TNF-R1 death receptors in hepatocytes. J Mol Med (Berl). 2000; 78:203-211. [PubMed: 10933582]

393. Yin XM, Ding WX. Death receptor activation-induced hepatocyte apoptosis and liver injury. Curr Mol Med. 2003; 3:491-508. [PubMed: 14527081]

394. Yin XM, Wang K, Gross A, Zhao Y, Zinkel S, Klocke B, Roth KA, Korsmeyer SJ. Bid-deficient mice are resistant to Fas-induced hepato-cellular apoptosis. Nature. 1999; 400:886-891. [PubMed: 10476969]

395. Yoneyama M, Kikuchi M, Natsukawa T, Shinobu N, Imaizumi T, Miyagishi M, Taira K, Akira S, Fujita T. The RNA helicase RIG-I has an essential function in double-stranded RNA-induced innate antiviral responses. Nat Immunol. 2004; 5:730-737. [PubMed: 15208624]

396. Yoon JH, Gores GJ. Death receptor-mediated apoptosis and the liver. 11ll J Hepatol. 2002; 37:400-410.

397. Youle RJ, Strasser A. The BCL-2 protein family: Opposing activities that mediate cell death. Nat Rev Mol Cell Biol. 2008; 9:47-59. [PubMed: 18097445]

398. Yu C, Bruzek LM, Meng XW, Gores GJ, Carter CA, Kaufmann SH, Adjei AA. The role of Mcl-1 downregulation in the proapoptotic activity of the multikinase inhibitor BAY 43-9006. Oncogene. 2005; 24:6861-6869. [PubMed: 16007148]

399. Zajicek G, Oren R, Weinreb M Jr. The streaming liver. Liver. 1985; 5:293-300. [PubMed: 4088003]

400. Zender L, Hutker S, Liedtke C, Tillmann HL, Zender S, Mundt B, Waltemathe M, Gosling T, Flemming P, Malek NP, Trautwein C, Manns MP, Kuhnel F, Kubicka S. Caspase 8 small interfering RNA prevents acute liver failure in mice. Proc Natl Acad Sci U S A. 2003; 100:77977802. [PubMed: 12810955] 
401. Zhang H, Cook J, Nickel J, Yu R, Stecker K, Myers K, Dean NM. Reduction of liver Fas expression by an antisense oligonucleotide protects mice from fulminant hepatitis. Nat Biotechnol. 2000; 18:862-867. [PubMed: 10932156]

402. Zhang N, Hopkins K, He YW. c-FLIP protects mature T lymphocytes from TCR-mediated killing. J Immunol. 2008; 181:5368-5373. [PubMed: 18832693]

403. Zhang Y, Jia Y, Zheng R, Guo Y, Wang Y, Guo H, Fei M, Sun S. Plasma microRNA-122 as a biomarker for viral-, alcohol, and chemical-related hepatic diseases. Clin Chem. 2010; 56:18301838. [PubMed: 20930130]

404. Zhang Y, Wu L, Wang Y, Zhang M, Li L, Zhu D, Li X, Gu H, Zhang CY, Zen K. Protective Role of Estrogen-induced miRNA-29 Expression in Carbon Tetrachloride-induced Mouse Liver Injury. J Biol Chem. 2012; 287:14851-14862. [PubMed: 22393047]

405. Zhu P, Duan L, Chen J, Xiong A, Xu Q, Zhang H, Zheng F, Tan Z, Gong F, Fang M. Gene silencing of NALP3 protects against liver ischemia-reperfusion injury in mice. Hum Gene Ther. 2011; 22:853-864. [PubMed: 21128730]

406. Zinszner H, Kuroda M, Wang X, Batchvarova N, Lightfoot RT, Remotti H, Stevens JL, Ron D. $\mathrm{CHOP}$ is implicated in programmed cell death in response to impaired function of the endoplasmic reticulum. Gene Dev. 1998; 12:982-995. [PubMed: 9531536] 


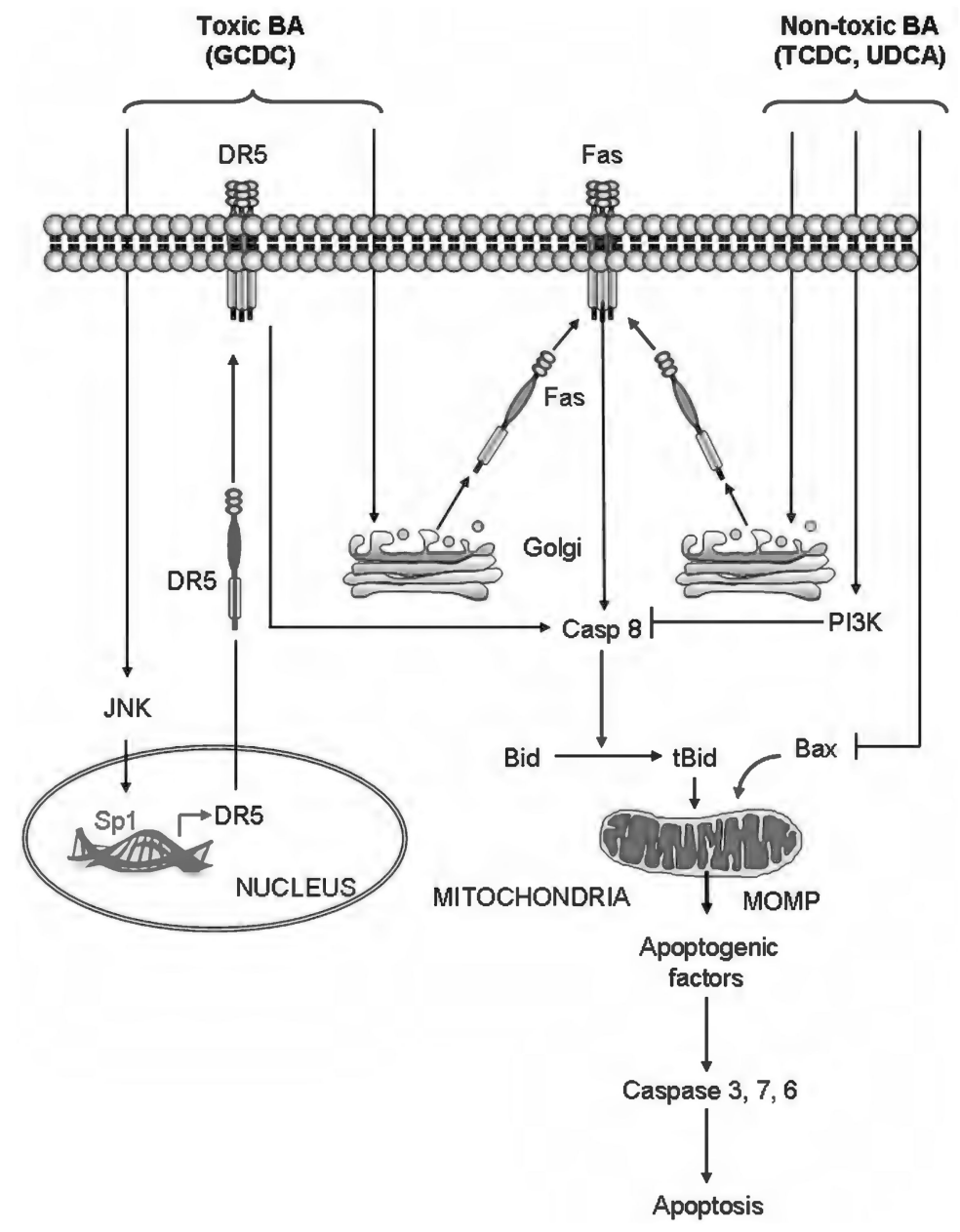

Figure 1.

Bile acid (BA)-induced apoptotic and prosurvival signaling. Internalized toxic (more hydrophobic) bile acids, such as glycine-conjugated form of chenodeoxycholic acid (GCDC), trigger death-receptor-mediated apoptosis. BA stimulate microtubule-dependent trafficking of Fas from the Golgi compartment to the plasma membrane, increasing Fas density on the cell surface and promoting spontaneous Fas oligomerization independent of FasL. This results in activation of caspase 8, which, in turn, cleaves Bid, whose truncated form translocates to mitochondria and cooperates with Bax to induce mitochondrial outer membrane permeabilization (MOMP). Following MOMP, several apoptogenic factors, such as cytochrome $c$, apoptosis-inducing factor and second mitochondrial activator of caspases, are released into the cytosol, which ultimately promote the activation of effector caspases-3, 6 , and 7, and cell death. Moreover, BA activate c-jun N-terminal kinase, resulting in activation of the transcription factor Sp1 (specificity protein 1), which, in turn, upregulates death receptor 5 sensitizing the hepatocytes also to TRAIL-induced apoptosis. Nontoxic BA, such as tauro-conjugate of chenodeoxycholic acid and ursodeoxycholic acid, can also trigger plasma membrane trafficking and activation of Fas. However, the simultaneous activation of cytoprotective pathways which prevent activation of key players such as caspase 8 , Bid, or Bax, blocks the apoptotic cascade and inhibits cell death. 


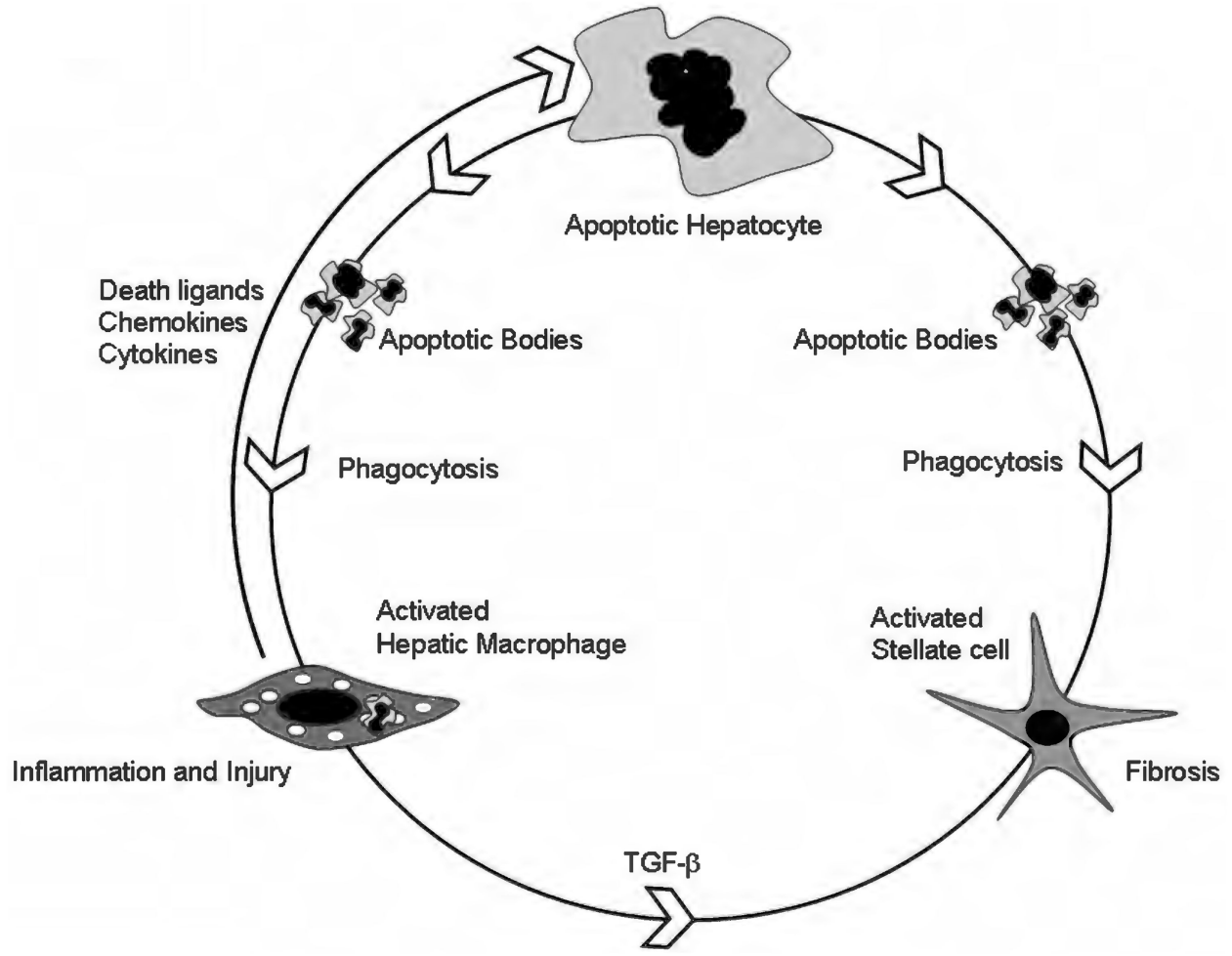

Figure 2.

Apoptosis-inflammation-fibrosis in the liver. This cartoon depicts the circular relationship between apoptosis, inflammation, and fibrosis in the liver. Hepatocyte apoptosis is the central event in the model shown. In the setting of an apoptotic stimulus, for example, toxic bile salts or palmitic acid, a vulnerable hepatocyte undergoes cell death. Apoptotic bodies are formed. These can be engulfed both by hepatic macrophages, also known as Kupffer cells and hepatic stellate cells $(54,57)$. Macrophages, upon activation, in turn release death ligands, such as Fas ligand and TRAIL, both of which can induce hepatocyte apoptosis. Inflammatory cytokines such as TNF- $\alpha$, IL-1 $\beta$, and IL- 6 are also released by activated macrophages (54). These result in liver inflammation and injury. Engulfment of apoptotic bodies in a permissive milieu (inflamed liver with increased fibrogenic signals, such as Transforming growth factor (TGF)- $\beta$ ) results in activation of hepatic stellate cells to myofibroblasts (57). These cells remodel the extracellular matrix resulting in fibrosis and cirrhosis. 


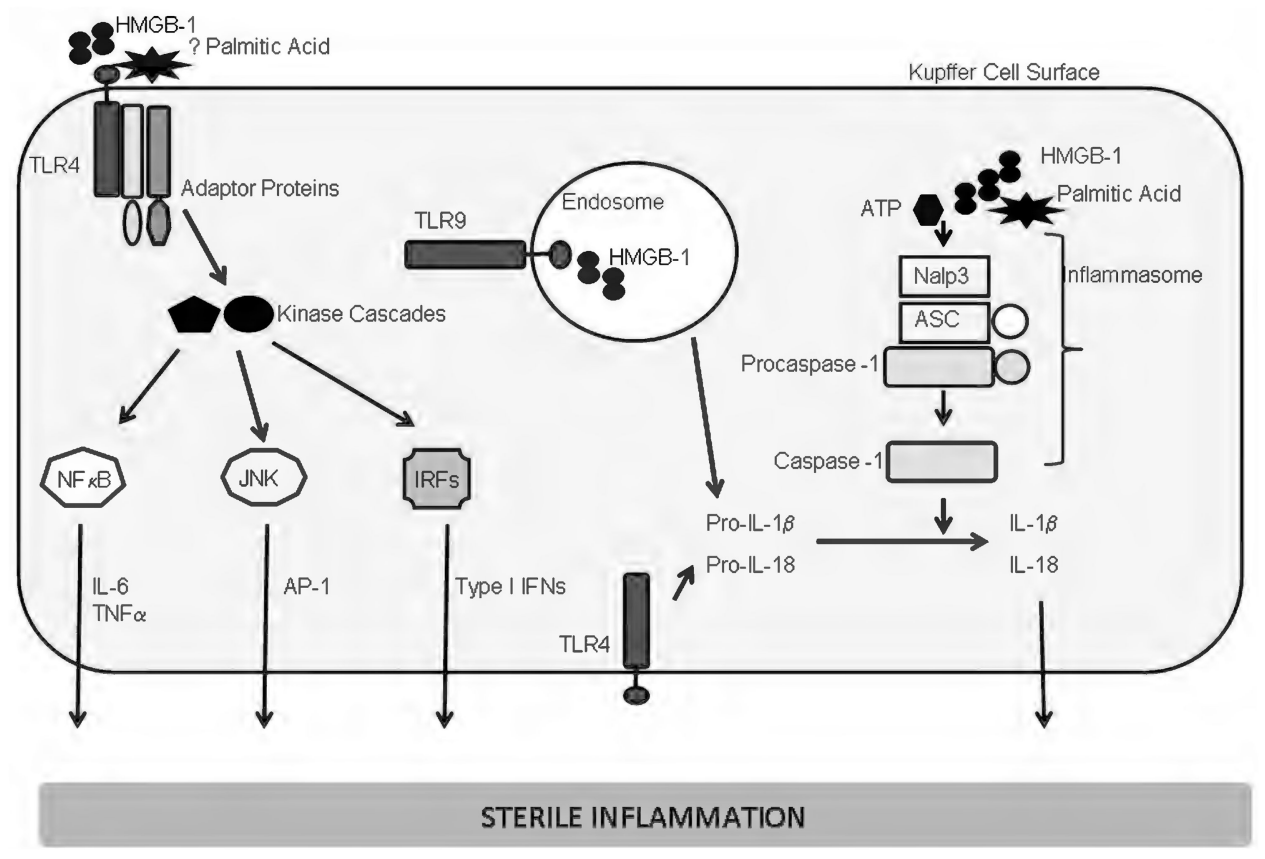

Figure 3.

Sterile inflammation in liver diseases. A model is presented for sterile inflammation in liver diseases. Palmitic acid, a toxic free fatty acid, which can activate the NLRP3 inflammasome and high mobility group box 1 (HMGB-1), a nuclear protein released from dead cells, are shown as activating damage associated molecular patterns (DAMPs). Activation of cel surface toll like receptors (TLRs)-1, 2, 4, 6, 5, or endosomal TLRs $(7,9)$ leads to recruitment of adaptor proteins, activation of kinase cascades that result in activation of nuclear factor $\kappa \mathrm{B}$, c-jun $\mathrm{N}$-terminal kinase, and interferon (IFN) regulatory factors. These result in transcriptional activation of several proinflammatory mediators including interleukin (IL)-6, TNF-a and Type IFNs. The inflammasome can also be activated by many endogenous DAMPs. The mechanism for this activation is not fully elucidated. Shown here is the NLRP3 (nucleotide oligomerization domain [NOD]-like receptor, pyrin domain containing 3) inflammasome. The NLRP3 gene product is the intracellular protein, Nalp3 (NACHT, LRR, and pyrin domain-containing 3). Nalp3, upon activation, recruits ASC (apoptosis-associated speck-like protein containing a CARD, also known as PYCARD), and procaspase-1, leading to the activation of caspase-1. Caspase- 1 cleaves and activates the precursor forms on IL-1 $\beta$ and L-18; both are subsequently secreted, and activate their receptors on target cells, resulting in the activation of proinflammatory pathways. 


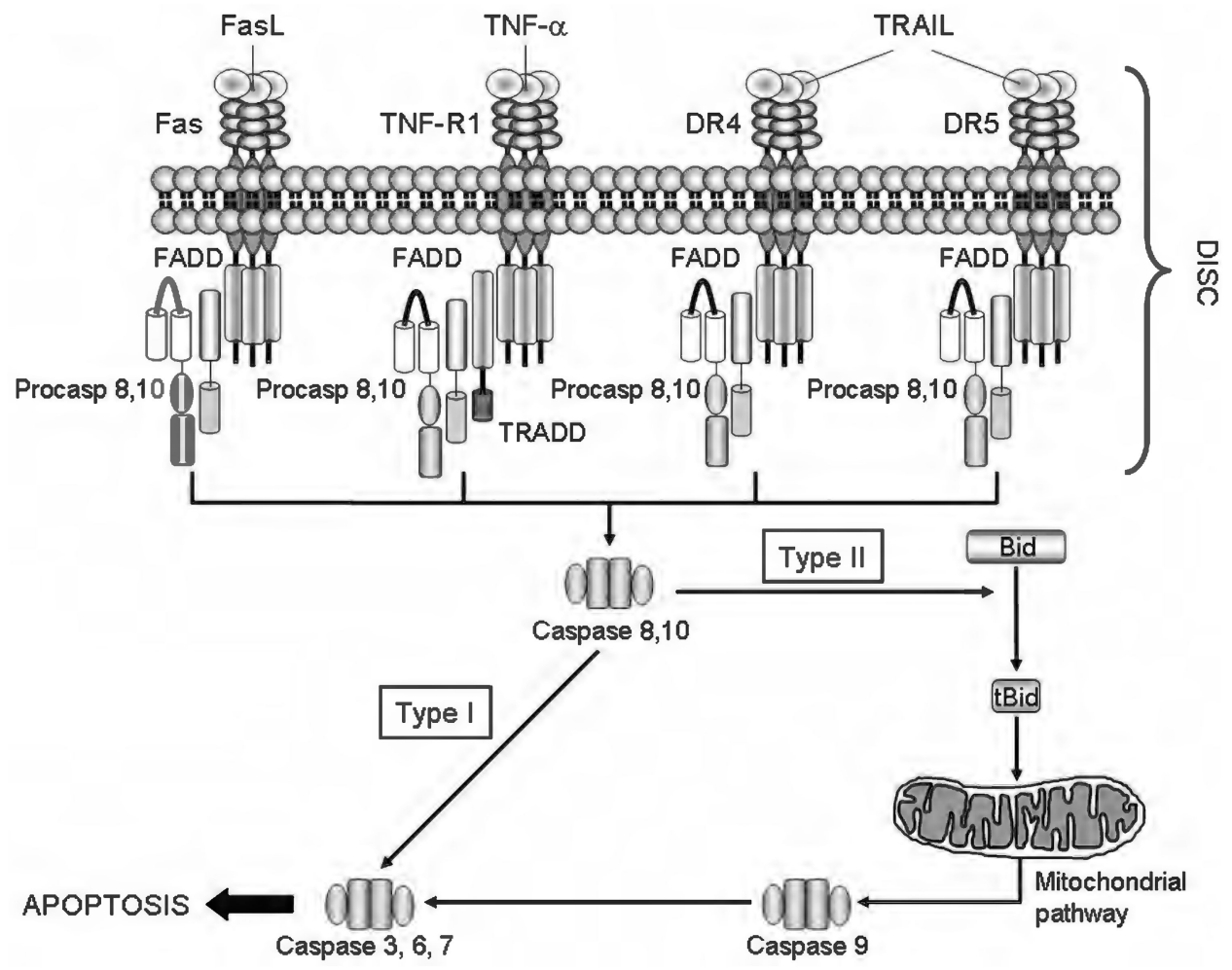

Figure 4.

The death receptors and the extrinsic pathway of apoptosis. Binding of a death ligand to its cognate receptor results in the recruitment of adaptor proteins, such as Fas-associated protein with death domain and Tumor necrosis factor receptor 1-associated death domain protein (TRADD), and procaspases 8 and/or 10, to form a multiprotein receptor complex named death inducing signaling complex (DISC). This complex provides a platform for caspase 8 and 10 to undergo autoactivation. In type I cells, active caspase 8/10 directly activate caspase 3 , an effector caspase, whereas in type II cells, caspase 8 (and, perhaps, caspase 10) cleaves the BH3-only protein Bid to generate truncated Bid (tBid). tBid, in turn, cooperates with $\mathrm{Bax}$ or Bak to induce mitochondrial outer membrane permeabilization and to initiate the mitochondrial pathway of apoptosis (see Figure 5 for details). 


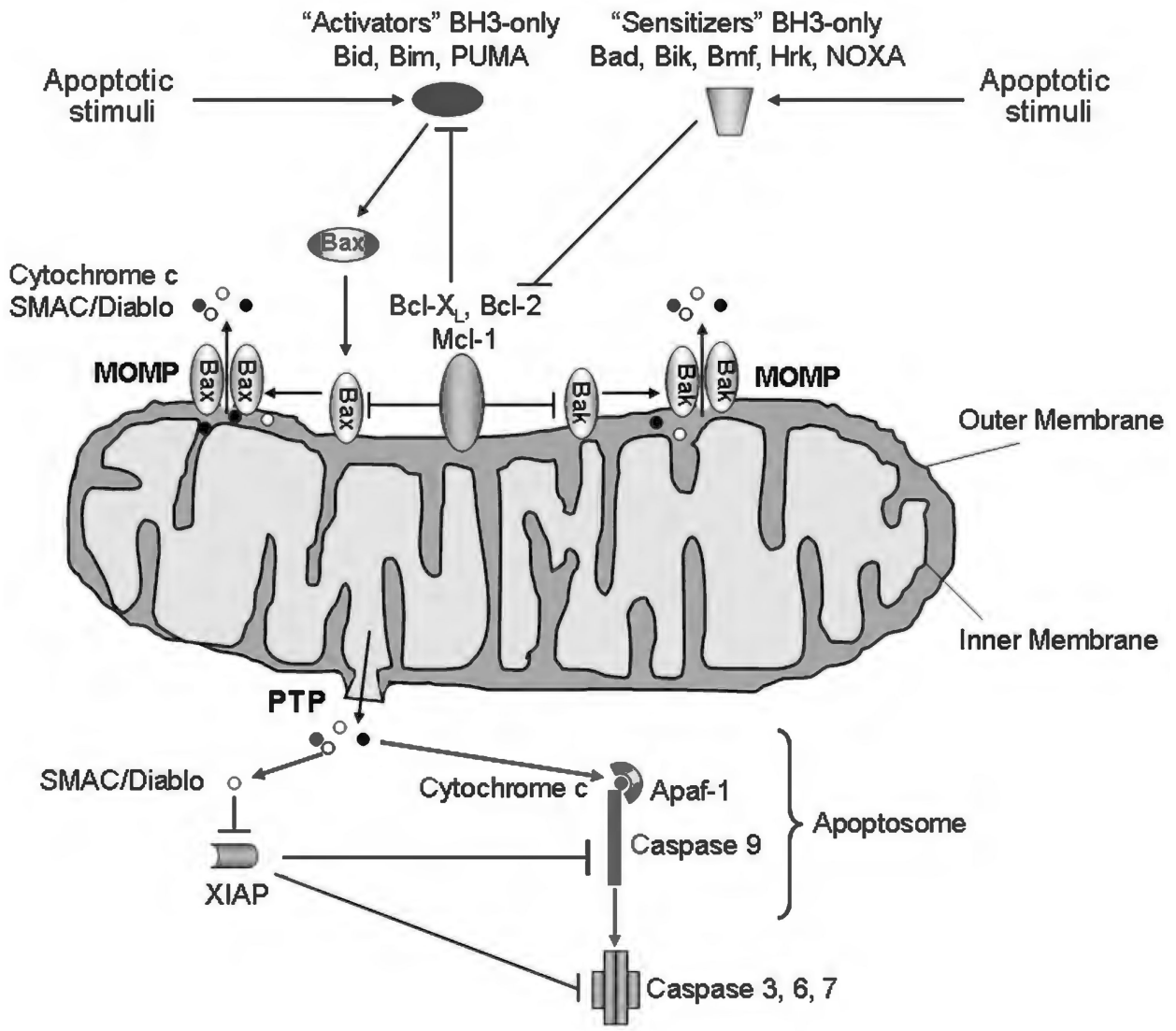

Figure 5.

The intrinsic pathway of apoptosis. Various stimuli, including UV and gamma-irradiation, endoplasmic reticulum (ER) stress, growth factor deprivation, and oxidative stress trigger the intrinsic pathway of apoptosis. This pathway requires the oligomerization of the proapoptotic members of the Bcl-2 family of protein Bax and/or Bak on the outer mitochondrial membrane, resulting in mitochondrial outer membrane permeabilization (MOMP) and release of apoptogenic factors. The oligomerization of Bax and Bak can be directly stimulated by the BH3-only proteins Bid, Bim, or PUMA (activators). Bax and Bak, as well as Bid, Bim and PUMA, are bound to and inhibited by the prosurvival Bcl-2 proteins, $\mathrm{Bcl}-2, \mathrm{Bcl}-\mathrm{x}_{\mathrm{L}}$, and $\mathrm{Mcl}-1$. The prosurvival function of these proteins can be repressed by the BH3-only proteins Bad, Bik, Hrk, Bmf, and NOXA (sensitizers), which displace Bid, Bim, and PUMA by binding to the prosurvival proteins. Release of Bid, Bim, and PUMA then allows activation of Bax and/or Bak. MOMP can also be achieved by the so-called mitochondrial permeability transition (MPT) initiated at the inner mitochondrial membrane through the opening of a multiprotein complex known as permeability transition pore (PTP). Several apoptogenic factors, including cytochrome $c$ and SMAC/DIABLO, are released from the mitochondrial intermembrane space into the cytosol as a consequence of MOMP. Cytochrome $c$ binds to the adaptor Apaf-1, and recruits procaspase-9 in a complex named apoptosome, which promotes the activation of caspase-9. Caspase-9, in turn, activates the effector caspases (caspase-3, 6, and 7). SMAC/DIABLO contributes to caspase activation by binding and inactivating the endogenous inhibitor of caspases $\mathrm{X}$-chromosome linked inhibitor of apoptosis protein. 


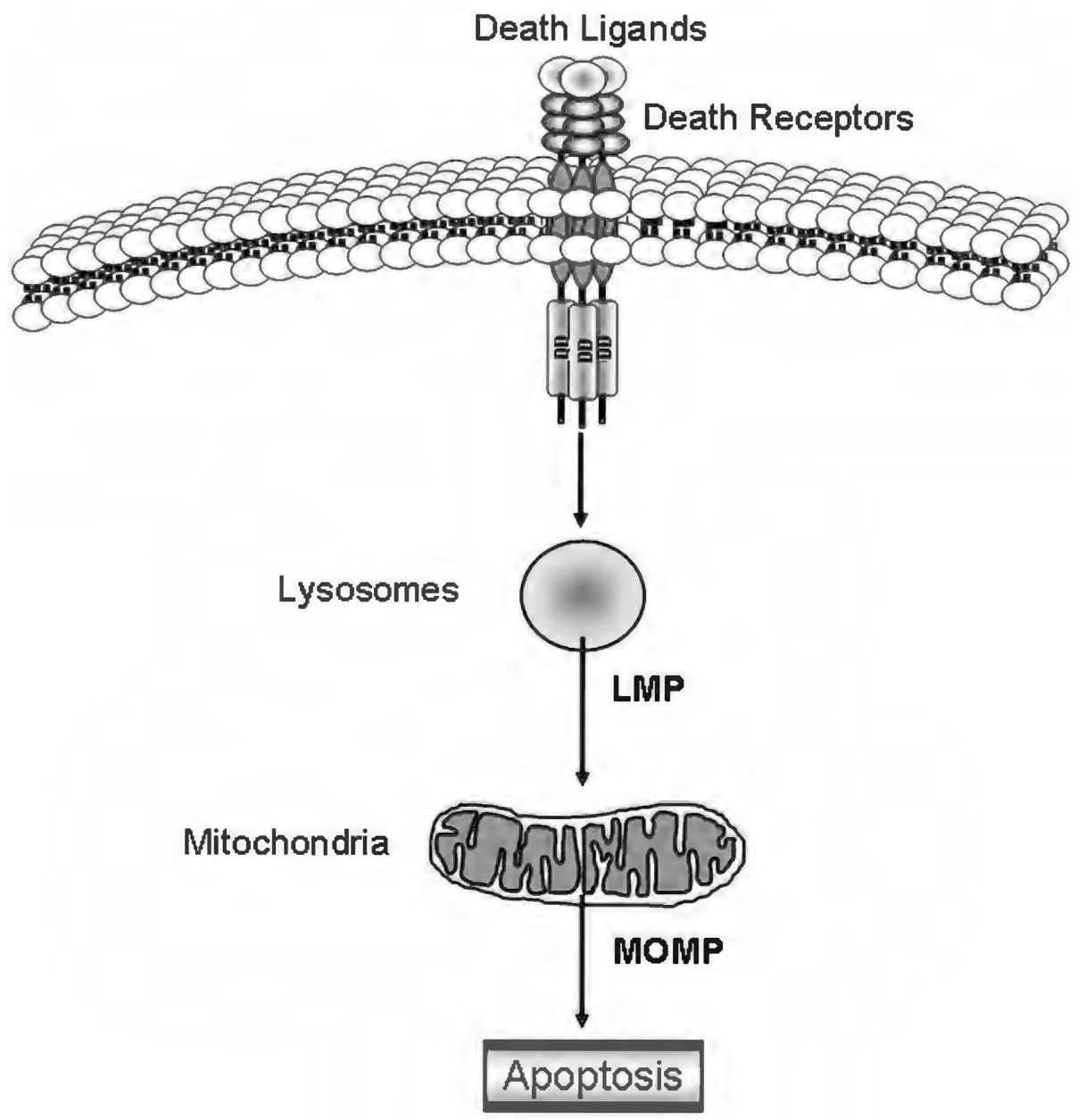

Figure 6.

The lysosomal pathway of apoptosis. In some cells, including hepatocytes and cholangiocytes, the binding of a death ligand to its cognate receptor results in early lysosomal membrane permeabilization associated with release of lysosomal enzymes into the cytosol. These lysosomal enzymes, and in particular the highly abundant lysosomal cathepsins, then trigger mitochondrial outer membrane permeabilization and mitochondrial dysfunction likely by cleaving and/or activating members of the Bcl-2 family. This apoptotic cascade as been referred to as the lysosomal pathway. 


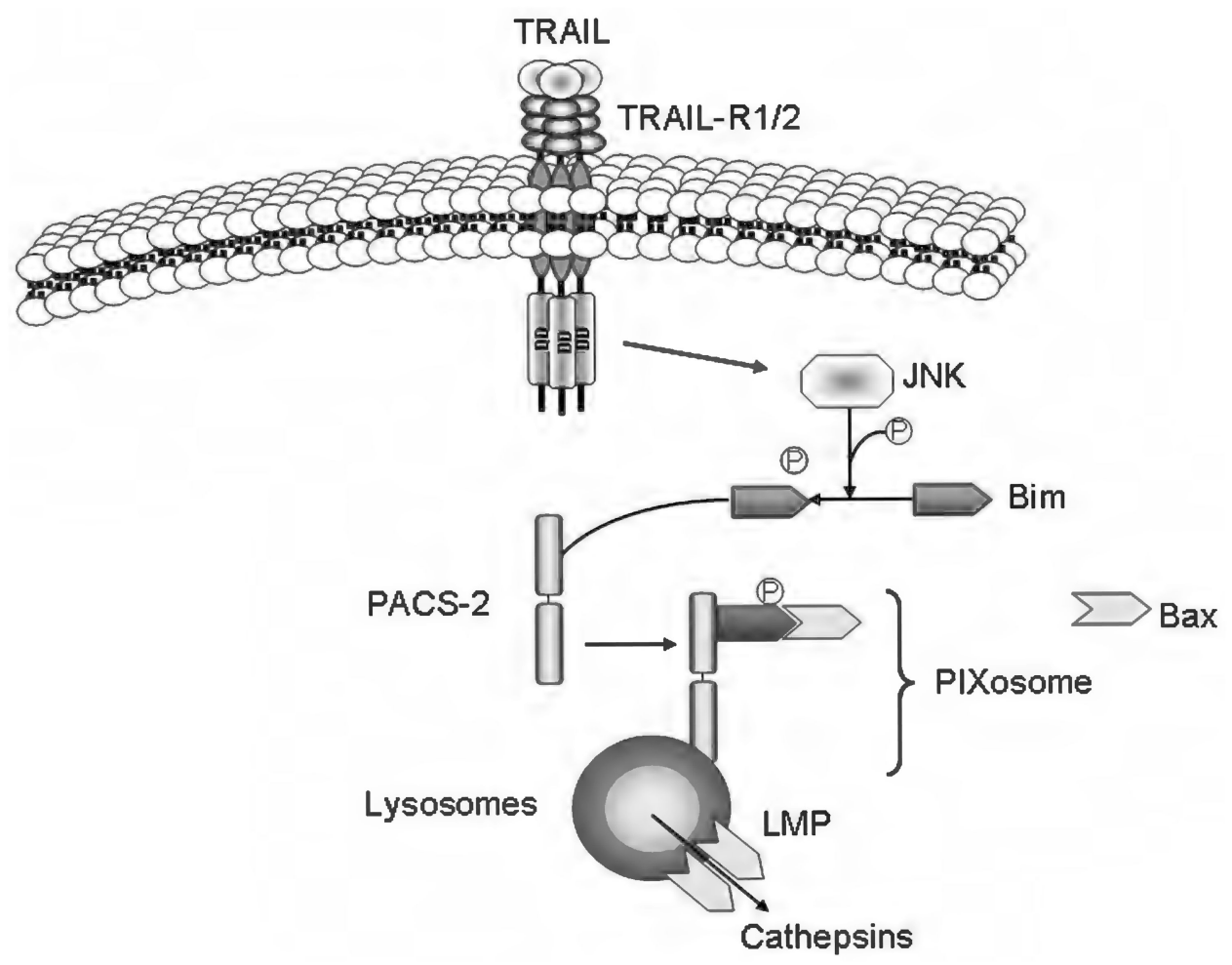

Figure 7.

Model of tumor necrosis factor-related apoptosis-inducing ligand (TRAIL)-induced lysosomal membrane permeabilization mediated by members of the Bcl-2 family of proteins. Binding of TRAIL to death receptor 5 results in c-jun N-terminal kinase-mediated phosphorylation of Bim and its release from the cytoskeleton. At the same time, phosphofurin acidic cluster sorting protein-2 (PACS-2) associates with the internalized receptor complex in the endosomal/lysosomal compartment and then binds the cytosolic Bim, promoting Bax association to the Bim:PACS-2 complex and subsequent Bax activation. This complex has been named the PIXosome (PACS-2:BIM:BAX). After translocating to the lysosomes, Bax inserts into the membrane, homo-oligomerizes and induces lysosomal membrane permeabilization. Cathepsins are released into the cytosol where they contribute to cell death. 


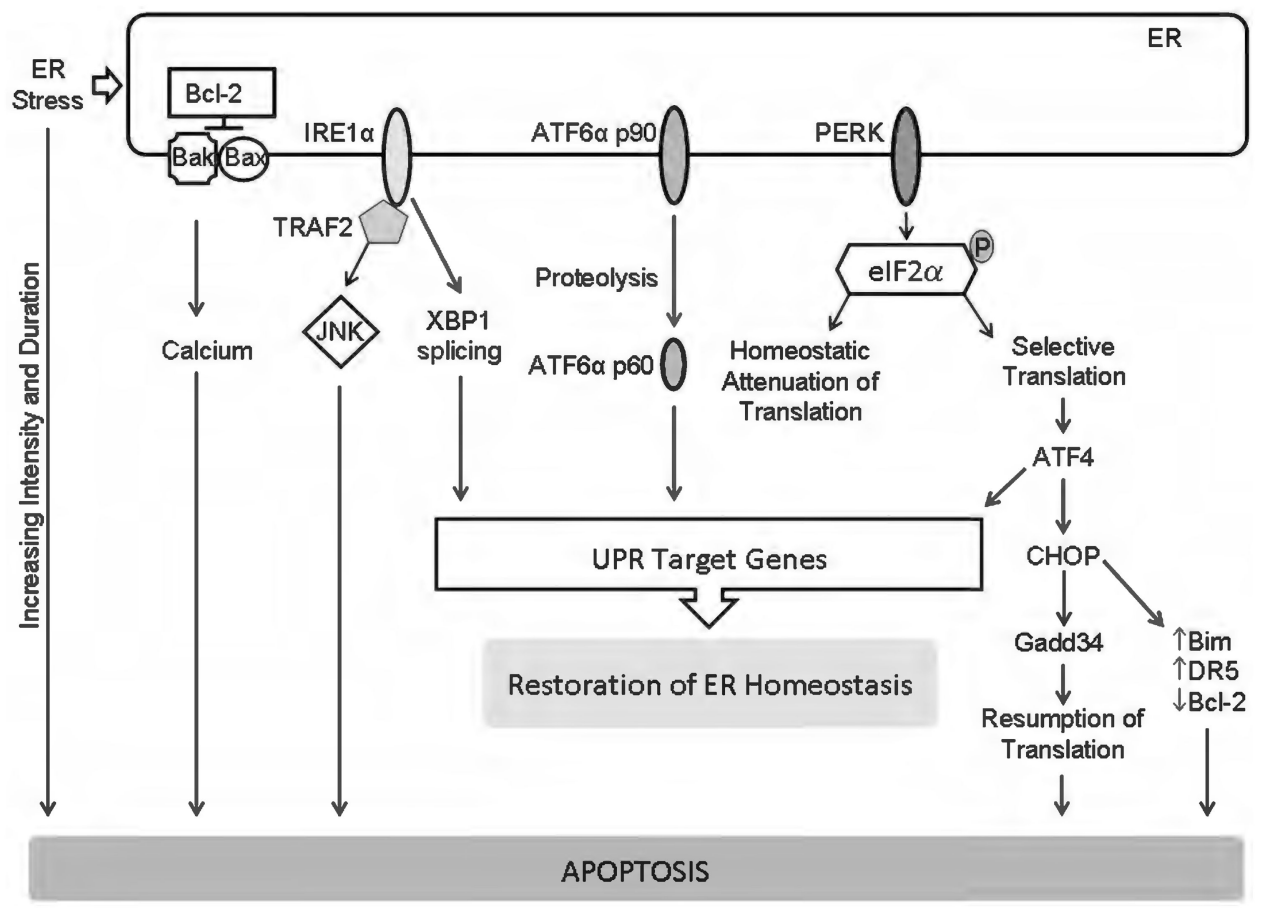

Figure 8.

Endoplasmic reticulum (ER) stress and apoptosis. ER stress activates, in parallel, three distinct ER-to-nucleus signaling pathways that are aimed at attenuating ER stress via activation of unfolded protein response (UPR) target genes with restoration of ER homeostasis. However, ER stress of increasing duration and intensity results in failure of restoration of homeostasis and apoptosis. The three canonical UPR mediators are ER transmembrane proteins; they are inositol-requiring protein 1a (IRE1a), activating transcription factor (ATF) 6a, and protein kinase RNA-like ER kinase (PERK). Active PERK phosphorylates eukaryotic translation initiation factor $2 a$ (eIF2a) leading to an attenuation of translation. This reduces the load of nascent proteins entering the ER. Selective translation of activating ATF4 also occurs. ATF4 promotes adaptation, but also transcriptionally activates $\mathrm{C} / \mathrm{EBP}$ homologous protein (CHOP). CHOP promotes ER stressinduced apoptosis via several pathways, including increasing the proapoptotic proteins Bim and death receptor 5 (DR5) and decreasing the antiapoptotic protein Bcl-2. IRE1a splices X box-binding protein 1 (XBP-1) mRNA to generate a transcription factor which leads to ER adaptation by activating a large number of UPR genes. The stress kinase, c-jun N-terminal kinase (JNK) is activated by IRE1a via the adaptor protein TNF receptor-associated factor 2 (TRAF2). Activating transcription factor $6 a$ (ATF6a) is proteolytically cleaved in the Golgi to generate a transcription factor which also drives expression of UPR target genes. Failure of restoration of ER homeostasis due to increasing intensity and duration of ER stress results in apoptosis. Some of the recognized mediators of ER stress-induced apoptosis are the transcription factor $\mathrm{CHOP}$ which can repress Bcl-2 expression, and increase expression of the proapoptotic proteins Bim and DR5. ER stress-induced apoptosis can also me mediated by ER calcium release, which can be regulated by Bax, Bak, and Bcl-2. The stress kinase JNK can also activate the intrinsic apoptosis machinery. 


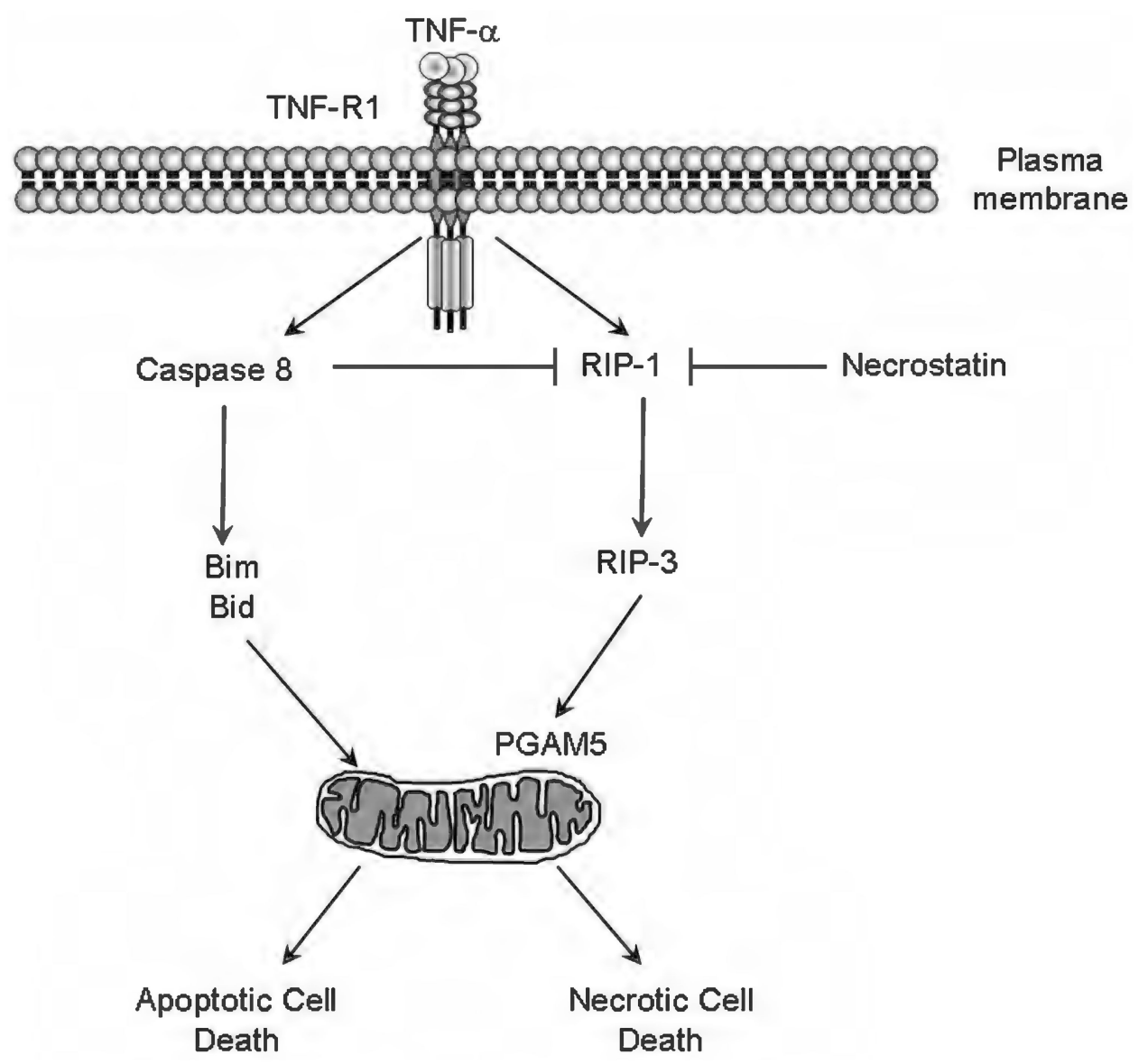

Figure 9.

TNF-a triggers both apoptotic and necrotic pathways. In conditions where activation of the transcription factor NF- $\mathrm{KB}$ is impaired, binding of TNF-a to TNF-R1 results in activation of caspase 8 , which triggers an apoptotic signaling cascade mediated by the $\mathrm{BH} 3$-only proteins $\mathrm{Bid}$ and Bim. Active caspase 8 also cleaves and inactivates the kinase RIP-1. When caspase 8 is inhibited and RIP-1 is not ubiquitinated, TNF-a stimulation induces RIP-1 association with RIP-3, promoting RIP-3 phosphorylation and activation. RIP-3, in turn, phosphorylates and activates the mitochondrial phosphatase phosphoglycerate mutase 5 (PGAM5), which promotes mitochondrial permeability transition and necroptosis. Necrostatin, a pharmacologic RIP-1 inhibitor, effectively prevents activation of the necroptotic signaling cascade. 

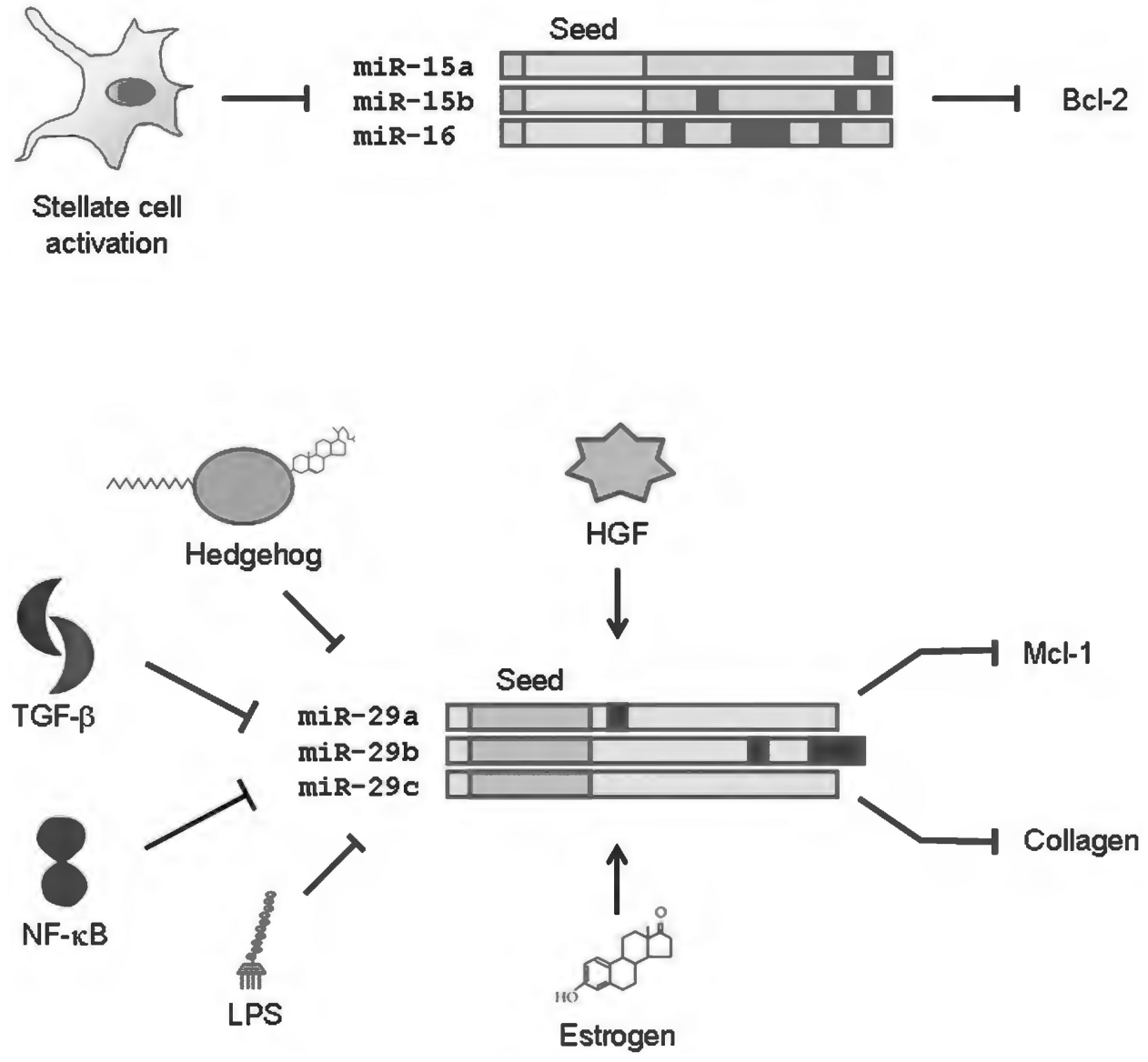

Figure 10.

Stabilization of microRNAs, like mRNAs, by adenylation. It is well known that mRNAs are stabilized by polyadenylation, a posttranscriptional modification that is dependent on multiple protein factors. For $p 53$, cytoplasmic polyadenylation element binding protein (CPEB) is necessary for polyadenylation. Similarly, microRNAs can be stabilized by modification at the $3^{\prime}$ terminus by monoadenylation; shown is the Gld-2-dependent adenylation of miR-122. Gld-2 mediated miR-122 stabilization results in increased miR-122, decreased CPEB, and less stabilization of p53. Conversely, decreased Gld-2 (or decreased miR-122) results in increased CPEB protein levels and activity, thus increasing p53 mRNA stability and promoting senescence. 


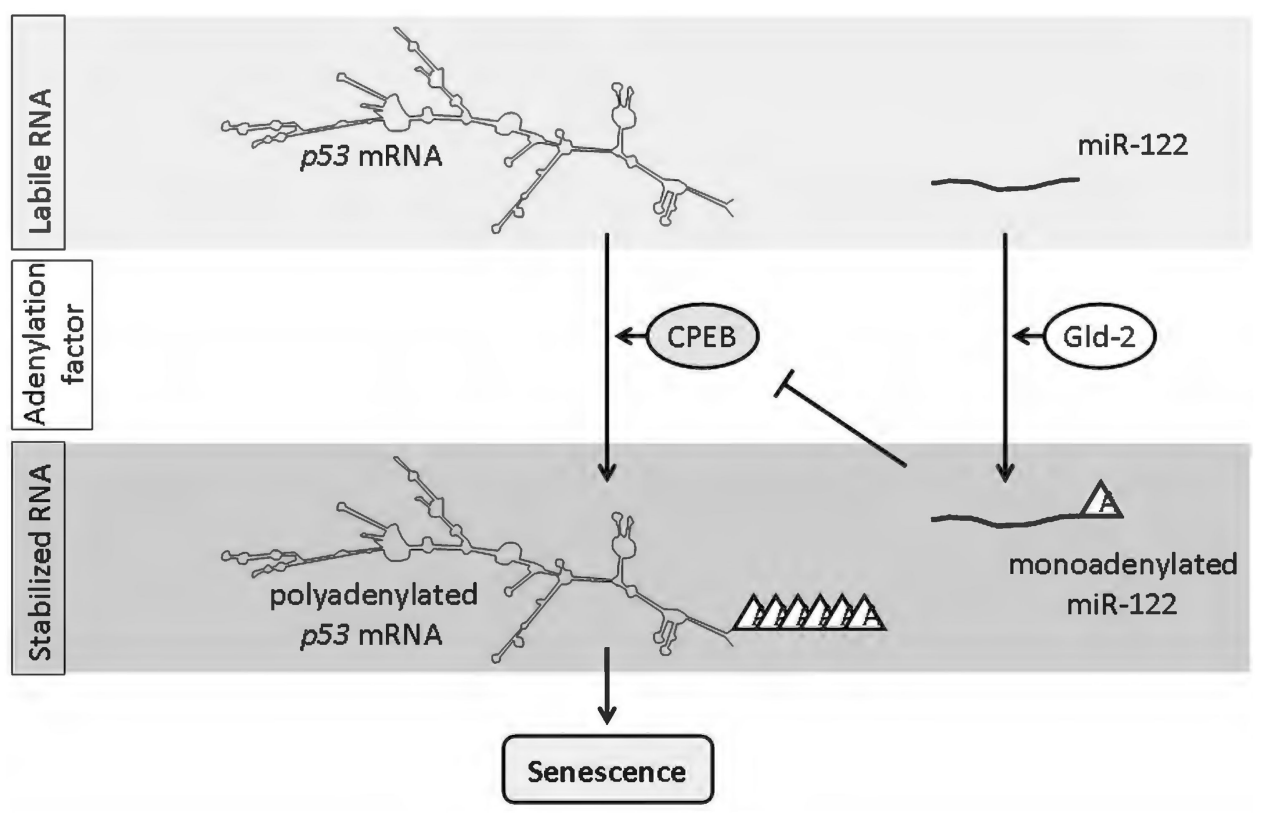

Figure 11.

Repression of microRNAs influences survival and function of liver cells, especially hepatic stellate cells. Among microRNAs altered in HSC activation or liver fibrogenesis are members of the miR-15 family and the miR-29 family. Upper: the miR-15 family contains three microRNAs which have identical seed sequences and scattered base differences in the $3^{\prime}$ end of the microRNA (indicated by colored blocks on the diagram). These microRNAs are decreased in culture-activated stellate cells, which permits derepression of Bcl-2, promoting cell survival. Lower: the miR-29 family also contains three family members with seed identity and a few base differences in the $3^{\prime}$ end. Several studies have demonstrated molecular signals that either inhibit [Hedgehog, transforming growth factor (TGF)- $\beta$, nuclear factor kappa B (NF- $\mathrm{KB}$ ), and lipopolysaccharide (LPS)] or activate [hepatocyte growth factor (HGF) and estrogen] miR-29 expression. Decreased miR-29 allows excess collagen expression, promoting fibrosis, and excess Mcl-1, promoting cell survival. 


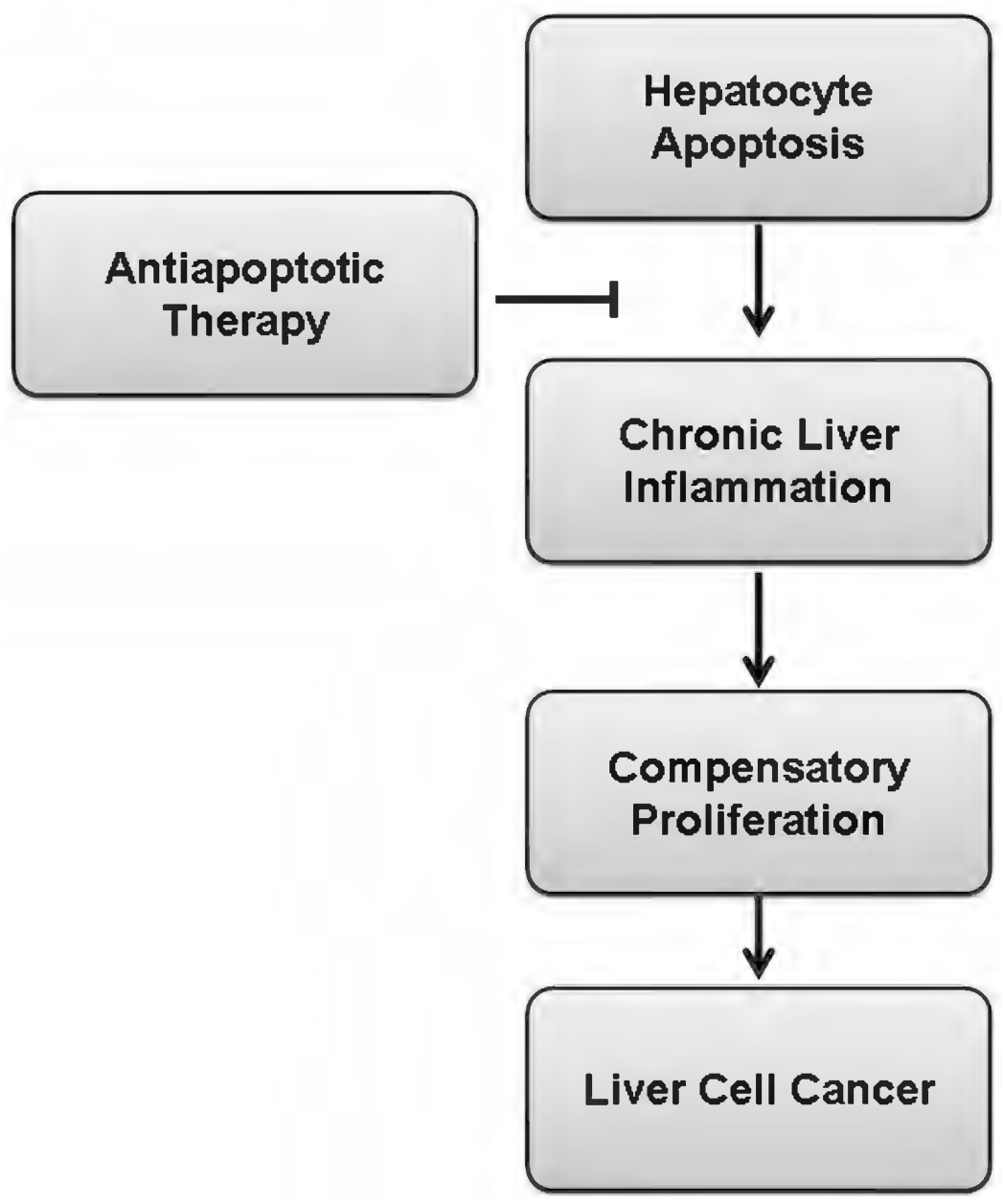

Figure 12.

Model of liver disease progression. In pathologic conditions, persistent hepatocyte apoptosis promotes chronic liver inflammation and associated compensatory cellular proliferation, increasing the risk of carcinogenesis in the liver. Inhibition of apoptosis in these conditions should protect against the development of liver cancer. 